\title{
APLICAÇÃO LOCALIZADA DE DEFENSIVOS BASEADA NA VARIABILIDADE ESPACIAL DAS PLANTAS DANINHAS
}

\section{FÁBIO HENRIQUE ROJO BAIO}

\begin{abstract}
Dissertação apresentada à Escola Superior de Agricultura "Luiz de Queiroz", Universidade de São Paulo, para obtenção do título de Mestre em Agronomia, Área de concentração: Máquinas Agrícolas.
\end{abstract}

P I R A C I C A B A

Estado de São Paulo - Brasil

Dezembro - 2001 


\title{
APLICAÇÃO LOCALIZADA DE DEFENSIVOS BASEADA NA VARIABILIDADE ESPACIAL DAS PLANTAS DANINHAS
}

\author{
FÁBIO HENRIQUE ROJO BAIO
}

Engenheiro Agrônomo

Orientador: Prof. Titular LUIZ ANTONIO BALASTREIRE

\begin{abstract}
Dissertação apresentada à Escola Superior de Agricultura "Luiz de Queiroz", Universidade de São Paulo, para obtenção do título de Mestre em Agronomia, Área de concentração: Máquinas Agrícolas.
\end{abstract}

P I R A C I C A B A

Estado de São Paulo - Brasil

Dezembro - 2001 


\title{
Dados Internacionais de Catalogação na Publicação (CIP) DIVISÃO DE BIBLIOTECA E DOCUMENTAÇÃO - ESALQ/USP
}

\author{
Baio, Fábio Henrique Rojo \\ Aplicação localizada de defensivos baseada na variabilidade espacial das plantas \\ daninhas / Fábio Henrique Rojo Baio. - P Piracicaba, 2001. \\ 113 p. : il. (Acompanha CD-ROM) \\ Dissertação (mestrado) - - Escola Superior de Agricultura Luiz de Queiroz, 2001. \\ Bibliografia.
}

1. Agricultura 2. Herbicidas 3. Instrumentos de precisăo 4. Mapeamento do solo 5. Plantas daninhas 6. Pulverizadores I. Titulo

CDD 632.58 


\section{AGRADECIMENTOS}

A Deus, pela vida e pela oportunidade de crescer como pessoa e como profissional.

Ao Professor Titular Luiz Antonio Balastreire pela orientação e confiança em mim depositada.

À FAPESP, que deu o suporte financeiro para a execução deste trabalho.

À Escola Superior de Agricultura "Luiz de Queiroz" pela formação profissional desde a minha graduação.

Aos Professores Tomaz C. Rípoli, Ulisses R. Antuniassi e Walter F. Molina Jr. pelas valiosas sugestões e a todos os Professores do Departamento de Engenharia Rural que contribuíram para a minha formação e enriquecimento profissional.

A todos os funcionários do Departamento de Engenharia Rural, em especial ao Juarez Reno Amaral, pelo apoio durante a realização deste trabalho.

Ao amigo Adriano Vecchiatti Lupinacci pela paciência e companheirismo. Aos amigos Domingos G. P. Cerri, Júlio César D. M. Esquerdo e Juliano C. G. Leal pelo incentivo e colaboração. Aos meus colegas discentes pelo apoio e amizade durante o curso.

Aos irmãos Lúcio e José Roberto Borges, proprietários da Fazenda Lagoa Velha, por terem cedido a área para a realização deste trabalho.

À Empresa Máquinas Agrícolas Jacto por ter cedido o equipamento utilizado no presente trabalho.

À Fundação Shunji Nishimura de Tecnologia por ter realizado as análises químicas de solo e pela formação profissional que recebi quando lá passei.

À Empresa Santiago \& Cintra por ter emprestado o programa Farm Site Mate utilizado neste trabalho. 
À Empresa Monsanto do Brasil pelo patrocínio do herbicida utilizado.

À minha tia Sueli Baio Bonfim pela valiosa contribuição na revisão do presente trabalho.

Finalmente aos meus pais, que me incentivaram, dedico. 


\section{SUMÁRIO}

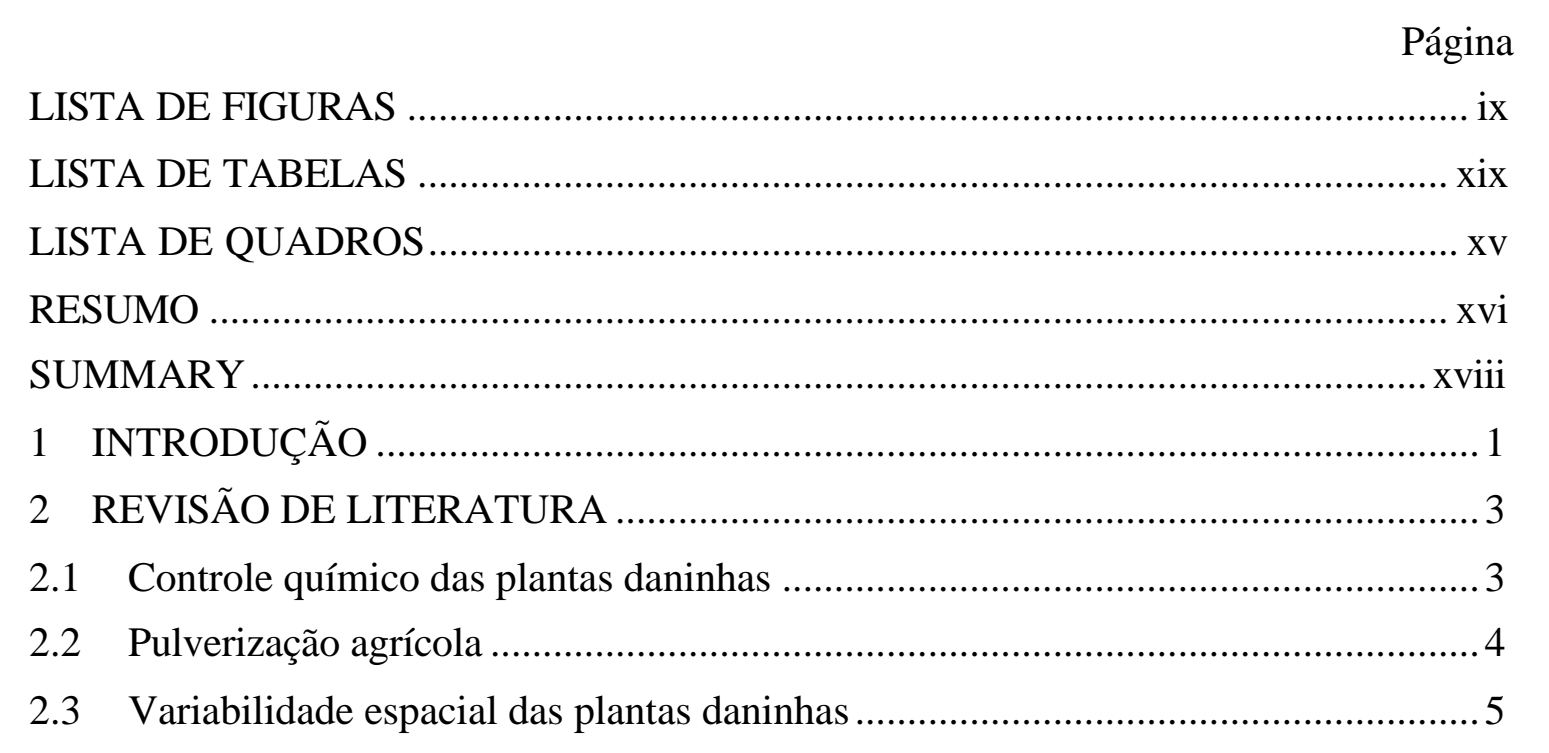

2.4 Mapeamento da variabilidade espacial das plantas daninhas .............................. 6

2.4.1 Mapeamento de plantas daninhas por amostragens sistemáticas....................... 7

2.4.2 Mapeamento de plantas daninhas com auxilio de cartas cartográficas ...............9

2.4.3 Mapeamento de plantas daninhas por técnicas de sensoriamento remoto ..........9

2.4.4 Mapeamento de plantas daninhas pelo método linear .................................... 11

2.4.5 Mapeamento de plantas daninhas pelo método do contorno das manchas de ocorrência .................................................................................... 12

2.5 Mapeamento da fertilidade do solo ............................................................ 12

2.6 Correlação entre mapas de plantas daninhas e atributos do solo .......................... 14

2.7 Sistema de Posicionamento Global - GPS .................................................. 15

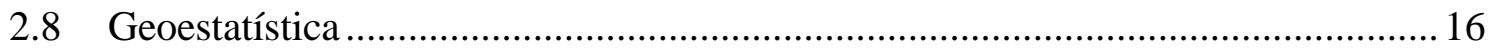

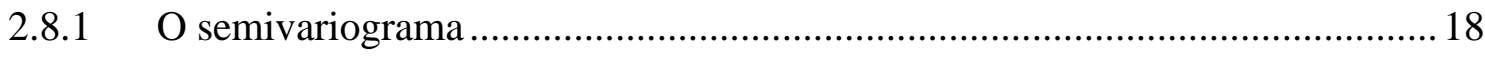

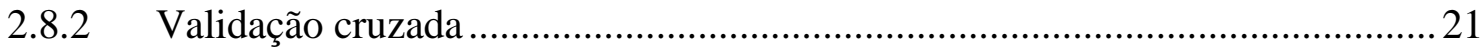

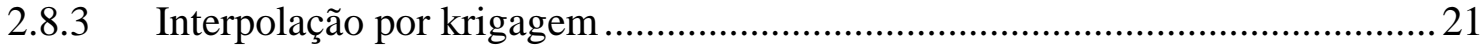


2.9 Sistemas de Informações Geográficas - SIG ................................................. 22

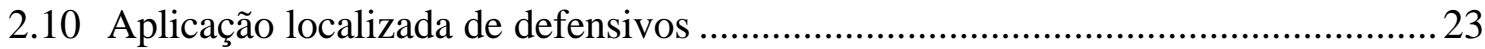

2.10.1 Aplicação localizada baseada no conceito do controle de plantas daninhas

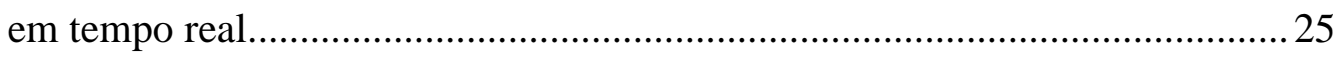

2.10.2 Aplicação localizada baseada no conceito do mapeamento............................26

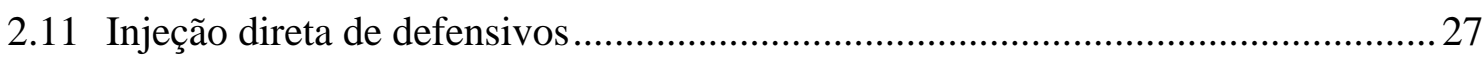

2.11.1 Componentes principais de um equipamento para injeção direta de

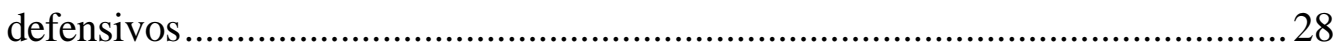

2.11.2 Requisitos técnicos dos equipamentos para injeção direta de defensivos ........30

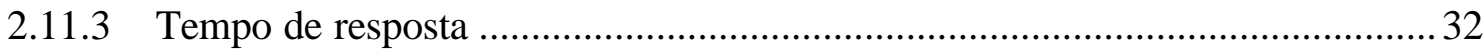

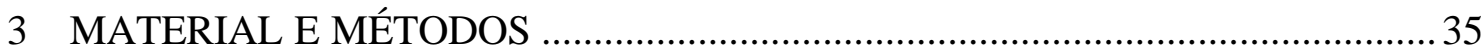

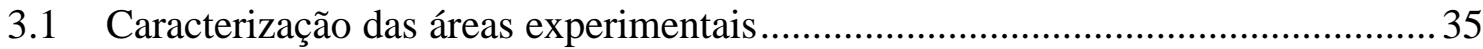

3.2 Sistema de Posicionamento Global - GPS ....................................................... 38

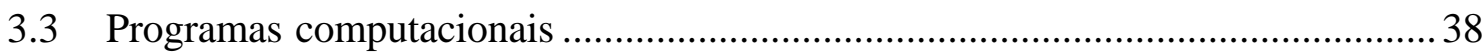

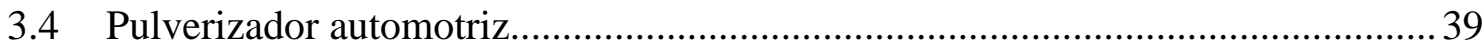

3.5 Sistema de injeção direta de defensivos ................................................... 40

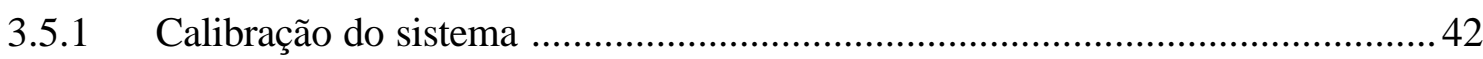

3.5.2 Pré-ensaio para a verificação do funcionamento do sistema .......................... 42

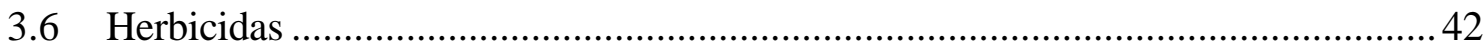

3.7 Ensaio para determinação do tempo de resposta do sistema .............................. 43

3.7.1 Aplicação do defensivo segundo o mapa de prescrição para determinação

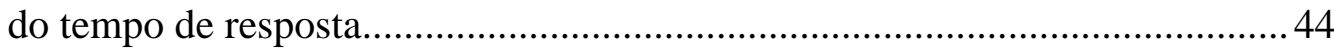

3.7.2 Cálculo do tempo de resposta do sistema ................................................ 45

3.8 Mapeamento de plantas daninhas e dos atributos da fertilidade do solo .............. 46

3.8.1 Mapeamento de plantas daninhas ........................................................ 47

3.8.1.1 Mapeamento de plantas daninhas pela metodologia das amostragens

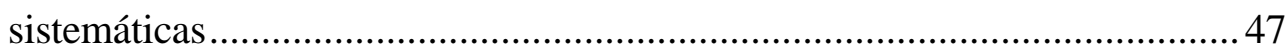

3.8.1.2 Mapeamento de plantas daninhas pela metodologia do contorno das manchas de ocorrência ....................................................................... 48

3.8.2 Mapeamento dos atributos da fertilidade do solo ....................................... 49

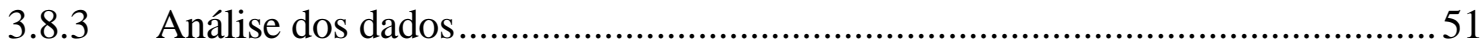

3.8.3.1 Análise estatística dos dados amostrados.............................................. 51 
3.8.3.2 Análise geoestatística dos dados amostrados.......................................... 52

3.8.3.3 Interpolação dos dados amostrados ..................................................... 53

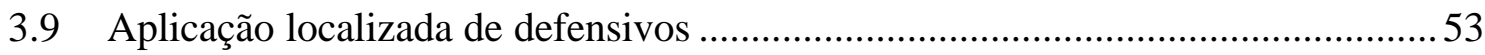

3.9.1 Elaboração dos mapas de prescrição......................................................... 53

3.9.2 Execução da aplicação localizada de defensivos .........................................54

3.9.3 Geração e correção do mapa da aplicação ................................................... 55

3.9.4 Verificação do resultado da aplicação localizada .........................................55

3.10 Comparação entre as metodologias utilizadas para o mapeamento de plantas

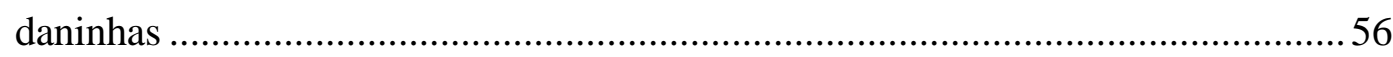

3.11 Correlação entre os mapas de plantas daninhas e dos atributos da fertilidade

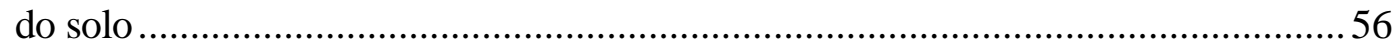

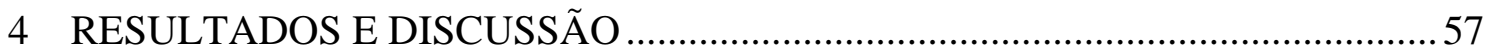

4.1 Tempo de resposta do equipamento utilizado .................................................57

4.1.1 Determinação do tempo de resposta do equipamento para aplicação

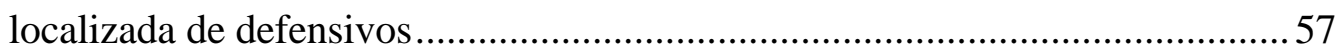

4.1.2 Avaliação da metodologia utilizada para a determinação do tempo de

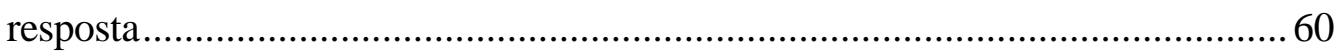

4.2 Análise dos dados obtidos pelas metodologias das amostragens de plantas daninhas e dos atributos da fertilidade do solo ............................................. 60

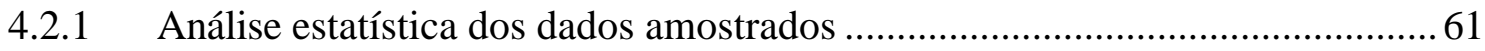

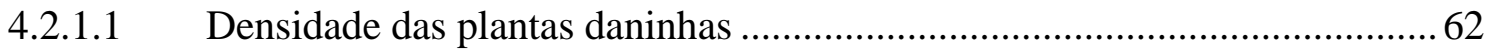

4.2.1.2 Estágio de desenvolvimento das plantas daninhas ................................... 63

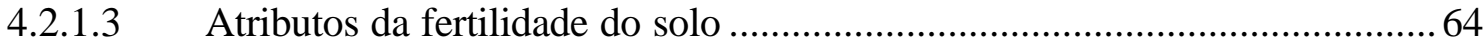

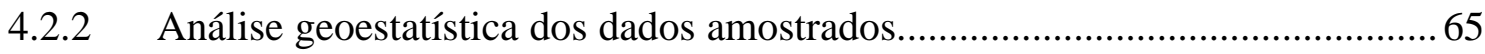

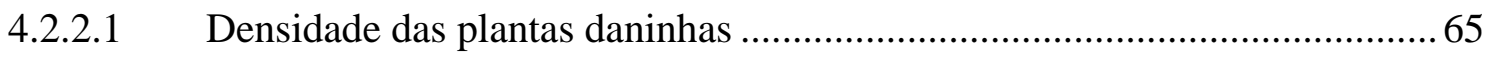

4.2.2.2 Estágio de desenvo lvimento das plantas daninhas ....................................66

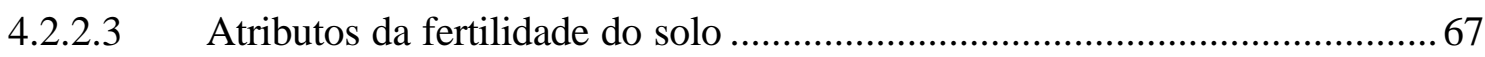

4.3 Mapas de plantas daninhas e dos atributos da fertilidade do solo .......................69

4.3.1 Mapas de plantas daninhas obtidos pela metodologia das amostragens

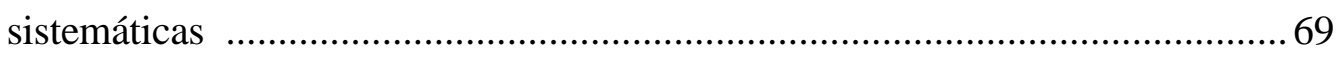

4.3.2 Mapas de plantas daninhas obtidos pela metodologia do contorno das manchas de ocorrência 


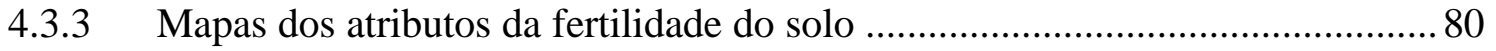

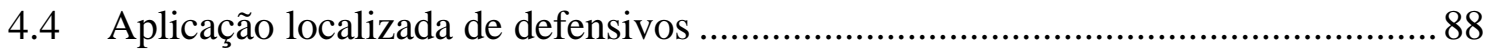

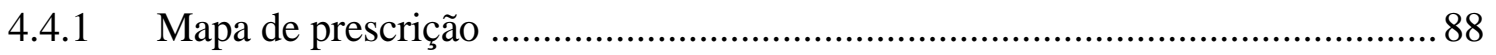

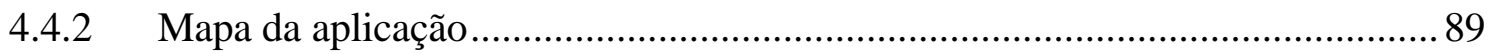

4.4.3 Verificação do controle das plantas daninhas e economia do herbicida alcançada pela utilização do sistema.......................................................... 94

4.5 Comparação entre as metodologias para o mapeamento de plantas daninhas

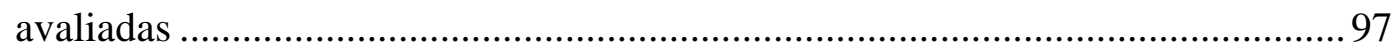

4.6 Análise da correlação da variabilidade espacial entre as espécies de plantas daninhas e os atributos da fertilidade do solo .................................................. 99

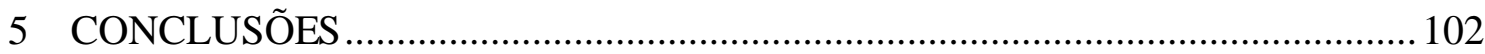

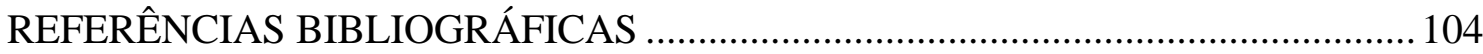




\section{LISTA DE FIGURAS}

Página

1 Semivariograma experimental e modelo teórico. .............................................. 19

2 O semivariograma típico e seus componentes. .................................................. 20

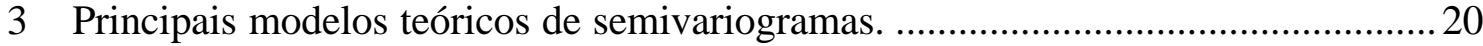

4 Esquema de um sensor para a aplicação localizada de herbicidas em tempo

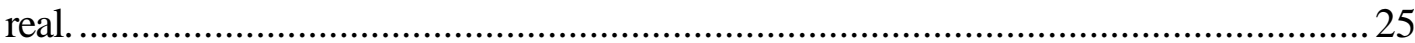

5 Componentes principais de um equipamento para aplicação localizada por injeção direta de defensivos. ........................................................................ 28

6 Curva de dose-resposta para uma típica combinação entre o incremento do herbicida aplicado (\%) e o aumento das plantas daninhas controladas (\%).

7 Simulação da distância percorrida pelo pulverizador (D1 + D2) do instante em que houve uma ordem para o início da aplicação (T0) até o instante onde se observa o equilíbrio da concentração do defensivo em toda a extensão da barra (T2).

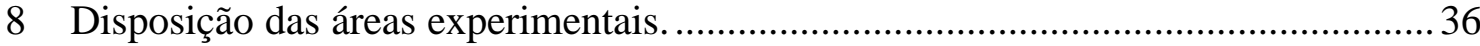

9 Ilustração da área experimental onde foi realizado o ensaio para determinação do tempo de resposta do equipamento para aplicação localizada de defensivos...... 37

10 Ilustrações da área experimental onde foram realizados os mapeamentos de plantas daninhas, o mapeamento de fertilidade e a aplicação localizada de defensivos: (a) região onde havia uma maior infestação de plantas daninhas e (b) região onde havia uma menor infestação de plantas daninhas.

11 Vistas lateral (a) e traseira (b) do protótipo do pulverizador automotriz utilizado neste estudo. 
12 Ilustração das bombas peristálticas (a), dos reservatórios de defensivos (b), do controlador microprocessado (c) e vista geral do sistema eletrônico com o controlador microporcessado (1), a interface (2) e o computador portátil (3) (d).

13 Mapa de prescrição para o ensaio do tempo de resposta do equipamento para aplicação localizada de defensivos e trajeto planejado do pulverizador materializado pelos pontos referenciais.

14 Configuração da grade amostral para o mapeamento de plantas daninhas pela metodologia das amostragens sistemáticas.

15 Configuração da grade amostral para o mapeamento de atributos da fertilidade do solo por amostragens sistemáticas.

16 Sobreposição do mapa de prescrição para a realização do ensaio do tempo de resposta, pontos referenciais e mancha mapeada onde houve a ação do herbicida.

17 Tempo de resposta do sistema de injeção direta de defensivos montado sobre o pulverizador automotriz para toda a extensão de sua barra, desde o instante $\mathrm{T}=0$, que representa o momento no qual a mudança da dose do herbicida foi solicitada $\left(0\right.$ 1.ha ${ }^{-1}$ para 2 1.ha $\left.{ }^{-1}\right)$.

18 Transição entre a mancha controlada de milheto e a área não controlada no ensaio para determinação do tempo de resposta.

19 Comparação entre as porcentagens dos pontos amostrais onde as espécies de plantas daninhas mapeadas estavam presentes, separadas por estágios de desenvolvimento.

20 Ilustração da variabilidade espacial do estágio de desenvolvimento da planta daninha buva.

21 Ilustração da variabilidade espacial da densidade (plantas.m²) de ocorrência da planta daninha buva.

22 Ilustração da variabilidade espacial do estágio de desenvolvimento da planta daninha capim amargoso.

23 Ilustração da variabilidade espacial da densidade (plantas.m² ${ }^{-2}$ ) de ocorrência da planta daninha capim amargoso. 
24 Ilustração da variabilidade espacial do estágio de desenvolvimento da planta daninha capim carrapicho.

25 Ilustração da variabilidade espacial da densidade (plantas.m²) de ocorrência da planta daninha capim carrapicho.

26 Ilustração da variabilidade espacial do estágio de desenvolvimento da planta daninha leiteiro

27 Ilustração da variabilidade espacial da densidade (plantas.m² ${ }^{-2}$ ) de ocorrência da planta daninha leiteiro.

28 Ilustração da variabilidade espacial do estágio de desenvolvimento da planta daninha macelinha.

29 Ilustração da variabilidade espacial da densidade (plantas. $\mathrm{m}^{-2}$ ) de ocorrência da planta daninha macelinha.

30 Ilustração da variabilidade espacial do estágio de desenvolvimento da planta daninha picão preto.

31 Ilustração da variabilidade espacial da densidade (plantas.m²) de ocorrência da planta daninha picão preto.

32 Ilustração da variabilidade espacial da planta daninha buva mapeada pela metodologia do contorno das manchas de ocorrência.

33 Ilustração da variabilidade espacial da planta daninha capim amargoso mapeada pela metodologia do contorno das manchas de ocorrência. 77

34 Ilustração da variabilidade espacial da planta daninha capim carrapicho mapeada pela metodologia do contorno das manchas de ocorrência.

35 Ilustração da variabilidade espacial da planta daninha leiteiro mapeada pela metodologia do contorno das manchas de ocorrência. 78

36 Ilustração da variabilidade espacial da planta daninha macelinha mapeada pela metodologia do contorno das manchas de ocorrência.

37 Ilustração da variabilidade espacial da planta daninha picão preto mapeada pela metodologia do contorno das manchas de ocorrência.

38 Ilustração da variabilidade espacial do $\mathrm{pH} \mathrm{CaCb}$ do solo na área experimental. ..... 80

39 Ilustração da variabilidade espacial da Capacidade de Troca de Cátions do solo na área experimental. 
40 Ilustração da variabilidade espacial da Saturação por Bases na área

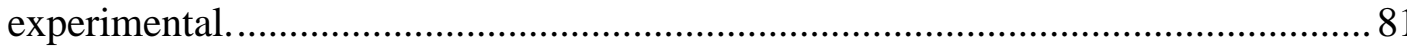

41 Ilustração da variabilidade espacial do teor da Matéria Orgânica do solo na área experimental.

42 Ilustração da variabilidade espacial do teor de Fósforo do solo na área experimental

43 Ilustração da variabilidade espacial do teor de Potássio do solo na área experimental

44 Ilustração da variabilidade espacial teor do de Cálcio do solo na área experimental

45 Ilustração da variabilidade espacial do teor de Magnésio do solo na área experimental.

46 Ilustração da variabilidade espacial do teor de Enxofre do solo na área experimental

47 Ilustração da variabilidade espacial do teor de Ferro do solo na área experimental

48 Ilustração da variabilidade espacial do teor de Cobre do solo na área experimental

49 Ilustração da variabilidade espacial do teor de Manganês do solo na área experimental

50 Ilustração da variabilidade espacial do teor de Zinco do solo na área experimental.

51 Ilustração da variabilidade espacial do teor de Boro do solo na área experimental

52 Mapa de prescrição utilizado na aplicação localizada do defensivo........................ 88

53 Sobreposição do mapa da aplicação sem correção ao mapa de prescrição............... 90

54 Sobreposição do mapa da aplicação corrigido ao mapa de prescrição. ................... 91

55 Erro de trajetória do pulverizador durante a aplicação promovendo o surgimento de pontos no mapa da aplicação com dosagem diferente da recomendada no mapa de prescrição.

56 Bordadura ("buffer") ao redor do perímetro da área experimental. 
57 Ilustração do controle das plantas daninhas (manchas claras) em duas regiões

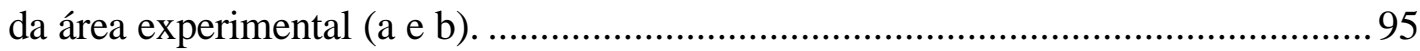

58 Ilustração da área mapeada onde as plantas daninhas não foram controladas

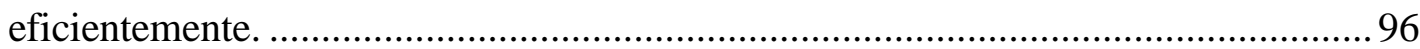

59 Sobreposição dos mapas ilustrativos da variabilidade espacial do capim carrapicho obtidos pelas metodologias de mapeamento de plantas daninhas por amostragens sistemáticas e pelo contorno das manchas de ocorrência. 


\section{LISTA DE TABELAS}

Página

1 Resultados da análise estatística descritiva realizada para os dados da variável densidade das plantas daninhas (plantas. $\mathrm{m}^{-2}$ ) para as quatro espécies mapeadas pelo método das amostragens sistemáticas. 62

2 Resultados da análise estatística descritiva realizada para os dados da variável estágio de desenvolvimento do mapeamento de plantas daninhas pelo método das amostragens sistemáticas.

3 Resultados da análise estatística descritiva realizada para as variáveis do mapeamento dos atributos da fertilidade do solo.

4 Resultados da análise geoestatística para os dados da variável densidade (plantas. $\mathrm{m}^{-2}$ ) para as quatro espécies de plantas daninhas mapeadas pelo método das amostragens sistemáticas.

5 Resultados da análise geoestatística realizada para os dados da variável estágio de desenvolvimento do mapeamento de plantas daninhas pelo método das amostragens sistemáticas.

6 Resultados da análise geoestatística para as variáveis do mapeamento dos atributos da fertilidade do solo.

7 Comparação entre as metodologias de mapeamento de plantas daninhas avaliadas neste estudo.

8 Coeficientes de Correlação de Pearson entre as variáveis do mapeamento de fertilidade do solo e do mapeamento de plantas daninhas. 


\section{LISTA DE QUADROS}

Página

1 Exemplos de grades e de áreas amostrais utilizadas por alguns autores para a realização de mapeamentos de plantas daninhas por amostragens sistemáticas.........8

2 Nome comum, nome científico e código internacional WSSA ("Weed Science Society of America") das espécies de plantas daninhas mapeadas pelos métodos de mapeamento por amostragens sistemáticas e pelo contorno das

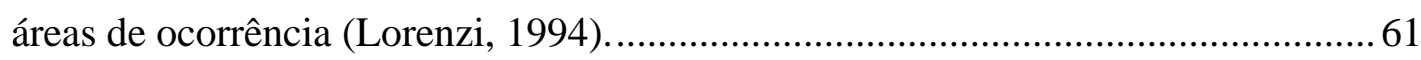




\section{APLICAÇÃO LOCALIZADA DE DEFENSIVOS BASEADA NA VARIABILIDADE ESPACIAL DAS PLANTAS DANINHAS}

Autor: Fábio Henrique Rojo Baio

Orientador: Prof. Titular Luiz Antonio Balastreire

\section{RESUMO}

As plantas daninhas apresentam variabilidade espacial no campo. Esta variabilidade espacial permite o mapeamento e o controle destas plantas de acordo com a necessidade de cada local. Este trabalho teve por objetivos o desenvolvimento e a avaliação de uma metodologia para determinação do tempo de resposta de um equipamento para aplicação localizada de defensivos, a avaliação da eficiência e da economia de herbicida alcançada pela utilização deste sistema, a comparação de duas metodologias para o mapeamento de plantas daninhas e o estudo da correlação da variabilidade espacial entre espécies de plantas daninhas e atributos da fertilidade do solo. A metodologia avaliada para determinação do tempo de resposta de um equipamento para aplicação localizada de defensivos mostrourse prática e rápida. $\mathrm{O}$ tempo de resposta do equipamento avaliado foi de 28 segundos. Foi possível a identificação e o mapeamento de seis espécies de plantas daninhas na área experimental por duas metodologias distintas. A metodologia de mapeamento de plantas daninhas por amostragens sistemáticas se mostrou muito demorada em campo, pouco prática e exigiu um maior tempo para a obtenção dos mapas de plantas daninhas. A metodologia de mapeamento de plantas daninhas pelo contorno das manchas de ocorrência mostrou-se 
rápida para o levantamento dos dados em campo e para a elaboração dos mapas resultantes. Porém, se mostrou uma metodologia subjetiva. Foi possível a criação de um mapa de prescrição com quatro dosagens diferentes de herbicida baseado na variabilidade espacial das espécies de plantas daninhas mapeadas. O mapa da aplicação foi coerente com o mapa de prescrição. As plantas daninhas mapeadas foram controladas eficientemente. O sistema para aplicação localizada de defensivos permitiu uma economia de $31,6 \%$ de herbicida, quando comparado à aplicação em área total. Não houve correlação satisfatória entre a variabilidade espacial dos atributos da fertilidade do solo da área experimental e do estágio de desenvolvimento das espécies de plantas daninhas mapeadas. 


\title{
SITE-SPECIFIC CHEMICAL APPLICATION BASED ON THE SPATIAL VARIABILITY OF WEEDS
}

\author{
Author: Fábio Henrique Rojo Baio \\ Adviser: Prof. Titular Luiz Antonio Balastreire
}

\section{SUMMARY}

The weeds present spatial variability in the field. This spatial variability allows the mapping and the control of these plants on a site-specific basis. The purposes of this work were to develop and to evaluate a method for determination of the time of response of an equipment for site-specific chemical application, to evaluate the herbicide efficiency and economy by using this system, to compare two methods for weed mapping and to analyze the spatial variability correlation between the weed species and the soil fertility attributes. The evaluated method for time of response determination was shown to be practical and fast. The time of response of the evaluated system was $28 \mathrm{~s}$. It was possible to identify and to map six weed species in the field by two different methods. The method of weed mapping by systematic sampling was shown very low, less practical and it demanded a larger time to get the final weed map. The method of weed mapping by weed patch contour was faster than the previous one to get the data in the field and to get the final weed map. However, this method was shown subjective. A prescription map with four herbicide application rates was created according to the spatial variability of weeds. The as-applied map was consistent with the prescription map. The weeds were controlled efficiently. The system evaluated for site-specific 
chemical application allowed 31,6\% of herbicide economy, when compared with the traditional method using a single rate for the whole field. There was not an adequate correlation between the spatial variability of soil fertility attributes and the stage of development of weed species. 


\section{INTRODUÇÃO}

Para a maioria dos produtos agrícolas, o preço varia em função da oferta e da procura, não sendo possível ao agricultor aumentar o preço do seu produto quando for de seu desejo. Desta forma, a única maneira do agricultor elevar o lucro obtido com o seu produto é diminuindo os seus custos de produção. Muitos esforços têm sido realizados no sentido de minimizar estes custos de produção.

O controle das plantas daninhas corresponde a uma grande fatia no custo de produção de uma cultura. Atualmente, cerca de 53\% dos defensivos utilizados na agricultura são herbicidas, mas há uma pressão pública pela diminuição do uso indiscriminado destes produtos que vêm causando muitas contaminações no ambiente, colocando em evidência a discussão sobre a utilização dos mesmos na agricultura.

Certamente as plantas daninhas são tão antigas quanto a agricultura e, mesmo nos primórdios da agricultura, os agricultores perceberam que a sua presença provoca diminuição na produtividade da cultura.

Procedimentos para diminuir a utilização de herbicidas contribuem para a redução da contaminação do ambiente e promover o aumento da margem de lucro do agricultor. Estes procedimentos podem estar baseados na variabilidade espacial dos fatores de produção.

Sabe-se que as plantas daninhas não se desenvolvem uniformemente em toda a área. Esta variabilidade espacial é passível de ser mapeada, permitindo a tomada de decisão sobre o melhor manejo para cada local do campo. A possibilidade da detecção e mapeamento das manchas de ocorrência de plantas daninhas cria a oportunidade do controle somente nas áreas de ocorrência das mesmas. Esta linha de raciocínio segue os conceitos da Agricultura de Precisão pela identificação da variabilidade espacial e temporal de algum fator de produção, possibilitando a adoção de práticas de manejo que consideram esta variabilidade. 
A força motriz da agricultura de precisão é a variabilidade espacial e a chave para o seu sucesso é a informação, sendo necessária a utilização de tecnologias avançadas para a obtenção e interpretação da maior quantidade possível de informações sobre o processo produtivo.

Com o advento destes novos conceitos da agricultura estão sendo desenvolvidos novos equipamentos capazes de realizar a aplicação do defensivo agrícola somente no local desejado e na dosagem necessária para aquele local. A adoção desta tecnologia permite uma economia de defensivos, com a conseqüente redução na agressão do ambiente, dos animais e do homem, além de promover uma utilização mais racional dos recursos agrícolas. No entanto, os equipamentos que realizam a aplicação localizada de defensivos possuem algumas características que devem ser consideradas e estudadas para uma adequada pulverização agrícola. Uma das características de maior importância num equipamento desses é o seu tempo de resposta.

A habilidade de descrever e mapear a distribuição espacial das plantas daninhas é o primeiro passo para o estudo de sua variabilidade espacial e para a determinação da melhor metodologia para a aplicação localizada de defensivos, mas estas técnicas ainda estão em desenvolvimento. Os mapeamentos podem dar suporte para a elaboração de mapas de prescrição para que os equipamentos realizem a aplicação localizada de defensivos. Esses mapas também podem ser correlacionados com mapas de outros atributos, visando o estudo das possíveis interações entre estes fatores de produção.

Este estudo teve por objetivos: (a) desenvolver e avaliar uma metodologia para determinação do tempo de resposta de um equipamento para aplicação localizada de defensivos montado num pulverizador automotriz; (b) avaliar a eficiência e a economia de herbicida alcançadas pela utilização de um sistema para aplicação localizada de defensivos, baseado na variabilidade espacial das plantas daninhas; (c) comparar duas metodologias para o mapeamento de plantas daninhas visando a obtenção de mapas de prescrição; (d) estudar a correlação da variabilidade espacial entre espécies de plantas daninhas e atributos da fertilidade do solo como fonte de informação na geração de mapas de prescrição para a realização da aplicação localizada de defensivos. 


\section{REVISÃO DE LITERATURA}

\subsection{Controle químico das plantas daninhas}

De acordo com diversos autores (Anderson, 1983; Mortimer, 1990 e Blanco \& Blanco, 1991) as plantas daninhas são aquelas que crescem em locais onde não são desejadas. Para estes autores, o objetivo principal do controle das plantas daninhas é a maximização do lucro ou a minimização do risco de dano à cultura.

Para Rizzardi \& Pires (1996) as plantas estão sujeitas a uma série de fatores ambientais que, direta ou indiretamente, influenciam em seu crescimento, desenvolvimento e produtividade. A presença de plantas "indesejadas" que emergem espontaneamente nos ecossistemas agrícolas, pode condicionar a uma série de fatores bióticos atenuantes sobre as plantas cultivadas, interferindo não só em sua produtividade, mas também na operacionalização do sistema de produção. Por isto estas plantas recebem o nome de plantas daninhas, causando prejuízos devido a competição, a alelopatia, a interferência na colheita e a hospedagem de pragas, de doenças e de nematóides.

Num campo agrícola sem a adoção de práticas para o controle de plantas daninhas as perdas na produtividade da cultura podem variar de 10 a 100\%, dependendo da habilidade competitiva da cultura (Kropff \& Laar, 1993).

A bibliografia relata as vantagens da utilização de herbicidas para o controle de plantas daninhas em relação aos outros métodos de controle, tais como: o controle mais rápido e eficiente; não causa injúrias nas plantas cultivadas; diminui a incidência de pragas e doenças; facilita os tratos culturais e a colheita; permite o controle mais rápido das plantas daninhas perenes (Blanco \& Blanco, 1991).

Segundo as estatísticas do consumo de herbicidas, o Brasil consumiu no ano 2000 cerca de 68 milhões de quilogramas de ingrediente ativo de herbicidas, 
correspondendo a um mercado de US\$ 1.176 milhões. Dentre todas as classes dos defensivos agrícolas, os herbicidas ocupam 54\% do mercado (Ahlgrimn, 2000).

Thornton et al. (1990) explanam que somente há a necessidade da realização do controle das plantas daninhas nos locais onde sua população superou o nível de dano econômico da cultura. O conceito do nível de dano econômico pode ser sintetizado como a população de uma espécie de planta daninha, por unidade de área, que venha a promover uma diminuição significativa na produtividade da cultura maior do que o custo para o seu controle.

Os herbicidas podem ser classificados em relação ao estágio de desenvolvimento da planta daninha, da cultura ou de ambas. Os herbicidas préemergentes (PRE) são aqueles aplicados antes da germinação das plantas daninhas. Os herbicidas pré-plantio incorporados (PPI) são aqueles aplicados e incorporados antes do plantio da cultura e germinação das plantas daninhas. Os herbicidas pós-emergentes (POS) são aqueles aplicados após a emergência das plantas daninhas (Lorenzi, 1994).

Para a escolha do herbicida a ser utilizado no controle de plantas daninhas, algumas considerações devem ser feitas, como: a cultura que está sendo cultivada, as espécies de plantas daninhas presentes na área, o estágio de desenvolvimento, o sistema de cultivo que está sendo adotado, os perigos ambientais, a seletividade e o custo. Já para a seleção da dosagem deste herbicida visando o eficiente controle das plantas daninhas, outros fatores devem ser considerados, tais como: o nível de infestação, o teor de matéria orgânica presente no solo e sua textura, o tipo de argila, a temperatura, a umidade do solo, o pH do solo e outros (Anderson, 1983 e Gelmini et al., 1994).

\subsection{Pulverização agrícola}

Segundo Andreason (1983), o objetivo principal da pulverização de defensivos agrícolas é aplicar a dosagem correta do defensivo no alvo desejado.

A aplicação de algum defensivo agrícola pode ser crucial para atingir a produtividade almejada da cultura. Em muitos casos, devido à pulverização mal realizada, podem haver perdas significativas na produtividade, ocasionadas por uma reincidência da doença, pela reincidência de alguma praga ou mesmo por não ter havido o controle eficiente das plantas daninhas na área (Gadanha Júnior, 2000). Portanto, o 
monitoramento da qualidade da aplicação de defensivos agrícolas é muito importante para o eficiente controle de fatores danosos às culturas e, conseqüentemente, para a obtenção da produtividade esperada.

De acordo com Gadanha Júnior (2000), o sucesso na aplicação do defensivo depende de vários parâmetros, não somente na escolha do defensivo adequado, mas também na escolha e regulagem do equipamento de pulverização, bem como na habilidade do operador em manuseá-lo. Segundo o autor, muitos pulverizadores aplicam o defensivo na dosagem correta somente quando operam na velocidade de calibração, porém, esta velocidade não permanece constante durante a aplicação.

\subsection{Variabilidade espacial das plantas daninhas}

As plantas daninhas possuem mobilidade limitada, ao contrário da maioria das pragas e doenças. Porém, também podem comprometer toda a produção de uma cultura se não forem tomadas medidas de controle a partir do nível de dano econômico.

De acordo com Häusler \& Nordmeyer (1995) e Nordmeyer et al. (1997), há uma tendência de várias espécies de plantas daninhas em formarem padrões espaciais de agregação definidos. Esta distribuição, embora irregular, implica no fato de certas regiões do campo estarem livres de plantas daninhas ou abaixo do nível de dano econômico. Este fato pode ser devido a determinadas características biológicas das espécies, como o sistema radicular perene ou devido a influência de fatores locais, como a fertilidade do solo.

Para Häusler \& Nordmeyer (1995), as mudanças na topografia, no tipo de solo, na fertilidade, na umidade, na drenagem, na compactação, dentre outros, são os principais determinantes da variabilidade espacial das plantas daninhas num campo agrícola, influenciando a densidade e a composição de suas populações.

Esta variabilidade espacial pode ser mapeada por técnicas que ainda estão

em desenvolvimento na agricultura de precisão. "A agricultura de precisão é um conjunto de técnicas que permitem o gerenciamento localizado de culturas" (Balastreire, 2000, p.5).

Tisdale et al. (1993) relatam que há mais de cinqüenta fatores que afetam o crescimento da planta. Os autores dividiram estes fatores entre fatores climáticos, fatores 
edáficos e fatores inerentes a planta. De acordo com os autores, muitos destes fatores podem ser manejados, como a fertilidade do solo, já outros possuem difícil manejo, como a intensidade luminosa.

Johnson et al. (1997) citam que a variabilidade espacial das manchas de plantas daninhas pode ser relativamente estável durante o período de dez anos. Os autores relatam que esta estabilidade é devido a persistência do banco de sementes das plantas daninhas no solo e às condições locais, que tendem a ser estáveis ao longo dos anos e propiciam o desenvolvimento das plantas daninhas já adaptadas. Falhas no controle de plantas daninhas, entretanto, contribuem para a formação de novas manchas.

Gerhards et al. (1997) e Colbach et al. (2000) estudaram a variabilidade espacial e temporal de algumas espécies de plantas daninhas em campos agrícolas por quatro e por cinco anos, respectivamente. Os autores observaram uma persistência das manchas de plantas daninhas em permanecerem estáveis nos mesmos locais ao longo dos anos de estudos.

\subsection{Mapeamento da variabilidade espacial das plantas daninhas}

A habilidade de descrever e mapear a distribuição espacial das plantas daninhas é o primeiro passo para o estudo da sua variabilidade espacial e da determinação da melhor metodologia para o controle localizado.

De acordo com Balastreire \& Baio (2001a), a metodologia para o mapeamento de plantas daninhas deve: proporcionar um mapeamento rápido devido ao dinamismo das suas populações, quando este mapa serve de base para o mapa de prescrição utilizado no mesmo ciclo da cultura; além disso, ela deve ser simples, facilitando a execução do mapeamento; há um período ideal para a sua execução, considerando-se o momento da realização do controle das plantas daninhas; devido ao fator de escala econômica, deve ser uma metodologia que possa ser aplicada em áreas extensas.

As informações requeridas para a geração dos mapas de plantas daninhas, subsidiando a criação dos mapas de prescrição, podem ser oriundas do caminhamento ao redor das manchas pelo campo, de fotografia aérea, de dados de anos anteriores, de técnicas por sensoriamento remoto, do registro das plantas daninhas durante a colheita 
ou tratos culturais, de atributos do solo e da experiência do agricultor (Nordmeyer et al., 1997).

Além da localização das áreas de ocorrência, algumas informações adicionais sobre as plantas daninhas são úteis para a posterior elaboração do mapa de prescrição. Estas informações devem ser coletadas durante o mapeamento. Deve-se verificar o estágio de desenvolvimento das plantas daninhas, as espécies presentes e a densidade de ocorrência (Clay et al., 1999).

\subsubsection{Mapeamento de plantas daninhas por amostragens sistemáticas}

Muitos pesquisadores, que estudaram a aplicação localizada de defensivos, realizaram o mapeamento de plantas daninhas por amostragens sistemáticas na área. Este método consiste em coletar informações sobre as espécies presentes numa área amostral georreferenciada, localizada em pontos previamente estabelecidos por uma grade. Após esta etapa, o mapa de plantas daninhas pode ser obtido por processos de interpolações das informações coletadas nas áreas amostrais. Cardina et al. (1997) e Clay et al. (1997) citam a possibilidade da realização do mapeamento das plantas daninhas em pontos amostrais aleatoriamente georreferenciados pelo campo.

Muitos trabalhos sobre o mapeamento da variabilidade espacial das plantas daninhas tem sido publicados. Em grande parte destes trabalhos, o mapeamento das plantas daninhas, quando realizado por amostragens sistemáticas, é efetuado em pontos estabelecidos por uma grade regular. Porém, ainda não houve um consenso entre os pesquisadores para a definição da melhor grade amostral, assim como para a definição da área amostral mais representativa, como é observado no Quadro 1. A área amostral é definida como a menor área na qual a composição das espécies da comunidade em estudo naquela região do campo está adequadamente representada. 


\begin{tabular}{|ccccl|}
\hline $\begin{array}{c}\text { Grade } \\
\text { amostral } \\
(\mathrm{m})\end{array}$ & $\begin{array}{c}\text { Área amostral } \\
\left(\mathrm{m}^{2}\right)\end{array}$ & $\begin{array}{c}\mathrm{N}^{\text {o }} \\
\text { amostras.ha }^{-1}\end{array}$ & $\begin{array}{c}\text { Área } \\
\text { amostrada } \\
\left(\mathrm{m}^{2} \cdot \mathrm{ha}^{-1}\right)\end{array}$ & \multicolumn{1}{c|}{ Autores } \\
\hline $2 \times 2$ & 0,07 & 2500,00 & 187,50 & Zanin et al. (1998) \\
$3 \times 1,5$ & 0,25 & 2222,22 & 555,56 & Cardina el al. (1997) \\
$3 \times 3$ & 0,25 & 1111,11 & 277,78 & Eberlein et al. (1998) \\
$6,1 \times 6,1$ & 0,10 & 268,74 & 26,87 & Colbach et al. (2000) \\
$7 \times 7$ & 0,38 & 204,08 & 77,55 & Gerhards et al. (1997) \\
$7 \times 7$ & 0,20 & 204,08 & 40,82 & Lindquist et al. (1998) \\
$8 \times 8$ & 0,27 & 156,25 & 42,19 & Wile \& Schweizer (1999) \\
$10 \times 10$ & 0,25 & 100,00 & 25,00 & Heisel et al. (1996a) \\
$12 \times 12$ & 0,25 & 69,44 & 17,36 & Christensen et al. (1999) \\
$12 \times 12$ & 0,25 & 69,44 & 17,36 & Heisel et al. (1997) \\
$15 \times 15$ & 0,01 & 44,44 & 0,44 & Williams el al. (1999) \\
$20 \times 20$ & 0,25 & 25,00 & 6,25 & Heisel et al. (1996b) \\
$20 \times 20$ & 0,25 & 100,00 & 25,00 & Walter et al. (1997) \\
$30 \times 30$ & 0,10 & 11,11 & 1,11 & Nordmeyer et al. (1997) \\
$30 \times 30$ & 0,10 & 11,11 & 1,11 & Clay et al. (1999) \\
$50 \times 50$ & 0,40 & 4,00 & 1,60 & Nordmeyer \& Dunker (1999) \\
\hline
\end{tabular}

Quadro 1 - Exemplos de grades e de áreas amostrais utilizadas por alguns autores para a realização de mapeamentos de plantas daninhas por amostragens sistemáticas.

De acordo com Johnson et al. (1997), o detalhamento do mapeamento da variabilidade espacial de uma determinada planta daninha depende da densidade da grade de coleta de amostras em campo. Gerhards et al. (1997) obervaram que quando o mapeamento de plantas daninhas é realizado numa grade regular, manchas pequenas de plantas daninhas podem não ser mapeadas, pois elas podem ocorrer ao redor do ponto georreferenciado, não sendo detectadas dentro da área amostral. Heisel et al. (1996a) relatam que quanto maior a distância entre os pontos amostrais, menor a acurácia dos mapas gerados.

Clay et al. (1999) concluíram que o mapeamento de plantas daninhas por amostragens sistemáticas possui limitações práticas em campo, pois necessita de elevado tempo e mão-de-obra, tornando-se impraticável em grandes áreas.

Heisel et al. (1996a), Walter et al. (1997) e Heisel et al. (1999) concluíram que a co-krigagem pode ser utilizada para diminuir o esforço amostral em mapeamentos de plantas daninhas por amostragens sistemáticas. Para tanto, os autores sugerem a 
utilização de atributos da fertilidade do solo e mapas de plantas daninhas dos anos anteriores.

\subsubsection{Mapeamento de plantas daninhas com auxilio de cartas cartográficas}

Segundo Kiser \& Williams (2000), o mapeamento de plantas daninhas num campo agrícola pode ser realizado com o auxílio de uma carta cartográfica (escala 1:5000 ou 1:10000) ou mesmo com o auxílio de alguma planta topográfica da área em questão. Por este método, não há a necessidade da utilização do sistema de posicionamento. A metodologia consiste em marcar, na carta ou planta topográfica, a localização das manchas e as espécies de plantas daninhas existentes no campo.

De acordo com Kiser \& Williams (2000), esta não é uma metodologia acurada para a localização das manchas de ocorrência, servindo somente para a aquisição de dados para a formação de uma base histórica. Lass \& Callihan (1993) mostraram que a realização do mapeamento de plantas daninhas pela estimativa da localização das manchas no campo, sem a utilização do sistema de posicionamento, proporcionou um mapa com as manchas de plantas daninhas em locais e com áreas errôneos, quando comparado com o mapa obtido com o auxílio do GPS.

Esta carta ou planta topográfica em formato analógico pode ser transformado para o formato digital por meio da digitalização. Uma vez em formato digital, o mapa pode ser processado pelo programa de SIG (Sistemas de Informações Geográficas).

\subsubsection{Mapeamento de plantas daninhas por técnicas de sensoriamento remoto}

O mapeamento de plantas daninhas pode ser realizado com o auxílio de técnicas de sensoriamento remoto. Fotografias e videografias aéreas são utilizadas para a delimitação das áreas de ocorrência das plantas daninhas em campos cultivados ou em pousio. As câmeras, digitais ou analógicas, podem ser instaladas nas mais diversas plataformas, como: aviões, balões ou aeromodelos rádio-controlados (Antuniassi, 1998). As imagens também podem ser obtidas pelo uso de câmeras digitais instaladas em veículos que circulam sobre o campo a ser mapeado (Christensen et al., 1994). Estas imagens são então processadas para a elaboração dos mapas de plantas daninhas. 
De acordo com Ehlert \& Jürschik (1997), os equipamentos mais comuns são capazes de operar na faixa do espectro visível e infravermelho, sendo possível a diferenciação entre o solo e as plantas. Antuniassi (1998) e Zwiggelaar (1998) sugerem a aquisição das imagens por sensores que trabalham nas bandas do visível e do infravermelho. Lamb \& Weedon (1998) realizaram um mapeamento de plantas daninhas pela aquisição de imagens nas bandas do infravermelho, vermelho, verde e azul, por câmeras com resolução espacial de $1 \mathrm{~m}^{2}$ instalada num avião. Num método semelhante Broulik et al. (1999), utilizaram uma câmera digital com resolução de $1 \mathrm{~m}^{2}$ operando na banda do infravermelho.

Segundo Christensen et al. (1994) e Lamb \& Weedon (1998), a acurácia no mapeamento depende principalmente da resolução espacial da câmera. Nordmeyer et al. (1997) verificaram que o mapeamento de plantas daninhas por fotografia aérea somente se mostrou eficaz quando a densidade populacional das plantas daninhas foi superior a 150 plantas. $m^{-2}$. Também observaram que não foi possível a diferenciação das espécies de plantas daninhas presentes nas imagens devido a sua baixa resolução espacial.

Stafford \& Benlloch (1997), Vrindts \& Baerdemaeker (1997) e Pérez et al. (2000) encontraram dificuldade na diferenciação entre as plantas daninhas e a cultura, devido a semelhança entre suas assinaturas espectrais. Zwinggelaar (1998) comenta que a diferenciação entre a plantas e o solo é bastante fácil, pois suas assinaturas espectrais são distintas. Para a seleção das bandas exatas que devem ser utilizadas, Zwiggelaar (1998) comenta que esta escolha depende das espécies a serem mapeadas. O autor ainda relata que as informações geométricas dos alvos de interesse podem ser necessárias para a distinção entre eles.

A assinatura espectral é a curva característica que cada alvo possui (objeto, planta, água, solo, etc.) que relaciona a sua refletância para cada região do espectro eletromagnético.

A difusão da utilização de imagens provenientes de sensores instalados em

plataformas orbitais esbarra na baixa resolução espacial destes sensores para o mapeamento de plantas daninhas, na baixa repetitibilidade das cenas de interesse e no alto custo de aquisição destas imagens (Morgan \& Ess, 1997).

No entanto, o processo de aquisição de imagens para o mapeamento de plantas daninhas por sensoriamento remoto é relativamente rápido e é possível a 
realização do mapeamento em grandes extensões de área (Brown et al., 1991 e Lamb \& Weedon, 1998). Um período maior de tempo é exigido para a análise e classificação destas imagens em programas de SIG.

\subsubsection{Mapeamento de plantas daninhas pelo método linear}

O mapeamento de plantas daninhas pelo método linear é aquele realizado pelo caminhamento em linhas paralelas na área, marcando-se os locais onde sua presença é detectada. Esta operação pode ser realizada numa operação específica ou em conjunto com outra operação agrícola, como: a colheita, a adubação de cobertura ou o plantio.

Jensen \& Hall (1999) mencionam que o mapeamento de plantas daninhas por esta metodologia pode ser realizado rapidamente com o auxílio de um veículo ATV ("All Terrain Vehicle") instrumentado com o sistema de posicionamento e um programa computacional.

Walter et al. (1997) relatam que o método linear de mapeamento de plantas daninhas é mais eficiente onde há somente uma espécie presente. Segundo os autores, este método não é apropriado para o mapeamento de várias espécies num campo cultivado devido a dificuldade causada pela barreira visual provocada pela cultura.

Rew et al. (1996), utilizando a metodologia linear do mapeamento de plantas daninhas, atribuíram conceitos (nula, baixa ou alta infestação) para as densidades de ocorrência das espécies durante o mapeamento. A gravação dos dados foi realizada diretamente no sistema DGPS ("Differential Global Positioning System").

Colliver et al. (1996) comentam que o operador da colhedora automotriz deve ficar atento para o acionamento do sistema de localização das plantas daninhas quando é realizada a operação de mapeamento em conjunto com a colheita da cultura. Segundo os autores, os mapas gerados por esta metodologia podem conter longas manchas de plantas daninhas que foram mapeadas em locais onde não havia sua presença, ocasionadas pelo erro do operador. Os autores concluíram também que estes mapas de plantas daninhas tendem a superestimar a área onde houve a presença delas, proporcionando o aumento do custo do controle localizado devido ao maior dispêndio de herbicida. 


\subsubsection{Mapeamento de plantas daninhas pelo método do contorno das manchas de ocorrência}

Este método consiste em percorrer os perímetros das áreas de ocorrência de plantas daninhas, identificando as espécies presentes e o estágio de desenvolvimento (Antuniassi, 1998 e Balastreire \& Baio, 2001a). Este procedimento pode ser realizado com o auxílio de algum veículo para facilitar o deslocamento pelo campo em áreas extensas.

Balastreire \& Baio (2001a) realizaram dois mapeamentos das plantas daninhas pelo método do contorno das manchas de ocorrência, no mesmo campo agrícola, em dois períodos distintos. Os autores verificaram que o tempo necessário para a execução do mapeamento está diretamente relacionado com a complexidade da distribuição espacial das plantas daninhas. Segundo os autores, o planejamento do melhor momento para a realização do mapeamento deve ser realizado considerando-se o dinamismo populacional das plantas daninhas.

Colliver et al. (1996) avaliaram três metodologias para o mapeamento de plantas daninhas. Os autores efetuaram os mapeamentos das plantas daninhas por amostragens sistemáticas, pelo contorno das manchas de ocorrência e pelo método linear. Tiveram como resultados infestações de 68,6; 66,5 e 90\% da área total, respectivamente. Concluíram que a metodologia mais eficiente é a de contorno das manchas de plantas daninhas, por ser mais acurada que a metodologia de mapeamento durante a colheita e mais rápida que a metodologia de mapeamento por amostragens sistemáticas.

\subsection{Mapeamento da fertilidade do solo}

O mapeamento da fertilidade do solo é bastante utilizado na agricultura de precisão, fornecendo subsídios para a aplicação localizada de fertilizantes e corretivos. Porém, mapas de atributos da fertilidade do solo também são gerados para ajudar no entendimento da variabilidade espacial da produtividade da cultura ou mesmo da variabilidade espacial das plantas daninhas. 
Morgan \& Ess (1997) explanam que o mapeamento da fertilidade do solo pode ser realizado por duas metodologias distintas, onde as amostras podem ser coletadas numa grade regular ou em zonas de manejo (zonas nas quais os solos possuem características semelhantes). A metodologia por amostragens em grade ainda pode ser subdividida em duas vertentes, onde as amostras podem ser coletadas em pontos georreferenciados nesta grade ou coletadas aleatoriamente dentro de cada célula. De acordo com Sánchez (1981), as amostras de solo devem ser coletadas em regiões do campo que possuem as mesmas características: topográficas, coloração, textura, manejo, etc.

McBratne y \& Pringle (1997) discorrem que um atributo do solo pode ser mapeado de maneira contínua no campo pelo emprego de sensores que detectam a variabilidade espacial do atributo, como os sensores de condutividade elétrica para medir a salinidade do solo.

Muitos trabalhos estão sendo desenvolvidos para o estudo da melhor metodologia para a amostragem de solo, determinação do número de amostras por hectare ou do melhor número de sub-amostras (Mohamed et al., 1996; Pocknee et al., 1996; Clay et al. 1999a e Yang et al., 1999)

O principal fator determinante do número de amostras por hectare num mapeamento da fertilidade do solo é o nível de detalhamento. Se, para uma dada finalidade, for necessário o maior detalhamento da variabilidade espacial do determinado atributo, a distância amostral deve ser reduzida. No entanto, se for necessário somente o estudo da variabilidade espacial do atributo numa escala menor (mapas com escalas pequenas cobrem grandes áreas) a distância amostral pode ser aumentada.

Para comprovar esta linha de raciocínio, White \& Zasoski (1999) elaboraram um mapa de fertilidade do solo ilustrando a variabilidade espacial do nutriente zinco para todo os EUA, utilizando técnicas geoestatísticas e interpolação por krigagem. A distância amostral foi em média de $80 \mathrm{~km}$, mesmo assim, os autores puderam elaborar o mapa desejado. Buscando estudar a variabilidade espacial de atributos do solo através de técnicas geoestatísticas, Paz-González et al. (2000) realizaram um mapeamento da fertilidade do solo numa grade amostral quadrática de $2 \mathrm{~m}$ de lado. Warrick et al. (1986) mencionam que as técnicas geoestatísticas podem ser utilizadas para caracterizar e 
mapear a variabilidade espacial de atributos do solo em escalas, variando de centímetros a quilômetros.

Mapas de atributos da fertilidade do solo podem ser utilizados para a elaboração de mapas de prescrição de herbicidas baseados na variabilidade espacial dos atributos mapeados (Qiu et al., 1998). Sabe-se que a determinação das dosagens de alguns herbicidas depende das características dos solos onde eles serão aplicados. Propriedades dos solos como a textura, a CTC (capacidade de troca de cátions), o pH (potencial hidrogeniônico) e a matéria orgânica interferem no nível de adsorção de alguns herbicidas aplicados, como os herbicidas PRE e PPI, necessitando de dosagens diferenciadas de acordo com o nível do atributo para o controle eficiente das plantas daninhas (Rodrigues \& Almeida, 1998). Alguns autores têm realizado trabalhos relacionados com a aplicação localizada de herbicidas a razões variáveis de acordo com a variabilidade espacial de atributos do solo (Gaadi \& Ayers, 1999; Khakural et al., 1999 e Qiu et al., 1998).

\subsection{Correlação entre mapas de plantas daninhas e atributos do solo}

O grau da variabilidade espacial e temporal das plantas daninhas é resultado de diversas interações entre estas plantas e o meio (Johnson et al., 1997).

Häusler \& Nordmeyer (1995) observaram uma estreita correlação entre o aumento do nível da fertilidade do solo e o aumento da ocorrência das espécies de plantas daninhas estudadas.

Quando é observada alguma correlação significativa entre a variabilidade espacial de atributos da fertilidade do solo e a variabilidade espacial de plantas daninhas os mapas da fertilidade do solo podem ser utilizados para auxiliar na elaboração de mapas de plantas daninhas por técnicas geoestatísticas. Diversos autores têm demonstrado correlações estatisticamente significativas entre estes atributos (Andreasen \& Streibig, 1991; Walter et al., 1997; Khakural et al., 1999 e Nordmeyer \& Dunker, 1999).

Qiu et al (1998) desenvolveram uma estratégia para o controle de plantas daninhas baseada nas propriedades dos solos, competição de plantas daninhas e potencial produtivo do campo, utilizando a aplicação localizada de defensivos a razões 
variáveis. O potencial econômico desta técnica pode ser atingido pela redução ou eliminação do herbicida nos locais com baixo teor de matéria orgânica ou nos locais onde o controle de plantas daninhas não seja um problema histórico.

\subsection{Sistema de Posicionamento Global - GPS}

Há algumas formas para a localização do equipamento no campo. Rockwell \& Ayers (1994) citam quatro possibilidades para a localização do veículo dentro de um campo agrícola. A primeira delas é a localização pela utilização de sensores que medem distâncias num caminhamento em linhas paralelas, como as linhas de plantio. A segunda possibilidade citada pelos autores é a localização pelo uso de sensores de distância e bússolas eletrônicas. A terceira possibilidade é a localização pela triangulação de ondas de rádio emitidas por estações situadas em pontos de coordenadas conhecidas. A quarta possibilidade, e a mais conhecida, é a localização do veículo pelo uso do Sistema de Posicionamento Global.

O GPS ("Global Positioning System") é um sistema projetado para fornecer o posicionamento instantâneo, bem como a velocidade do ponto sobre ou próximo a superfície da Terra (Blitzkow, 1995). Este sistema foi desenvolvido pelo Departamento de Defesa dos EUA, originalmente criado com fins militares estratégicos. Atualmente empregado nas mais diversas áreas civis.

De acordo com Blitzkow (1995), o sistema conta com 24 satélites, sendo três de reserva. Estes satélites, denominados NAVISTAR ("Navigation System with Time and Ranging"), estão distribuídos em 6 órbitas distintas, numa altitude aproximada de 20 mil quilômetros e possuem um período de revolução de 12 horas. Com esta configuração, em qualquer ponto da superfície da Terra há no mínimo 4 satélites acima da linha do horizonte durante todo o dia.

Blitzkow (1995) também explana que, de uma maneira simplificada, o posicionamento por meio do GPS é baseado na triangulação entre os satélites, que possuem coordenadas conhecidas em suas órbitas, e o receptor GPS. Para a realização desta triangulação, o receptor GPS determina a distância receptor-satélite por equações que consideram o período de tempo entre a emissão do sinal de rádio, a partir de sua saída do satélite, e a recepção deste sinal pelo receptor. 
O GPS calcula as coordenadas do ponto de acordo com uma superfície de referência, chamada de elipsóide. O sistema GPS utiliza o datum WGS 84 ("World Geodetic System" 1984). O datum nada mais é do que um conjunto de vértices de triangulação referenciais nos quais o elipsóide é ajustado. O elipsóide de referência para o datum WGS 84 é o GRS 80 (“Global Reference System” 1980) (Blitzkow, 1995 e Lange, 1996).

Baio et al. (1998) citam as principais fontes de erro para o posicionamento do sistema GPS, como a disposição geométrica dos satélites, o efeito do multicaminhamento, o erro do relógio do receptor GPS, a interferência da ionosfera e o erro orbital do satélite.

Uma das alternativas encontradas para o posicionamento acurado com o GPS é o posicionamento relativo, denominado DGPS ("Differential Global Positioning System"), onde um receptor é colocado fixo num ponto com coordenadas previamente estabelecidas (base), enquanto o outro (veículo) é situado no ponto cujas coordenadas são almejadas (Blitzkow, 1995). Esta correção pode ser realizada em tempo real ou numa operação chamada de pós-processamento. Balastreire (1998) faz uma explanação sobre as possibilidades para o posicionamento relativo em tempo real, como a utilização de sinais de rádio emitidos por bases próprias, particulares ou públicas, ou emitidas por satélites geoestacionários. Balastreire \& Baio (2001b) mostram que o posicionamento relativo pode ser substituído por algum sistema que utiliza um algoritmo para a melhoria da acurácia no posicionamento, alcançando coordenadas tão acuradas quanto às obtidas pela utilização do DGPS.

Como explana Stafford (1996), o rápido desenvolvimento da agricultura de precisão nos últimos anos se deve ao acesso do público civil ao sinal GPS. Para o autor, a acurácia do DGPS em operações para aplicação localizada de defensivos deve estar entre 0,5 e $1 \mathrm{~m}$. Qiu et al. (1998) sugerem que o DGPS deve possuir acurácia ao redor de $2 \mathrm{~m}$ para a realização do mapeamento de plantas daninhas.

\subsection{Geoestatística}

"Quando uma determinada propriedade varia de um local para outro, com algum grau de organização ou continuidade, expresso através da dependência espacial, a 
estatística convencional deve ser abandonada e dar lugar a uma estatística relativamente nova: a Geoestatística" (Vieira, 2000, p.93).

A base da geoestatística vem da Teoria das Variáveis Regionalizadas de Matheron. Segundo esta teoria, a diferença nos valores de uma dada variável tomados em dois pontos do campo depende da distância entre eles (Vieira, 1995). Assim, a diferença entre os valores do atributo tomados em dois pontos mais próximos no espaço deve ser menor do que a diferença entre os valores tomados em dois pontos mais distantes. Portanto, cada valor carrega consigo uma forte interferência dos valores de sua vizinhança, ilustrando a continuidade espacial (Isaaks \& Srivastava, 1989).

A geoestatística aplicada à agricultura de precisão tem por objetivos identificar na aparente desordem entre as amostras uma medida da correlação espacial, realizar estimativas de valores de locais não amostrados a partir de alguns valores conhecidos na população (krigagem) e identificar inter-relações de propriedades no espaço (análises de correlação entre atributos), além de permitir estudar padrões de amostragem adequados (Vieira, 2000).

Uma etapa fundamental que antecede a análise geoestatística é a realização de uma criteriosa análise exploratória dos dados. Deve-se verificar a normalidade dos dados, verificar se há candidatos a dados discrepantes ("outliers") ou se há a necessidade da transformação dos dados para a sua normalização (Isaaks \& Srivastava, 1989 e Gonçalves et al., 1999).

Quando se utiliza a ferramenta geoestatística para a análise dos dados, algumas hipóteses de trabalho são assumidas, principalmente a hipótese intrínseca. Por esta hipótese, a probabilidade de variação dos valores tomados entre pontos com a mesma distância de separação é igual, ou seja, a relação da dependência espacial é a mesma em qualquer posição de h (h é o vetor que separa dois pontos amostrais). É assumida a estacionaridade dentro do alcance da continuidade espacial. A estacionaridade de primeira ordem é a esperança do valor de um ponto no espaço ser igual à média, admitindo-se que a média amostral é igual à média populacional. A estacionaridade de segunda ordem assume que há uma variação da média, mas a variância é constante dentro dos limites da continuidade espacial (Vieira, 1995 e Isaaks \& Srivastava, 1989). 


\subsubsection{O semivariograma}

Para avaliar se há dependência espacial entre as amostras utiliza-se o semivariograma. Segundo Vieira (2000), o semivariograma é uma ferramenta utilizada para medir e descrever a dependência espacial e expressa o grau de semelhança entre o ponto e os seus vizinhos. O semivariograma nada mais é do que um gráfico que representa a estimativa das semivariâncias dos dados (ã $(\mathrm{h})$ ) em relação ao vetor correspondente que os separa (h). As observações realizadas em distâncias menores são mais similares do que aquelas tomadas à distâncias maiores.

A estimativa das semivariâncias pode ser alcançada pela expressão (Vieira, 1995):

$$
\gamma(h)=\frac{1}{2 N(h)} \sum_{i=1}^{N(h)}\left[z\left(x_{i}\right)-z\left(x_{i}+h\right)\right]^{2}
$$

sendo:

ã(h) é a semivariância;

$\mathrm{z}\left(\mathrm{x}_{\mathrm{i}}\right)$ e $\mathrm{z}\left(\mathrm{x}_{\mathrm{i}}+\mathrm{h}\right)$ são os pares de valores medidos separados por um vetor $\mathrm{h}$;

$\mathrm{N}(\mathrm{h})$ é o número de pares de valores $\left[\mathrm{z}\left(\mathrm{x}_{\mathrm{i}}\right)-\mathrm{z}\left(\mathrm{x}_{\mathrm{i}}+\mathrm{h}\right)\right]$ separados pelo vetor $\mathrm{h}$;

z é a variável em estudo.

Ao semivariograma experimental é ajustada a curva que proporcione a máxima correlação possível com os pontos plotados. O modelo ajustado é chamado de modelo teórico do semivariograma. Na região onde se observa a continuidade espacial a geoestatística é aplicada com eficiência (Figura 1). 


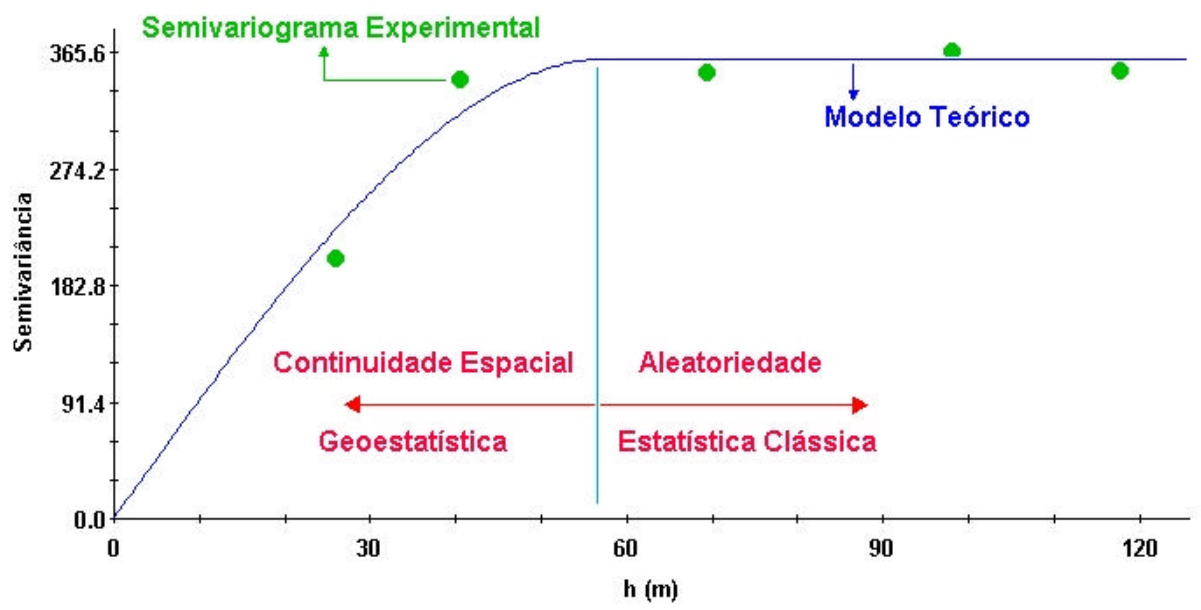

Figura 1 - Semivariograma experimental e modelo teórico.

Isaaks \& Srivastava (1989) e Vieira (1995) relatam sobre os componentes principais do semivariograma, ilustrado na Figura 2. De acordo com os autores, a semivariância decresce na medida em que a distância entre os pontos amostrais (h) decresce. Assim, se as semivariâncias são menores, há uma maior semelhança entre os dados amostrados. A semivariância cresce em função de $\mathrm{h}$ até o ponto onde não se observa mais a continuidade espacial. Este ponto no eixo h é chamado de alcance do semivariograma (a) e no eixo $\tilde{a}(\mathrm{~h})$ é chamado de patamar $(\mathrm{C}+\mathrm{Co})$. Na medida em que $\mathrm{h}$ tende para zero, a semivariância (ã(h)) tende para um valor positivo chamado efeito pepita (Co). O efeito pepita engloba a variação em escala menor que a amostrada e/ou os erros ocorridos nas medições. O componente estrutural (C) é a porção da variação que é explicada pela continuidade espacial. 


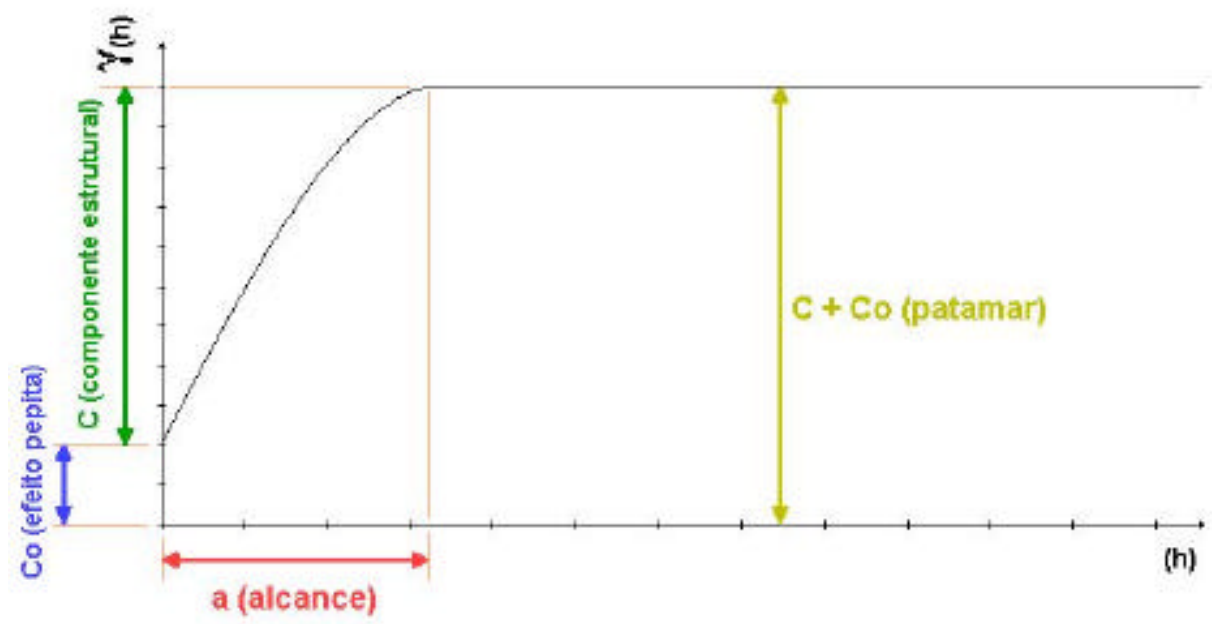

Figura 2 - O semivariograma típico e seus componentes.

$\mathrm{Na}$ Figura 3 são apresentados os principais modelos teóricos de semivariograma. Os modelos mais utilizados são o exponencial, o gaussiano e o esférico (Vieira, 2000).
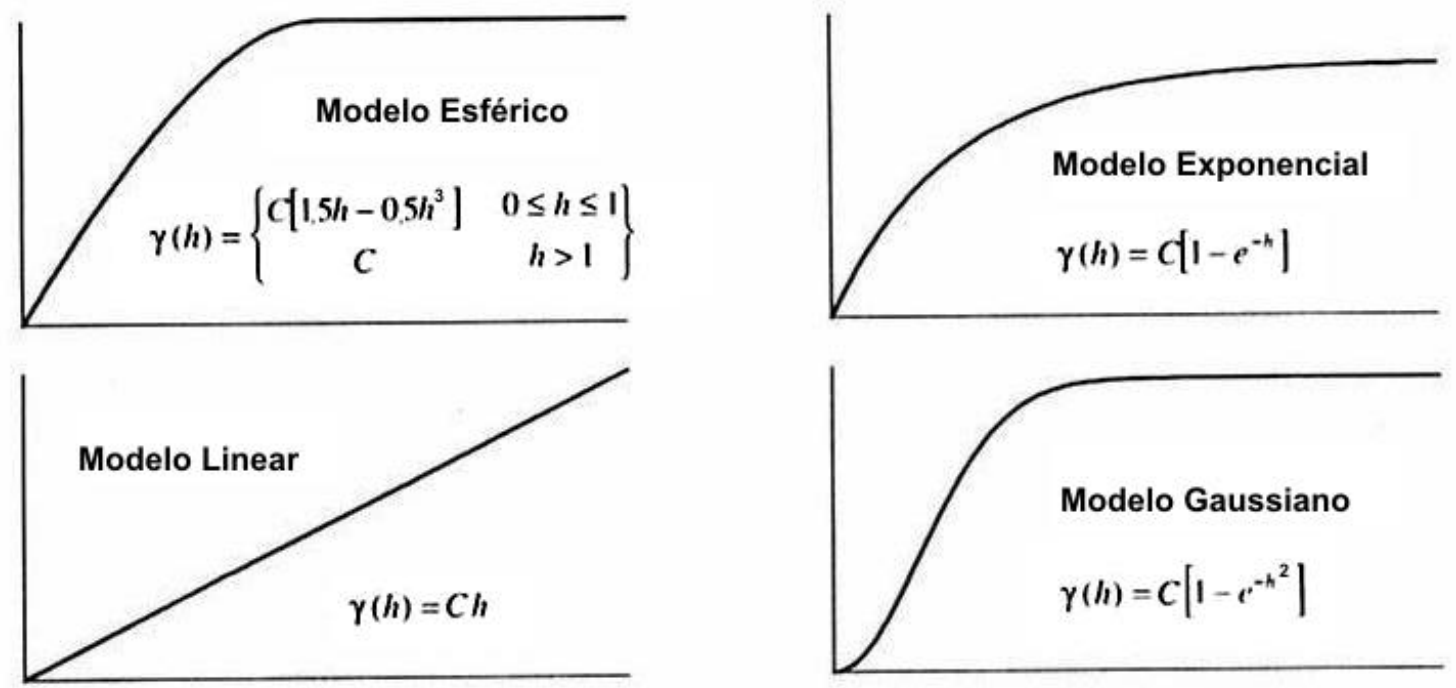

Sendo:

C é o componente estrututal; h é o vetor de separação.

Obs: Adiciona-se o efeito pepita (Co) ao valor da semivariância calculada.

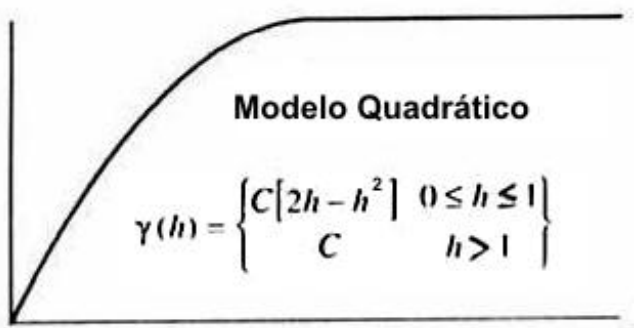

Fonte: Modificado de Golden Software (1995).

Figura 3 - Principais modelos teóricos de semivariogramas. 


\subsubsection{Validação cruzada}

A etapa de ajuste do modelo ao semivariograma experimental é de grande importância, pois pode influenciar os resultados posteriores. O modelo ajustado deve aproximar-se ao máximo da descrição do fenômeno no campo. Gonçalves et al. (1999) explanam que a verificação do melhor ajuste do modelo teórico ao semivariograma experimental pode ser realizada pela validação cruzada.

Há duas metodologias básicas para a realização da validação cruzada (Gonçalves et al., 1999 e Vieira, 1995). Pela primeira metodologia, pode-se ir ao campo com o mapa gerado pela interpolação e fazer uma reamostragem com a finalidade de comparar os valores amostrados com os valores indicados no mapa. Esta metodologia é pouco prática, pois depende da reamostragem para validar o semivariograma criado anteriormente. A metodologia mais utilizada para a realização da validação cruzada do semivariograma é a análise comparativa do valor estimado com o valor real do ponto amostral. Esta metodologia baseia-se na retirada de um valor amostral do conjunto de dados amostrais, sendo então realizada a interpolação por krigagem daquele ponto (utilizando o modelo do semivariograma ajustado para estimar o valor desta amostra). Após a realização desta etapa em cada ponto amostral são comparados os valores reais com os estimados pela krigagem. O semivariograma melhor ajustado é aquele que possui o maior coeficiente de correlação entre os valores reais e estimados.

\subsubsection{Interpolação por krigagem}

O processo de interpolação nada mais é do que, a partir de uma amostra, realizar inferências sobre a população, ou seja, realizar inferências para os pontos não amostrados a partir dos dados coletados nos pontos amostrais (Vieira, 1995).

Existem muitos métodos de interpolação, como: método poligonal, triangulação, médias locais e inverso do quadrado das distâncias. Porém, a forma com que os dados variam de um local para outro no campo não segue nenhuma equação linear ou polinômio.

A krigagem é considerada o melhor método de interpolação linear não tendencioso e com variância mínima, pois considera os parâmetros do semivariograma. 
Nenhum outro método de interpolação é baseado na variância mínima entre as amostras (Isaaks \& Srivastava, 1989).

Na realização da interpolação por krigagem são atribuídos pesos aos valores dos pontos amostrais. Estes pesos variam em função da distância que separa o ponto a ser estimado e o ponto de valor conhecido. Os pesos são atribuídos considerando-se o modelo do semivariograma. O valor do ponto desconhecido é então calculado pela solução de um sistema de matrizes (Isaaks \& Srivastava, 1989).

Gotway et al. (1996) compararam os métodos de interpolação por krigagem e pelo inverso do quadrado da distância para a obtenção dos mapas dos atributos da fertilidade do solo. Os autores verificaram que as duas metodologias utilizadas produziram resultados semelhantes, porém, a metodologia pelo inverso do quadrado da distância proporcionou mapas com manchas circulares concêntricas, típicas deste método de interpolação. Os autores verificaram também que a krigagem não se mostrou um método de interpolação eficiente nos casos onde havia um elevado efeito pepita. Já Kravchenko \& Bullock (1999), num estudo similar, concluíram que o melhor método de interpolação para dados de fertilidade do solo é a krigagem.

\subsection{Sistemas de Informações Geográficas - SIG}

Os Sistemas de Informações Geográficas (SIG) são um conjunto de ferramentas computacionais que permitem o armazenamento, o processamento, a análise e a sintetização de dados georreferenciados, bem como a produção de informação derivada de sua aplicação (Moreira, 2001 e Câmara \& Medeiros, 1998).

De acordo com Moreira (2001), os SIG são compostos por três componentes básicos: o equipamento computacional ("hardware"); o conjunto de módulos aplicativos ("software") e o contexto organizacional apropriado. Na medida em que os dados são coletados, cada parâmetro pode ser tratado como uma camada de informação ("layer"). O sistema oferece a possibilidade de executar operações lógicas entre os diferentes planos de informações, sendo capazes de integrar muitos conjuntos de dados num único sistema. De acordo com o autor, o sucesso ou o fracasso na obtenção de informações acuradas sobre a realidade do campo depende, principalmente, da qualidade dos dados introduzidos no SIG. 
De acordo com Moreira (2001), qualquer SIG apresenta duas características principais: inserem e integram num único banco de dados, informações espaciais provenientes de diversas fontes e oferecem um mecanismo para combinar estas informações, através de algoritmos de manipulação e análise, bem como de consulta, de recuperação, de visualização e de impressão do conteúdo do banco de dados georreferenciados. O autor enfatiza que os principais produtos gerados nos SIG são mapas, mas também são geradas importantes informações através de gráficos e relatórios.

$\mathrm{Na}$ aplicação localizada de defensivos os SIG possuem papel fundamental na geração dos mapas de plantas daninhas, geração dos mapas de prescrição, assim como no estudo das correlações entre os mapas gerados.

\subsection{Aplicação localizada de defensivos}

Johnson et al. (1997), Stafford \& Benlloch (1997) e Antuniassi (1998) descrevem três alternativas para a realização da aplicação localizada de herbicidas por tecnologias distintas. Pela primeira tecnologia, a aplicação localizada de defensivos pode ser realizada pela detecção instantânea das plantas daninhas através do uso de sensores ou câmeras digitais. As informações provenientes destes equipamentos são processadas em tempo real, possibilitando a localização das plantas daninhas no campo e promovendo a aplicação do herbicida somente nos locais onde as mesmas são detectadas. Porém, estes sensores são muito sensíveis a variações de luminosidade, variações das características do solo e das plantas, necessitando de calibrações constantes ao longo da aplicação (Johnson et al., 1997 e Biller et al., 1997). A segunda tecnologia para a aplicação localizada de defensivos é baseada no conceito do mapeamento das plantas daninhas. O mapeamento de plantas daninhas é realizado numa operação anterior a pulverização. Então, são elaborados os mapas de prescrição, que servem de base para a aplicação localizada de defensivos. Estes mapas possuem dosagens ou herbicidas diferentes recomendadas para cada local do campo. No entanto, a aplicação localizada de defensivos baseada neste conceito necessita de algum sistema de posicionamento. Johnson et al. (1997) ainda descrevem uma terceira alternativa para a realização da aplicação localizada de defensivos baseada na variabilidade espacial de 
alguns fatores edáficos. Segundo os autores, a variação das dosagens do herbicida (PRE ou PPI) pode ser realizada de acordo com a variabilidade espacial de alguns atributos do solo que foram mapeados previamente e que serviram de base para a elaboração do mapa de prescrição.

Stafford \& Miller (1996) citam algumas vantagens da aplicação localizada de defensivos baseada no conceito do mapeamento de plantas daninhas, quando comparada à aplicação localizada de defensivos baseada no conceito do controle em tempo real:

- tomada de decisão para seleção do herbicida mais apropriado para o controle das espécies presentes, incluindo a possibilidade da variação de dosagens;

- tecnicamente existem vários métodos para o mapeamento das plantas daninhas, podendo ser escolhida a melhor metodologia para um determinado ciclo da cultura ou condições de manejo;

- há uma maior flexibilidade para a escolha do melhor momento para a realização do mapeamento, considerando-se a biologia da planta daninha e o ciclo da cultura;

- há a possibilidade do mapeamento durante os tratos culturais rotineiros;

- há a possibilidade da pulverização de herbicidas PRE ou PPI;

- existe a possibilidade da mudança da estratégia para o controle das plantas daninhas após a análise do mapeamento realizado;

- é possível a determinação prévia da quantidade exata de defensivo a ser utilizada.

No entanto, Stafford \& Miller (1996) relatam algumas desvantagens da metodologia:

- a metodologia requer algum sistema de posicionamento;

- o mapeamento deve ser realizado e processado por programas específicos, como um SIG;

- programas específicos para a interface entre o sistema de posicionamento e o controlador eletrônico são necessários; 
- erros na aplicação podem ocorrer devido a problemas durante o mapeamento ou durante a geração do mapa de prescrição;

- as metodologias para o mapeamento de plantas daninhas são passíveis de erros;

- há um dinamismo na população das plantas daninhas, podendo mudar suas características num curto espaço de tempo.

\subsubsection{Aplicação localizada baseada no conceito do controle de plantas daninhas em tempo real}

De acordo com Morgan \& Ess (1997), o princípio do funcionamento deste sistema envolve a diferenciação entre as assinaturas espectrais do solo e das plantas daninhas. Os sensores utilizados analisam uma ou mais faixas do espectro eletromagnético. Como relatam estes autores, há equipamentos que dependem da luz solar para o seu funcionamento e outros que possuem a sua própria fonte de luz, podendo operar em diversas condições de luminosidade. A cada instante, o sensor óptico capta a refletância do alvo, que é então analisada pelo microprocessador. Há a liberação da calda sobre o alvo se o mesmo possuir assinatura espectral semelhante à da planta, sendo ela uma planta daninha ou cultivada (Figura 4).

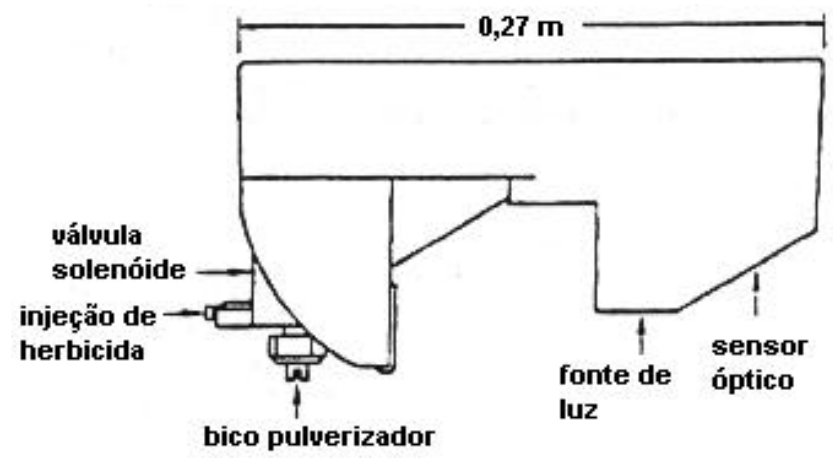

Fonte: Adaptado de Morgan \& Es s (1997).

Figura 4 - Esquema de um sensor para a aplicação localizada de herbicidas em tempo real.

Mas a distinção entre espécies de plantas daninhas diferentes por estes sensores é difícil devido a similaridade entre suas assinaturas espectrais, como relatam 
Vrindts \& Baerdemaeker (1997). Para estes autores, dependendo da espécie de planta daninha que se deseja identificar é necessária a utilização de sensores com elevadas resoluções espacial e espectral. Um sistema de detecção de plantas daninhas em tempo real requer a utilização de sensores seguros e de um pulverizador calibrado, que proporcione uma resposta rápida ao comando de aplicação. Segundo os autores, a velocidade de aplicação também depende da resolução espacial do equipamento. A sincronização entre a detecção da planta daninha e a aplicação deve ser assegurada para diferentes velocidades de aplicação.

Sadjadi (1996) e Scarr et al. (1997) realizaram a identificação de plantas daninhas através de técnicas de sensoriamento remoto utilizando uma câmera de infravermelho próximo. Analisando a resposta espectral e a textura da imagem foi possível identificar a ocorrência e distinguir as espécies de plantas daninhas.

De acordo com Biller et al. (1997), a aplicação localizada baseada no conceito do controle de plantas daninhas em tempo real pode proporcionar uma economia de herbicida na ordem de 30 a 70\% e com eficiência de $100 \%$ no controle, concordando com Engqvist et al. (1997), que alcançaram uma redução de $90 \%$ no consumo de herbicida.

Para Antuniassi \& Gadanha Júnior (2000), uma das principais dificuldades da utilização desta tecnologia é a necessidade da recalibração constante dos sensores, em função da variação das características da superfície de aplicação.

\subsubsection{Aplicação localizada baseada no conceito do mapeamento}

Um dos grandes problemas da tecnologia para a aplicação localizada de defensivos é a determinação da variabilidade espacial das plantas daninhas num curto espaço de tempo e com um mínimo custo para o agricultor.

Por esta tecnologia é necessária a realização de duas etapas distintas: a geração dos mapas bases e a aplicação localizada com algum equipamento apropriado, de acordo com o mapa de prescrição (Antuniassi, 1998).

Nordmeyer et al. (1997), utilizando a tecnologia para a aplicação localizada de defensivos pelo conceito do mapeamento de plantas daninhas, realizaram a aplicação de um herbicida POS em somente $60 \%$ da área. 
De acordo com Nuspl et al. (1996) é possível uma economia de herbicida na ordem de 30 a $80 \%$ quando é utilizada a tecnologia para a aplicação localizada de defensivos em áreas mapeadas, comparada ao consumo de herbicida aplicado em área total. Yao et al. (1999) verificaram uma redução no consumo de herbicida na ordem de $45 \%$ pela utilização desta tecnologia.

\subsection{Injeção direta de defensivos}

A aplicação localizada de defensivos baseada no conceito do mapeamento pode ser realizada por sistemas mais simples que possuem válvulas solenóides, efetuando somente o controle do local de aplicação por um sistema "liga/desliga" (Paice et al., 1996 e Antuniassi \& Gadanha Júnior, 2000). Por este sistema não é possível a variação da dosagem do defensivo. Já os sistemas mais sofisticados permitem variações de dosagens dos defensivos e/ou do volume aplicado. A variação de dosagens do defensivo é geralmente realizada por sistemas de injeção direta. O princípio básico do funcionamento deste sistema está relacionado ao armazenamento do defensivo e do diluente em recipientes separados. A mistura é realizada somente no momento da aplicação, através da injeção do defensivo na tubulação que leva a calda aos bicos do pulverizador.

Qiu et al (1998) e Koo \& Summer (1998) apresentam algumas vantagens do sistema de injeção direta de defensivos, como: a eliminação do desperdício de defensivos; a menor exposição do operador aos defensivos; a possibilidade da seleção automática, e em tempo real, da dosagem de defensivos para cada local do campo; a possibilidade do controle de injeção de herbicidas diferentes numa mesma aplicação. Antuniassi \& Gadanha Júnior (2000) explanam que os sistemas de injeção direta de defensivos proporcionam uma melhor acurácia no controle da dosagem do defensivo para o local de aplicação, já que há o monitoramento contínuo da dosagem aplicada. O sistema, além disso, possibilita a troca de dosagens dos defensivos sem afetar o volume de aplicação.

No entanto, nem todos os sistemas de injeção direta de defensivos possuem uma interface com o sistema de posicionamento, permitindo variações automáticas de dosagens de defensivos de acordo com o mapa de prescrição (Nordmeyer et al., 1996). 


\subsubsection{Componentes principais de um equipamento para injeção direta de defensivos}

Clark \& McGuckin (1996) fazem uma explanação sobre os componentes principais de um equipamento para injeção direta de defensivo. Segundo os autores, o elemento central necessário para efetuar a aplicação localizada é o microprocessador, que gerencia todas as informações provenientes dos sensores. Estas informações são processadas juntamente com aquelas contidas num banco de dados (mapa de prescrição), possibilitando o controle do equipamento de injeção direta. Os componentes principais de um equipamento para aplicação localizada por injeção direta de defensivos podem ser visualizados na Figura 5.

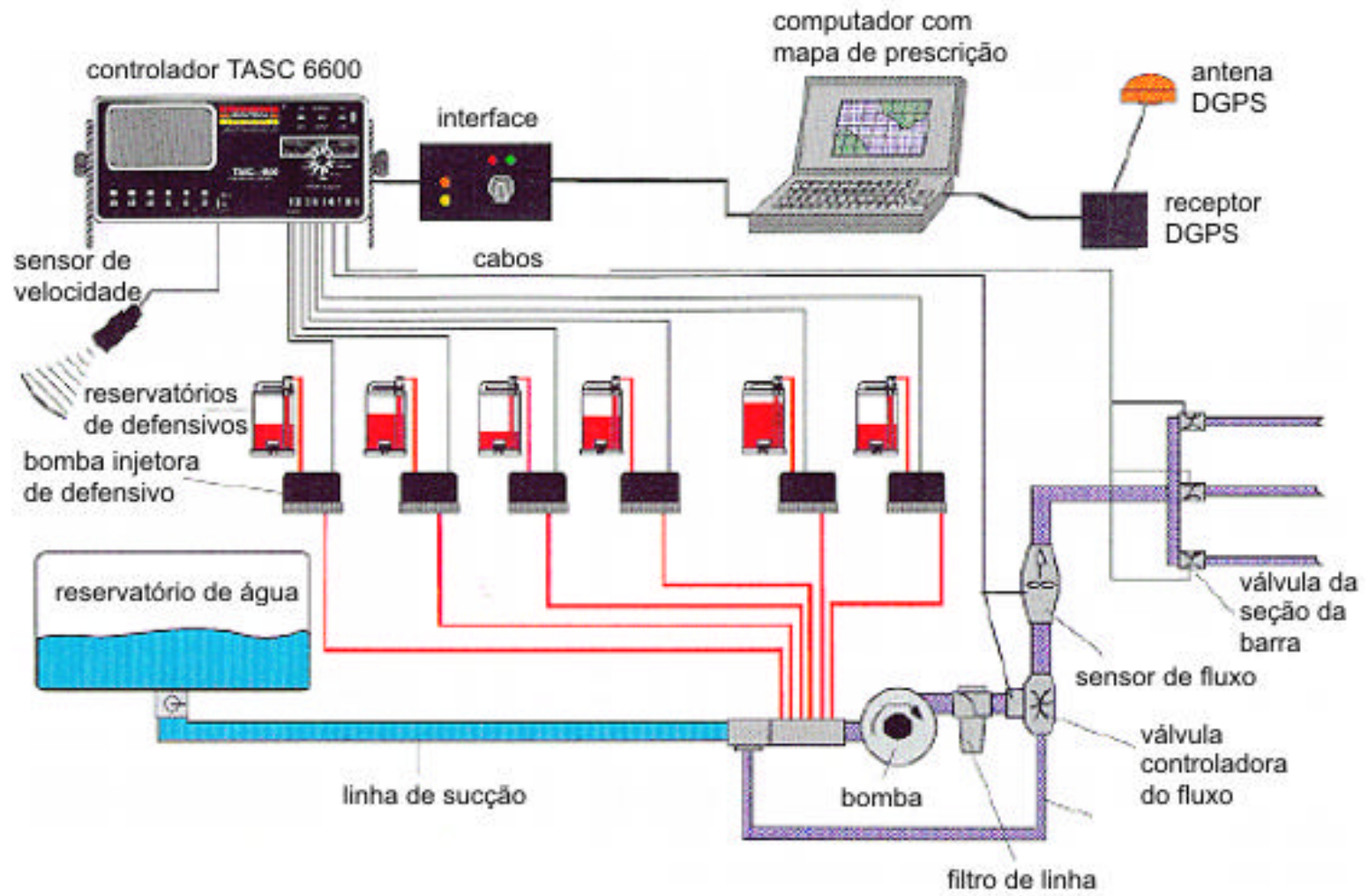

Fonte: Adaptado de MidTech (2001).

Figura 5 - Componentes principais de um equipamento para aplicação localizada por injeção direta de defensivos. 
Morgan \& Ess (1997) descrevem sobre os componentes principais presentes num sistema de injeção direta de defensivos: os sensores; os controladores e os atuadores. Segundo os autores, os sensores são os dispositivos que suprem o controlador com informações provenientes do sistema. O sistema de posicionamento pode ser considerado um sensor, pois ele disponibiliza a informação de posição para o controlador. Outros sensores estão presentes num equipamento de injeção direta de defensivos, como sensores de pressão, sensores de vazão e sensores de velocidade. Os controladores são os dispositivos dotados de microprocessadores que realizam a integração e análise das informações provenientes dos sensores, permitem o cálculo da dosagem correta para o determinado local e realizam o controle dos atuadores. Muitos controladores trabalham em conjunto com computadores portáteis através de alguma interface apropriada. Os atuadores são os dispositivos que respondem aos comandos emitidos pelos controladores, possibilitando a dosagem do produto aplicado.

Os sistemas de injeção direta de defensivos utilizam como atuadores, em sua maioria, bombas injetoras de pistões ou peristálticas (Antuniassi, 1998). Os sistemas dotados de bombas peristálticas são projetados para a injeção do defensivo na tubulação do pulverizador num ponto anterior a bomba principal. Tem por característica elementar a baixa pressão de injeção, impossibilitando a injeção do defensivo na tubulação de saída da bomba principal do pulverizador. Os sistemas de injeção direta de defensivos que possuem bombas injetoras de êmbolo são caracterizados pela maior pressão de injeção, possibilitando a disposição do ponto de injeção após o sistema de bombeamento principal do pulverizador. Em ambos os sistemas, a variação da dosagem do defensivo é efetuada pelo controle da rotação da bomba injetora. Em termos comparativos, o autor comenta que os sistemas de injeção direta de defensivos dotados de bombas de êmbolo possuem menor tempo de resposta, pois o ponto de injeção é localizado mais próximo aos bicos do pulverizador. Mas os sistemas dotados de bombas peristálticas, por apresentarem o ponto de injeção numa localização anterior a bomba principal do pulverizador, possuem a vantagem da melhor homogeneização da calda, tornando desnecessária a adoção de um dispositivo específico. As bombas peristálticas, por trabalharem em regimes de pressões menores, apresentam menor desempenho quando há mudanças nas características físicas das soluções injetadas. 


\subsubsection{Requisitos técnicos dos equipamentos para injeção direta de defensivos}

Giles et al. (1996), Paice et al. (1996), Antuniassi et al. (1997) e Qiu et al. (1998) comentam sobre os requisitos técnicos do equipamento ideal para injeção direta de defensivos, como a acurácia da dose aplicada, a alta resolução espacial do equipamento, permitir a variação de dosagens e permitir a aplicação de diferentes formulações de defensivos.

Antuniassi et al. (1997) ainda comentam que os equipamentos para a aplicação localizada devem fornecer acurácia melhor do que $\pm 5 \%$ na dosagem desejada e operar em faixas de variação de doses em 5:1, concordando com Paice et al. (1996).

Como explanam Qiu et al. (1998), a configuração do sistema de injeção direta de defensivos deve permitir a manutenção da dosagem proporcional à variação da velocidade do pulverizador.

Para Paice et al. (1996), a acurácia da dosagem aplicada por equipamentos que realizam a aplicação localizada de defensivos é provavelmente mais importante que em equipamentos que realizam a pulverização em área total com dosagem única. A Figura 6 ilustra a curva de dose-resposta para uma típica combinação entre o incremento do herbicida aplicado (\%) e o aumento das plantas daninhas controladas (\%). Pode ser observado que quando a pulverização é realizada com a dosagem do herbicida próxima a recomendada para o controle, uma variação da dosagem em $20 \%$ em torno da dosagem ideal $(100 \%)$ tem um pequeno efeito sobre a variação das plantas daninhas controladas. No entanto, quando se trabalha com dosagens reduzidas de herbicida, uma pequena variação da dosagem aplicada promove uma grande variação na porcentagem das plantas daninhas controladas. 


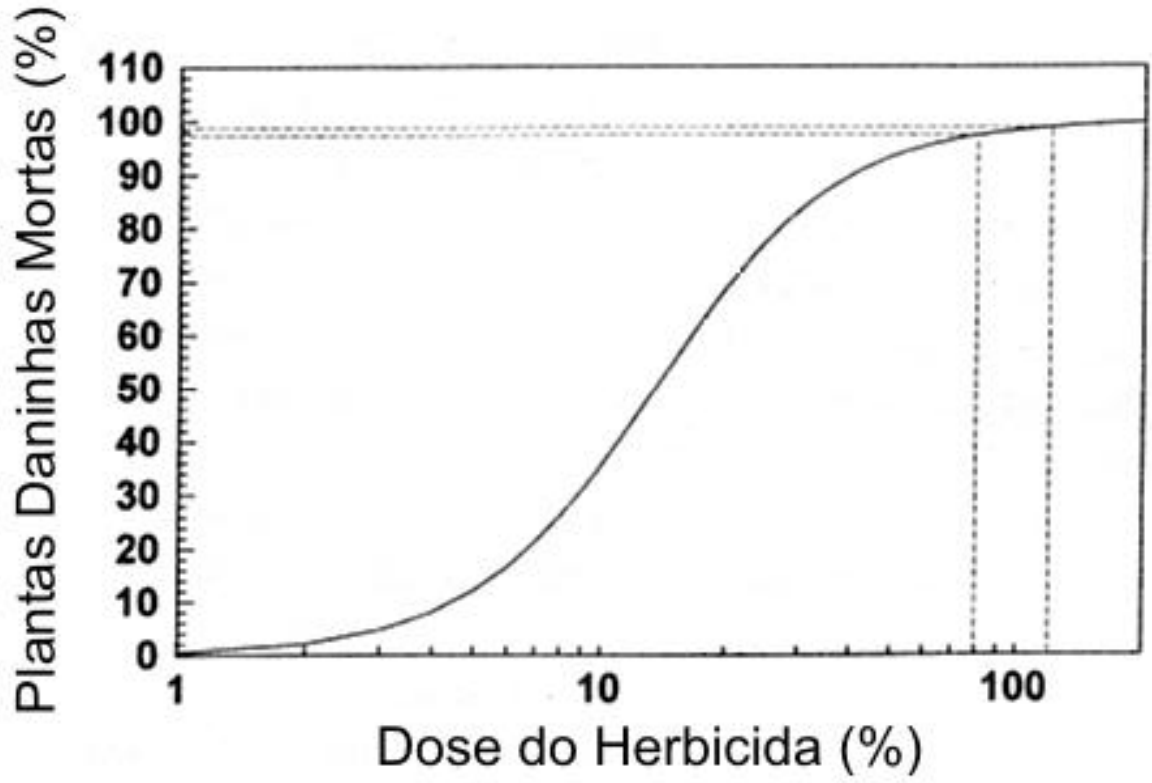

Fonte: Adaptado de Paice et al. (1996).

Figura 6 - Curva de dose-resposta para uma típica combinação entre o incremento do herbicida aplicado (\%) e o aumento das plantas daninhas controladas (\%).

Os equipamentos para aplicação localizada de defensivos devem manter constante a pressão do sistema principal do pulverizador, segundo Gadanha Júnior (2000). Os pulverizadores tradicionais são normalmente limitados numa determinada variação de pressão, podendo sacrificar a qualidade e a uniformidade da operação em baixas pressões e aumentar consideravelmente a deriva operando em altas pressões.

Para Nuspl et al. (1996), um dos mais importantes requisitos de um sistema de injeção direta de defensivos é a realização da adequada homogeneização da calda antes da aplicação. Segundo os autores, a calda não é distribuída, com a mesma concentração, em toda a extensão da barra do pulverizador ao mesmo tempo. No momento da injeção do defensivo no sistema ainda há calda na barra com a dosagem anterior e, para a aplicação da nova dosagem, há a necessidade do esgotamento de toda a calda remanescente. Portanto, a calda preenche gradativamente toda a extensão da barra com a nova dosagem. Para os autores, este efeito é chamado de difusão transversal. Alguns bicos estão mais próximos do ponto de inserção da linha do pulverizador do que outros, estes bicos irão receber a calda com a nova dosagem primeiro. Este fato provoca um efeito em "W" da aplicação do defensivo sobre o campo quando há a mudança em 
sua dosagem. Os autores concluem que a calda do pulverizador deve estar homogeneizada em toda a extensão da barra do pulverizador antes do início da mancha de plantas daninhas.

Qiu et al. (1998) relatam que erros na dosagem do herbicida podem ser derivados de erros humanos, de erros na pressão do pulverizador, de bicos gastos, de erros de calibração do pulverizador e de erros ocasionais, como a flutuação da velocidade do pulverizador.

\subsubsection{Tempo de resposta}

Um dos mais importantes fatores que definem a eficiência de um equipamento para a aplicação localizada de defensivos em realizar a pulverização da dosagem correta sobre o local desejado é o seu tempo de resposta.

O tempo de resposta pode ser definido como o período entre o comando para a troca da razão de aplicação e sua efetiva mudança nos bicos (Antuniassi et al, 1997). Este período de tempo pode variar em função do ponto de injeção de defensivos no sistema, do volume de aplicação, da densidade do defensivo, do comprimento e do diâmetro das tubulações do pulverizador e da configuração do sistema (Antuniassi et al, 1997; Qiu et al., 1998 e Gadanha Júnior, 2000).

$\mathrm{Na}$ Figura 7 é ilustrada uma simulação da distância percorrida pelo pulverizador (D1 + D2) do instante em que houve a ordem para a troca da razão de aplicação do defensivo (T0) até o instante onde é observado o equilíbrio da concentração do defensivo em toda a extensão da barra do pulverizador (T2), período este que caracteriza o tempo de resposta do equipamento. 


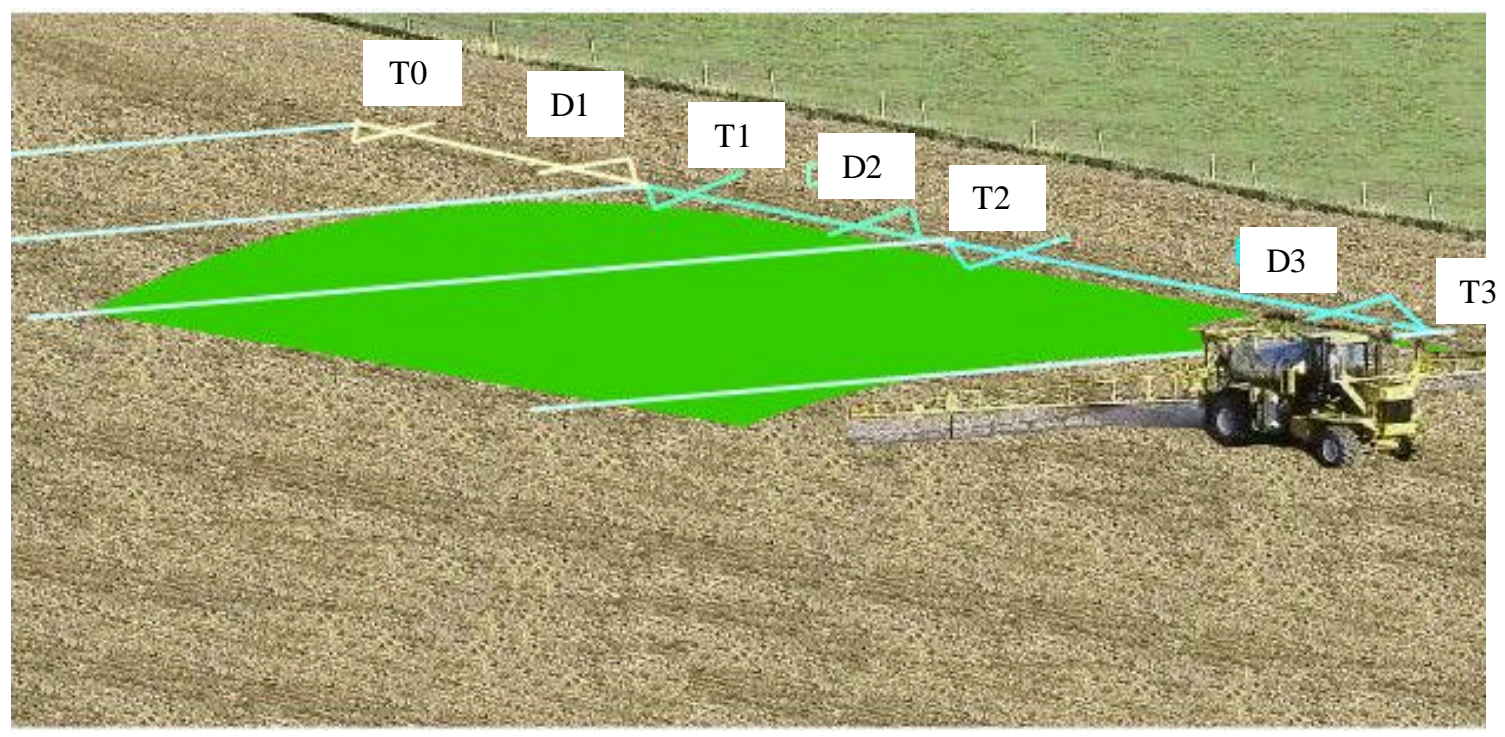

Figura 7 - Simulação da distância percorrida pelo pulverizador (D1 + D2) do instante em que houve a ordem para a troca da razão de aplicação (T0) até o instante onde se observa o equilíbrio da concentração do defensivo em toda a extensão da barra (T2).

Qiu et al. (1998) recomendam que, para diminuir o tempo de resposta do equipamento para injeção direta de defensivos, o ponto de injeção seja colocado o mais próximo da barra do pulverizador. Os autores também mencionam sobre a redução do diâmetro e do comprimento da linha de pressão do pulverizador como outras possibilidades para a diminuição do tempo de resposta, pois reduz o volume da calda da bomba até os bicos, sem aumentar a pressão. Segundo os autores, esta prática pode reduzir o tempo de resposta em até 3 s. Para Paice et al. (1996), esta prática pode reduzir o tempo de reposta em $5 \mathrm{~s}$.

Há algumas metodologias para a determinação do tempo de resposta de um equipamento para aplicação localizada de defensivos, porém, elas geralmente necessitam da instrumentação do pulverizador com sensores e são aplicadas em condições estáticas.

Antuniassi et al. (1997) avaliaram o tempo de resposta de três sistemas de injeção direta de defensivos, com bombas injetoras, de êmbolo e peristáltica. Os autores determinaram o tempo de resposta de cada equipamento por processos colorimétrico e pela mensuração da condutividade elétrica da solução a partir do instante em que houve a ordem para a mudança na dosagem do produto. Verificaram que houve o aumento 
significativo do tempo de resposta quando operaram com um líquido de maior viscosidade.

Sudduth et al. (1995) utilizaram um sistema com laser para a determinação do tempo de resposta do sistema de injeção direta de defensivos Raven SC-700. O sistema com laser desenvolvido determinou o instante em que a concentração da calda mostrou-se constante, a partir do instante onde houve a ordem para a mudança na concentração da calda. Os autores verificaram que o tempo de resposta do sistema variou entre 14 e $21 \mathrm{~s}$, dependendo da configuração utilizada.

Paice et al. (1997) determinaram o tempo de resposta de um sistema para aplicação localizada de defensivos pela aplicação de dosagens crescentes de um herbicida sobre um campo coberto por uma vegetação. As manchas onde houve a ação do herbicida foram mapeadas por radiômetros instalados sobre o veículo.

Nuspl et al. (1996) determinaram o tempo de resposta do sistema de injeção direta de defensivos Mid-Tech TASC 6300 montado sobre um pulverizador. Os autores verificaram que a distância percorrida pelo pulverizador dentro do tempo de resposta foi de $73,1 \mathrm{~m}$.

Qiu et al. (1998) verificaram que o tempo de resposta do sistema de injeção direta de defensivos avaliado variou entre 15,9 e 52,6 s, dependendo da configuração do sistema e do diâmetro das tubulações.

No entanto, o efeito do tempo de resposta pode ser reduzido pela utilização de um sistema computacional ou algoritmo que determine a direção e a velocidade de deslocamento do pulverizador, possibilitando a utilização destes sistemas de injeção direta para a aplicação localizada de defensivos. Com este artifício, o pulverizador é capaz de antecipar a mudança na dosagem que foi planejada para o ponto onde o mesmo estará localizado após o período equivalente ao tempo de resposta do equipamento. Sudduth et al (1995), Nuspl et al. (1996), Paice et al. (1996) e Qiu et al. (1998) chamam este artifício de tempo de adiantamento ("look ahead").

De acordo com Rockwell \& Ayers (1994), o tempo de resposta do equipamento também pode ser expresso pela distância de resposta. Segundo os autores, a distância de reposta proporciona um resultado mais perceptível do que o tempo de resposta em sistemas dinâmicos. 


\section{MATERIAL E MÉTODOS}

\subsection{Caracterização das áreas experimentais}

O ensaio foi conduzido em duas áreas vizinhas na Fazenda Lagoa Velha, localizada na cidade de Campos Novos Paulista, no Estado de São Paulo, cujas coordenadas geográficas aproximadas são: latitude $22^{\circ} 41^{\prime} 40^{\prime \prime}$ S e longitude $49^{\circ} 58^{\prime}$ 58 ' W.

O solo é classificado como Latossolo Vermelho Amarelo Eutrófico, com A moderado e textura média.

Segundo a classificação de Köppen (1948), o clima predominante na região é caracterizado como Cwa em transição para Cfa, especificado como subtropical com verão chuvoso e inverno seco. A temperatura média anual é de $22,3^{\circ} \mathrm{C}$, com variações médias entre $17,7^{\circ} \mathrm{C}$ em julho e $25,2^{\circ} \mathrm{C}$ em fevereiro. A precipitação média anual é de $1468 \mathrm{~mm}$.

Ambas as áreas possuem relevo plano, com declividade inferior a 2\% e estão dispostas uma ao lado da outra, como ilustra a Figura 8. 


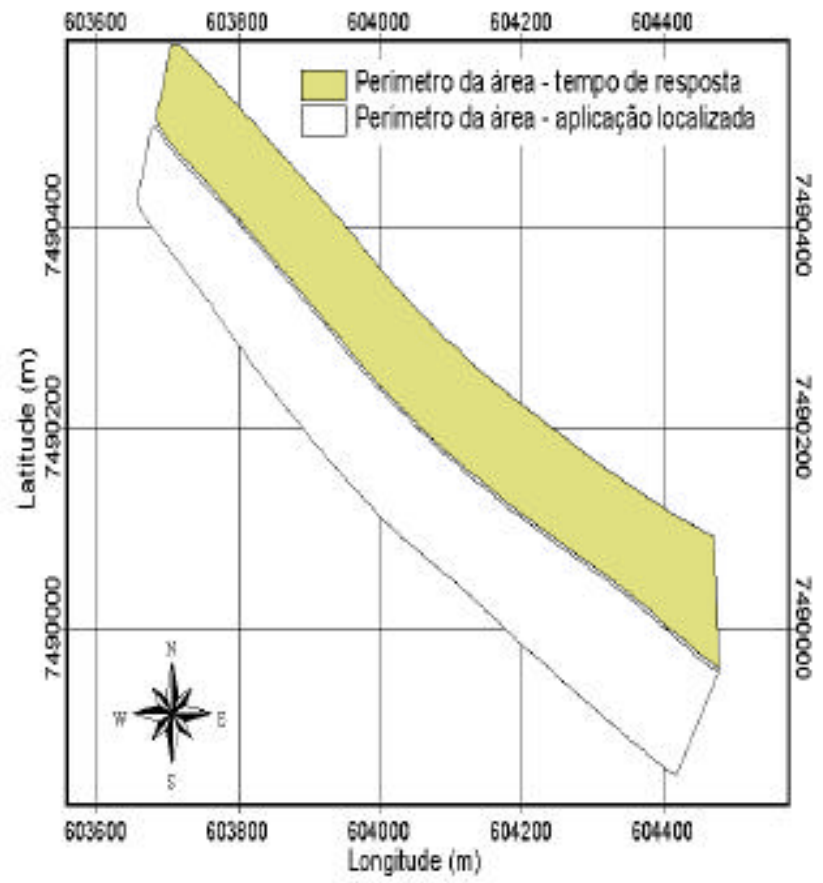

Figura 8 - Disposição das áreas experimentais.

As duas áreas estavam sendo cultivadas, até o período da realização dos ensaios, com a rotação das culturas milho (Zea mays L.) e soja (Glycine max L.) no sistema de plantio direto desde o ano de 1995.

A área experimental onde foi realizado o ensaio para a determinação do tempo de resposta do equipamento para aplicação localizada de defensivos, caracterizada na Figura 8 como "Perímetro da área - tempo de resposta", estava sendo cultivado com milheto (Pennisetum americanum) num estágio de desenvolvimento de 810 folhas, com o objetivo da produção de massa vegetal para a cobertura do solo no sistema de plantio direto (Figura 9). Este campo experimental possui área de 8,8 ha. 


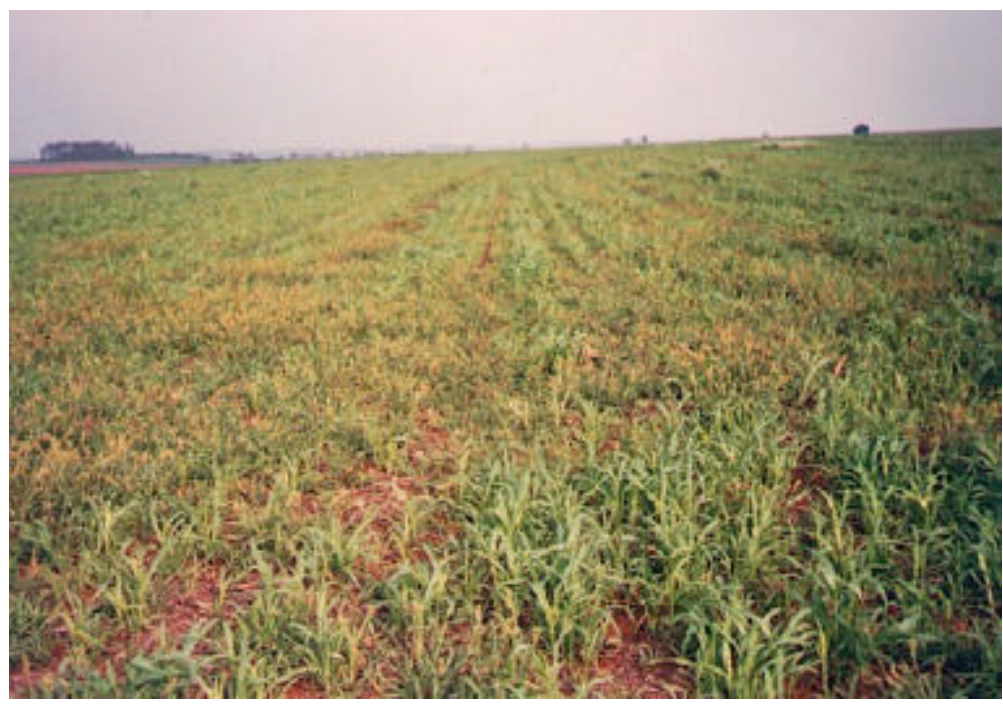

Figura 9 - Ilustração da área experimental onde foi realizado o ensaio para determinação do tempo de resposta do equipamento para aplicação localizada de defensivos.

A área experimental onde foram realizados os mapeamentos de plantas daninhas, o mapeamento de fertilidade e a aplicação localizada de defensivos (Figura 10) possui 9,8 ha e havia restos culturais de milho, os quais foram produzidos no ciclo da cultura anterior.

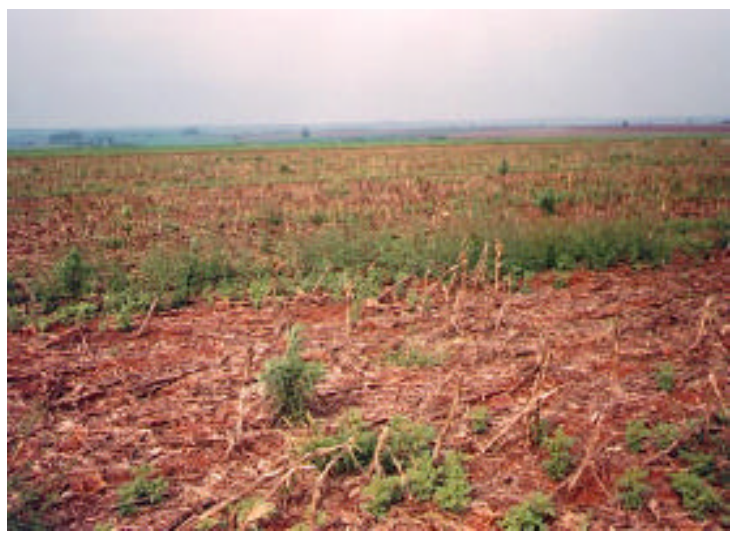

(a)

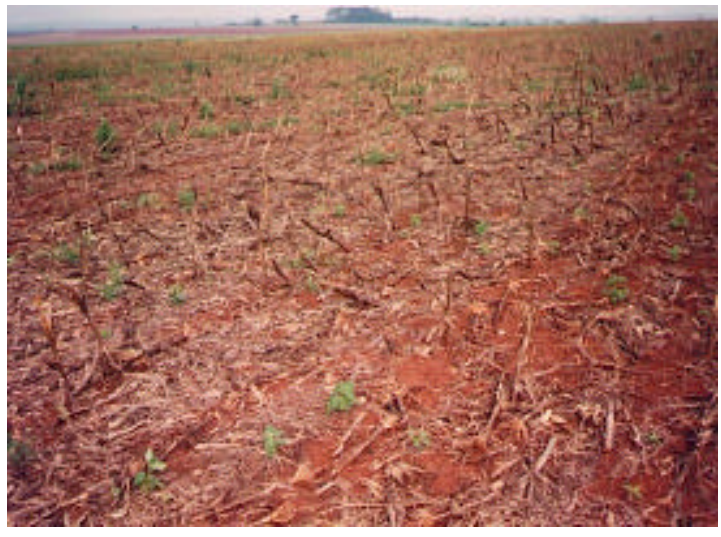

(b)

Figura 10 - Ilustrações da área experimental onde foram realizados os mapeamentos de plantas daninhas, o mapeamento de fertilidade e a aplicação localizada de defensivos: (a) região onde havia uma maior infestação de plantas daninhas e (b) região onde havia uma menor infestação de plantas daninhas. 


\subsection{Sistema de Posicionamento Global - GPS}

O sistema de posicionamento utilizado foi o DGPS Trimble, modelo AG 132, que possui correção diferencial fornecida via satélite pela Empresa Racal e que foi alimentado por uma bateria portátil de 12 volts. Este receptor DGPS utilizou o código C/A ("Coarse/Acquisition") para o posicionamento.

Este DGPS foi utilizado em todas as tarefas do ensaio onde houve a necessidade do sistema de posicionamento. Em ambas as áreas experimentais não havia obstruções físicas para o recebimento dos sinais dos satélites (GPS e DGPS).

O DGPS forneceu a informação de posicionamento para o programa computacional Farm Site Mate, possibilitando o monitoramento das coordenadas na tela de um computador portátil Fujitsu.

\subsection{Programas computacionais}

Em todos os mapeamentos realizados em campo e para o gerenciamento do sistema de injeção direta de defensivos durante a aplicação localizada de defensivos foi utilizado o programa Farm Site Mate (FarmWorks Software) versão 6.8.03. Este programa também gerou o mapa da aplicação (“as-applied”) durante a aplicação localizada de defensivos. Este programa também foi utilizado para a geração dos mapas dos perímetros das áreas experimentais, para a geração das grades amostrais, para a geração dos pontos amostrais e para a navegação em campo até o ponto amostral.

Para a sobreposição, manipulação e interpolação dos mapas obtidos e para o auxílio nos cálculos do tempo de resposta do sistema para aplicação localizada de defensivos foi utilizado o programa de SIG SSToolbox (SST Development Group) versão 3.2.1.

A tabulação dos dados foi realizada pela planilha eletrônica Excel (Microsoft Inc.) versão 2000 .

O programa estatístico SAS, versão 6.11 (SAS Institute Inc.), foi utilizado para todos os cálculos estatísticos e para a realização dos cálculos das correlações existentes entre os mapas de plantas daninhas e os mapas dos atributos da fertilidade do solo. 
A análise geoestatística foi realizada com o auxílio do programa GS+ (Gamma Design Software) versão 3.11.20.

\subsection{Pulverizador automotriz}

Foi utilizado o protótipo de um pulverizador automotriz (Figura 11) para a realização dos ensaios da determinação do tempo de resposta e para a aplicação localizada de defensivos.

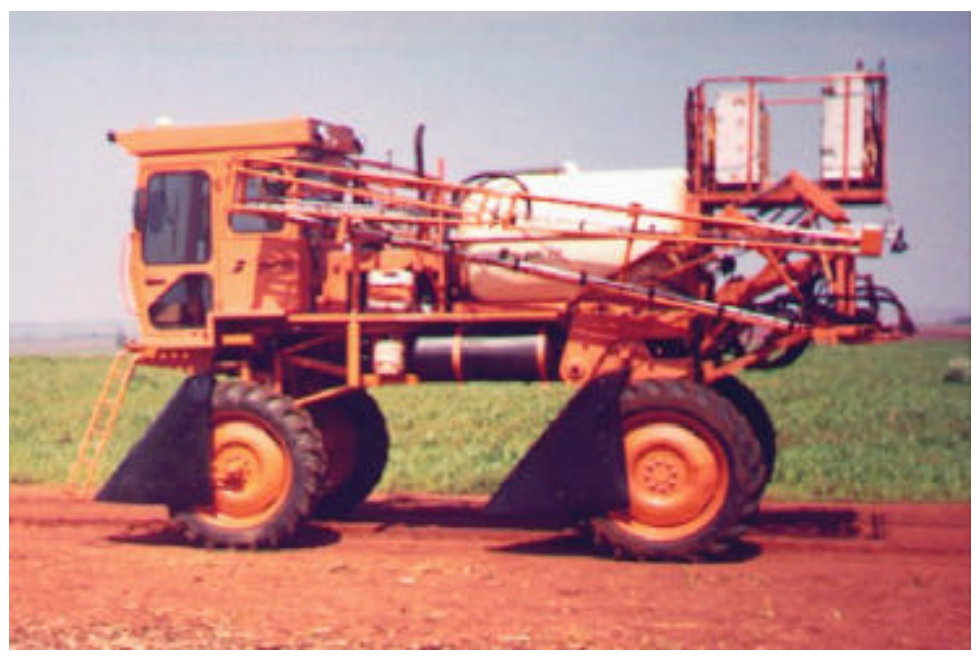

(a)

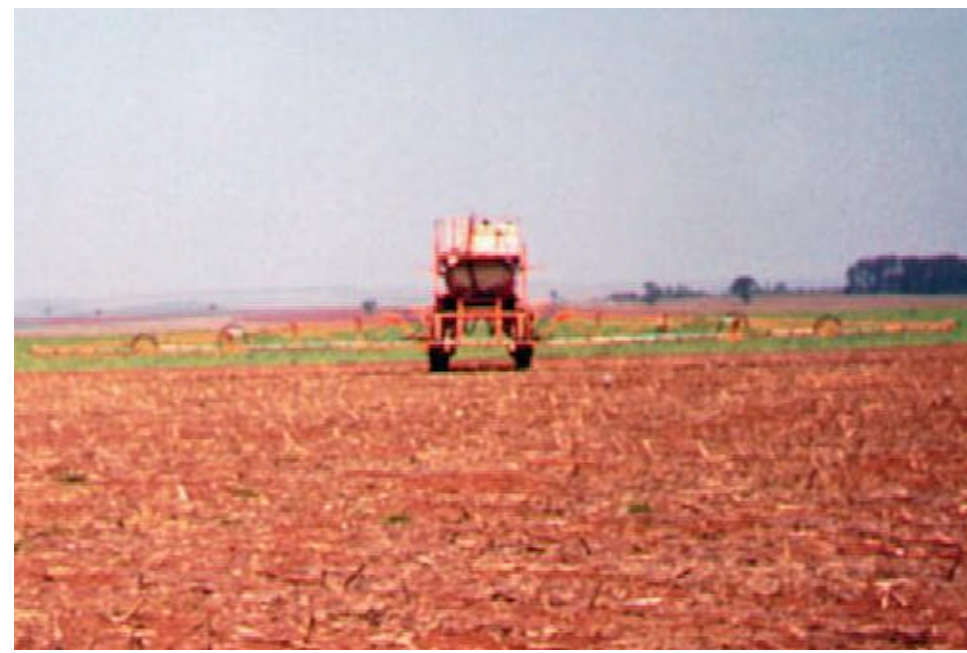

(b)

Figura 11 - Vistas lateral (a) e traseira (b) do protótipo do pulverizador automotriz utilizado neste estudo. 
Este protótipo foi fabricado pela Empresa Jacto e foi baseado no modelo de pulverizador automotriz Uniport 2000. Sobre este pulverizador foi instalado o sistema de injeção direta de defensivos MidTech TASC 6600.

O pulverizador automotriz possui barras de 21,5 $\mathrm{m}$ de comprimento, com bicos pulverizadores espaçados a $0,50 \mathrm{~m}$. O reservatório de água para calda possui capacidade para 20001 . O modelo da bomba principal do pulverizador instalado foi a JP150, que possui capacidade de recalque nominal de $2,51 . \mathrm{s}^{-1}\left(1501 . \mathrm{min}^{-1}\right)$ a $540 \mathrm{rpm}$. A barra do pulverizador possui altura regulável de 0,5 a 1,8 m por acionamento hidráulico, todas as operações foram realizadas com a barra a $0,5 \mathrm{~m}$ do alvo de interesse. As aplicações foram realizadas com o motor do pulverizador automotriz sendo acionado na rotação nominal de $1600 \mathrm{rpm}$, possibilitando uma estabilidade maior na velocidade do pulverizador, desejável principalmente para a determinação do tempo de resposta do sistema para aplicação localizada de defensivos.

O bico pulverizador utilizado foi o $110^{\circ}$-LD-03 de Kematal da Albuz, que proporciona uma distribuição do jato plano (leque) elíptico e com ângulo de $110^{\circ}$. Estes bicos foram instalados em porta-bicos com válvula antigotejo.

Para o alinhamento paralelo das aplicações pelo pulverizador foi utilizado um marcador de linha por espuma Jacto, modelo Mastermark. Os flocos de espuma foram constituídos pela solução de agente espumante, AG-2, diluído na concentração de $5 \%$ em água potável.

\subsection{Sistema de injeção direta de defensivos}

Nos ensaios da determinação do tempo de resposta e da aplicação localizada de defensivos foi utilizado o sistema de injeção direta de defensivos MidTech TASC 6600 com uma interface eletrônica para o sistema computacional. Este sistema, instalado sobre o pulverizador automotriz, é idêntico àquele ilustrado na Figura 5.

O sistema consiste em seis conjuntos individuais compostos por bombas peristálticas, por motores elétricos, por válvulas, por sensores de pressão e vazão, por reservatórios para os produtos químicos, como também possui válvulas, sensores de vazão, pressão e velocidade para o sistema principal do pulverizador e um sistema 
eletrônico microprocessado como controlador central. Com esta configuração, o sistema para injeção direta de defensivos pode efetuar a aplicação de seis produtos diferentes simultaneamente, porém, somente um conjunto foi utilizado para a realização do presente trabalho.

A vazão do sistema é mantida automaticamente constante, de acordo com a velocidade do pulverizador, as secções ativas da barra e a pressão do sistema principal. A variação do fluxo de injeção de defensivo no sistema principal do pulverizador é realizada pela variação da rotação da bomba injetora.

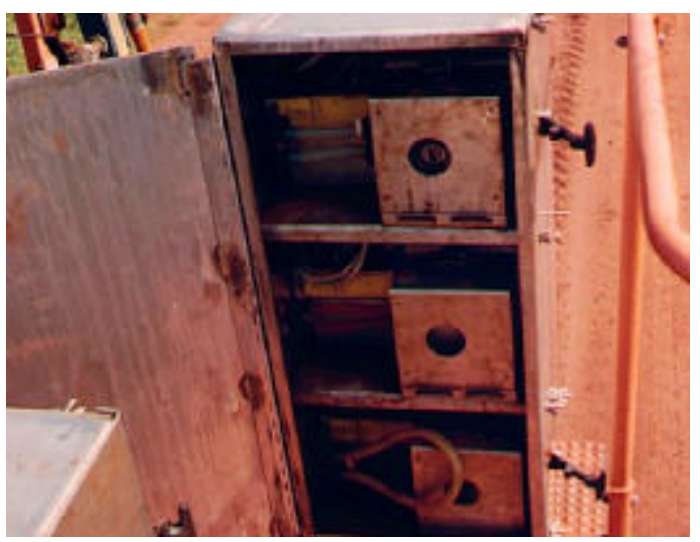

(a)

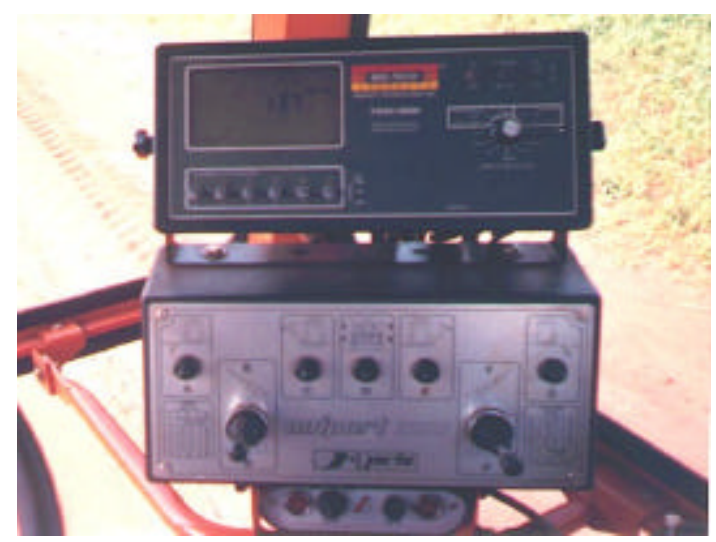

(c)

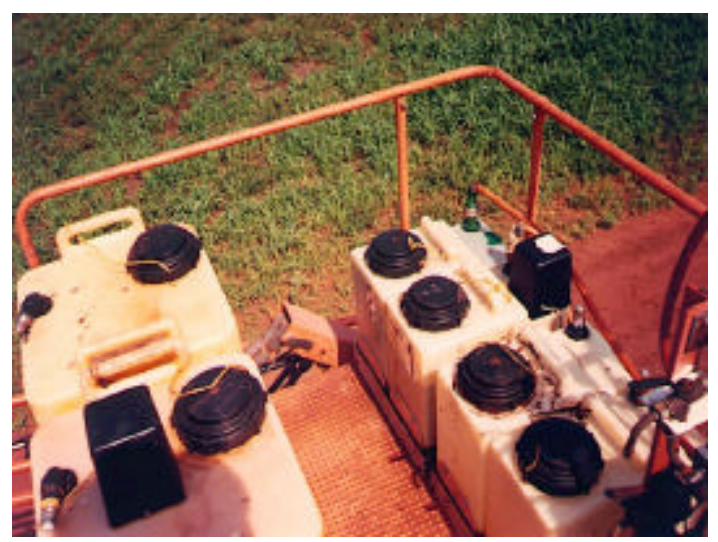

(b)

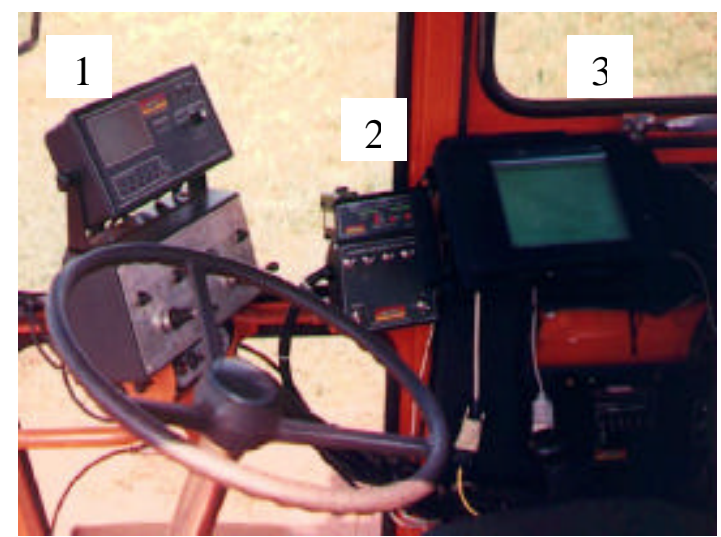

(d)

Figura 12 - Ilustração das bombas peristálticas (a), dos reservatórios de defensivos (b), do controlador microprocessado (c) e vista geral do sistema eletrônico com o controlador microporcessado (1), a interface (2) e o computador portátil (3) (d). 


\subsubsection{Calibração do sistema}

O sistema para aplicação localizada de defensivos instalado no pulverizador automotriz foi calibrado visando a aplicação do herbicida na velocidade de $2,78 \mathrm{~m} \cdot \mathrm{s}^{-1}$ $\left(10 \mathrm{~km} \cdot \mathrm{h}^{-1}\right)$, a variação de dosagens aplicado pelo sistema de injeção entre 1 e $61 . \mathrm{ha}^{-1} \mathrm{de}$ herbicida, a aplicação de 1501. ha $^{-1}$ de calda e a uma pressão de operação de $207 \mathrm{kPa}$ (30 lbf.pol ${ }^{2}$ ). Todas estas calibrações foram efetuadas embasadas no manual técnico do fabricante do sistema de injeção direta de defensivos.

\subsubsection{Pré-ensaio para a verificação do funcionamento do sistema}

Foi realizado um pré-ensaio para a verificação do funcionamento do sistema. Este foi efetuado num pátio com área suficiente para o percurso do pulverizador automotriz por uma distância de $200 \mathrm{~m}$ na velocidade de $2,78 \mathrm{~m} \cdot \mathrm{s}^{-1}\left(10 \mathrm{~km} \cdot \mathrm{h}^{-1}\right)$.

Foi criado um mapa de prescrição fictício com dosagens diferentes. O préensaio foi realizado apenas com água em todo o sistema, tanto no tanque principal do pulverizador, quanto nos reservatórios das bombas peristálticas do sistema de injeção de defensivos.

Foi observada neste pré-ensaio a variação automática da dosagem aplicada pelo sistema de injeção direta de defensivos pela visualização na tela do controlador do sistema MidTech, seguindo as dosagens do mapa de prescrição, possibilitando a verificação da adequada calibração e configuração de todo o sistema.

\subsection{Herbicidas}

No ensaio onde houve a determinação do tempo de resposta do equipamento para aplicação localizada de defensivos foi utilizada a mistura de herbicidas Diurom+Paraquat (Gramocil), pois possui ação rápida sobre as plantas, possibilitando a verificação do resultado da aplicação no dia seguinte à operação. Esta é uma mistura de herbicidas de ação total não seletiva aplicada em pós-emergência (Rodrigues \& 
Almeida, 1998). Para o manejo em plantio direto é recomendada a dosagem de 2,0 1.ha ${ }^{-1}$ do produto comercial.

No ensaio onde foi realizada a aplicação localizada de defensivos foi utilizado o herbicida Glyphosate (RoundUp), pois é indicado para o controle das espécies de plantas daninhas presentes na área experimental. Este herbicida é recomendado para o controle não seletivo de mono e dicotiledôneas em pós-emergência de diversas culturas e para o manejo do sistema de plantio direto (Rodrigues \& Almeida, 1998). As dosagens recomendadas deste produto comercial podem variar deste 0,5 a 6,0 1.ha ${ }^{-1}$, dependendo das espécies de plantas daninhas presentes e dos seus estágios de desenvolvimento.

\subsection{Ensaio para determinação do tempo de resposta do sistema}

O ensaio para a determinação do tempo de resposta total do sistema para aplicação localizada de defensivos foi realizada em condição dinâmica e sem a necessidade da instrumentação do pulverizador automotriz por sensores adicionais. A metodologia foi baseada no princípio da comparação entre a localização da mancha onde houve a aplicação do herbicida e a localização da mancha onde foi planejada a aplicação do herbicida (Paice et al. 1997).

Por esta metodologia, a área experimental, que estava sendo cultivada com milheto, foi subdividida numa grade retangular de células de 21 x $25 \mathrm{~m}$ com o auxílio do programa Farm Site Mate. Foi então elaborado o mapa de prescrição para a aplicação do herbicida Diurom+Paraquat (Gramocil) em duas quadrículas consecutivas desta gade. Ao longo do percurso planejado do pulverizador, foram demarcados 5 pontos, correspondentes ao ponto inicial do percurso $(0 \mathrm{~m})$, ao ponto inicial da injeção do defensivo no sistema (30,6 m), ao ponto inicial da aplicação do herbicida no campo (100 $\mathrm{m})$, ao ponto final da aplicação do herbicida no campo $(150 \mathrm{~m})$ e ao ponto final do percurso $(250 \mathrm{~m})$. A materialização destes pontos por estacas objetivou a visualização do alinhamento do pulverizador durante a aplicação.

O cálculo das posições destes pontos no trajeto planejado do pulverizador foi baseado no instante em que cada fenômeno ocorreria a partir do início do trajeto, de acordo com o tempo de resposta teórico do sistema. Este tempo de resposta teórico (s) 
foi calculado baseando-se no volume de calda (1) para o preenchimento das tubulações do pulverizador desde o ponto de injeção do defensivo no sistema até as barras, na vazão de calda planejada $\left(1 . h a^{-1}\right)$ e na capacidade de campo do pulverizador (ha. $\mathrm{s}^{-1}$ ).

\subsubsection{Aplicação do defensivo segundo o mapa de prescrição para determinação do tempo de resposta}

Após a obtenção do mapa de prescrição foi realizada a aplicação do herbicida sobre o percurso planejado na velocidade constante de $2,78 \mathrm{~m} \cdot \mathrm{s}^{-1}\left(10 \mathrm{~km} \cdot \mathrm{h}^{-1}\right) \mathrm{e}$ com o tempo de resposta teórico determinado (25 s). Adotou-se que não houve variações de velocidade do pulverizador automotriz no trajeto planejado, pois a área é plana, com terreno regular e o motor do pulverizador automotriz foi mantido constante no percurso na rotação nominal de $1600 \mathrm{rpm}$. A regularização da velocidade do pulverizador automotriz foi realizada $100 \mathrm{~m}$ antes do ponto inicial do percurso planejado do pulverizador, ou seja, o pulverizador iniciou o trajeto sobre o percurso planejado em condição dinâmica e com velocidade constante. A velocidade de deslocamento pôde ser visualizada em tempo real na tela do controlador MidTech TASC 6600.

Antes da execução do ensaio propriamente dito, o sistema de injeção de defensivos do pulverizador foi acionado por um minuto para o preenchimento das tubulações pelo herbicida até o ponto de injeção. Então, o sistema de injeção foi desativado, mantendo-se a bomba do pulverizador e a aplicação da calda acionadas por mais um minuto, possibilitando a eliminação do herbicida do sistema desde o ponto de injeção até os bicos.

Após esta etapa, foi realizada a aplicação do herbicida sobre o campo cultivado com milheto. Desde o início do trajeto o pulverizador automotriz aplicou somente água sobre o campo. Ao passar pelo ponto 2, ilustrado na Figura 13, o sistema MidTech iniciou a injeção do defensivo no sistema pelo período de tempo suficiente para a aplicação sobre $50 \mathrm{~m}$ (duas quadrículas consecutivas da grade do mapa de prescrição), quando então foi interrompida a injeção do defensivo e o pulverizador voltou a aplicar some nte água. 


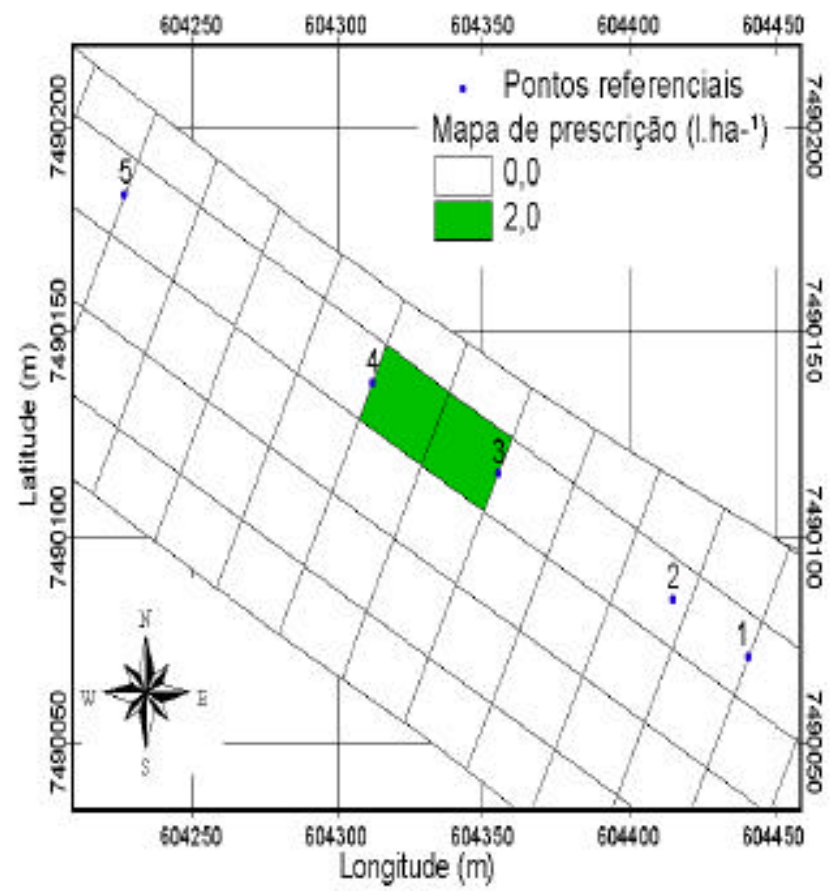

Figura 13 - Mapa de prescrição para o ensaio do tempo de resposta do equipamento para aplicação localizada de defensivos e trajeto planejado do pulverizador materializado pelos pontos referenciais.

\subsubsection{Cálculo do tempo de resposta do sistema}

Após a ação do herbicida dessecante, foi realizado o mapeamento da mancha correspondente as plantas mortas pela ação do herbicida. Se o tempo de resposta do sistema fosse exatamente de $25 \mathrm{~s}$, a mancha mapeada coincidiria exatamente com o mapa de prescrição.

A diferença de posicionamento entre a mancha mapeada e o mapa de prescrição permitiu calcular o tempo de resposta do sistema, nas condições em que foi realizada a aplicação. Com o auxílio do programa de SIG SSToolbox para a sobreposição dos mapas foi calculado o tempo de resposta do sistema para toda a extensão da barra do pulverizador. Então, a cada 1,39 m do trajeto do pulverizador (a cada $0,5 \mathrm{~s}$ de seu trajeto) foi traçada uma linha perpendicular ao alinhamento do trajeto. Nestas linhas foram calculadas as porcentagens das manchas onde houve a ação do herbicida naquele alinhamento perpendicular $(\mathrm{m})$ em relação a largura total da faixa de 
aplicação $(21,5 \mathrm{~m})$. Esta porcentagem da mancha onde houve a ação do herbicida corresponde, na prática, à porcentagem da barra do pulverizador que estava efetivamente aplicando o herbicida naquele instante.

Foi elaborado um gráfico ilustrando a eficiência da faixa de deposição de herbicida a cada segundo, desde o momento no qual a mudança na dose foi solicitada. A eficiência da faixa de deposição é a razão entre a largura efetiva da barra aplicando herbicida naquele instante e a largura total da barra do pulverizador.

O tempo de resposta considerado para a aplicação localizada de defensivos foi aquele correspondente a $95 \%$ da eficiência da faixa de deposição, pois foi considerada a sobreposição de $1 \mathrm{~m}$ da faixa de aplicação do herbicida durante a pulverização, garantindo a não ocorrência de falhas na aplicação devido ao alinhamento falho do pulverizador.

\subsection{Mapeamento de plantas daninhas e dos atributos da fertilidade do solo}

Os mapeamentos foram realizados com o auxílio do programa Farm Site Mate conectado ao DGPS. Todos os mapas gerados foram georreferenciados segundo o datum WGS-84. Estes mapas possuíam coordenadas geográficas que foram transformadas para o sistema de coordenadas UTM (Universal Transverso de Mercator). Todos os mapas ilustrados neste trabalho estão georreferenciados no sistema de coordenadas UTM.

Nos casos onde houve a geração dos mapas por interpolações de valores de uma grade amostral e onde estes pontos amostrais estavam localizados muito próximos aos limites da área experimental (distâncias menores que $3 \mathrm{~m}$ da bordadura) houve a necessidade do reposicionamento deste ponto para uma localização mais distante dos limites da área, dentro da mesma célula da grade amostral. Este procedimento melhora a qualidade da análise geoestatística e do mapa de planta daninha, pois possibilita a aquisição e a análise de dados numa escala menor do que a distância interamostral. 


\subsubsection{Mapeamento de plantas daninhas}

Durante o mapeamento das plantas daninhas, a identificação das espécies foi realizada com o auxílio do Manual de Identificação e Controle das Plantas Daninhas (Lorenzi, 1998).

\subsubsection{Mapeamento de plantas daninhas pela metodologia das amostragens sistemáticas}

O mapeamento de plantas daninhas pela metodologia das amostragens sistemáticas consistiu-se em coletar as informações sobre as espécies presentes, o estágio de desenvolvimento e sobre a densidade de ocorrência numa área amostral georreferenciada de $0,25 \mathrm{~m}^{2}$, em cada ponto da grade amostral de $25 \times 25 \mathrm{~m}$ previamente estabelecida (140 pontos amostrais). Cada espécie de planta daninha presente na área amostral foi enquadrada num estágio de desenvolvimento: 3 folhas, 5 folhas, 8 folhas, planta adulta, planta florescendo e planta com fruto. Este procedimento possibilitou a identificação de manchas de plantas daninhas da mesma espécie, porém, em estágios de desenvolvimento diferentes. As informações foram anotadas numa planilha. A Figura 14 ilustra a disposição dos pontos amostrais georreferenciados utilizados para o mapeamento de plantas daninhas por esta metodologia. 


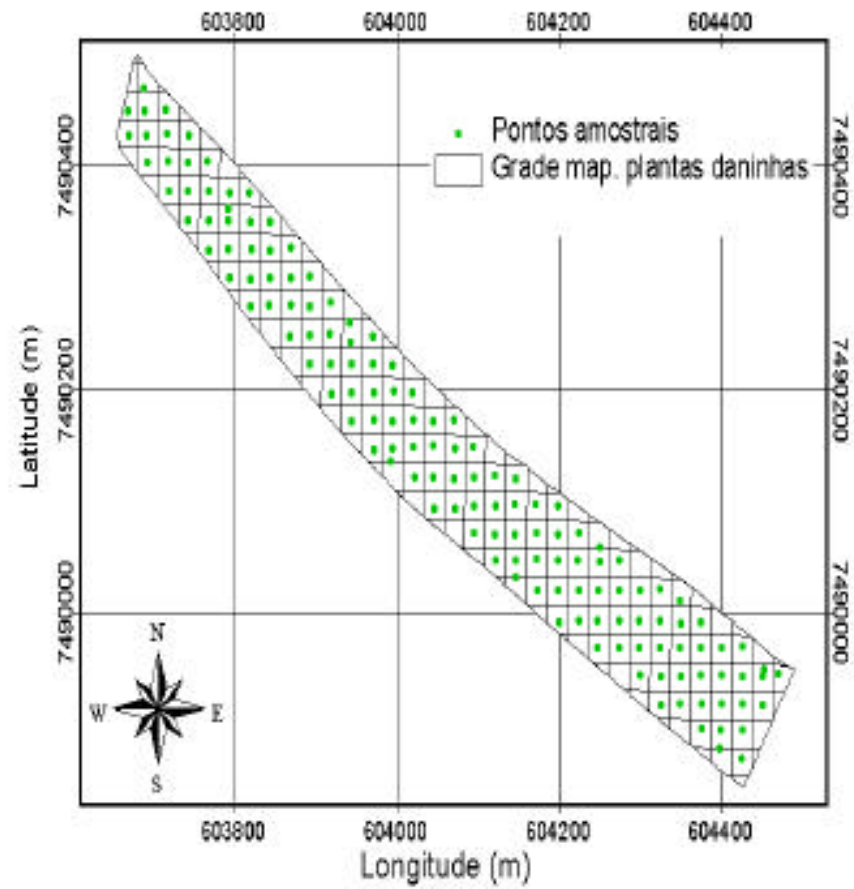

Figura 14 - Configuração da grade amostral para o mapeamento de plantas daninhas pela metodologia das amostragens sistemáticas.

A grade foi gerada numa etapa anterior ao mapeamento com o auxílio do programa Farm Site Mate. Foi utilizado o DGPS para auxiliar na navegação até o ponto amostral.

As informações tomadas nos pontos amostrais foram asociadas as suas respectivas coordenadas geográficas com o auxílio de uma planilha eletrônica.

\subsubsection{Mapeamento de plantas daninhas pela metodologia do contorno das manchas de ocorrência}

A metodologia utilizada para o mapeamento de plantas daninhas pelo contorno das manchas foi aquela sugerida por Balastreire \& Baio (2001a), onde os perímetros das manchas de ocorrência das plantas daninhas foram percorridos, mapeando-as com o auxílio do DGPS e anotando-se as espécies de plantas daninhas presentes e o seu estágio de desenvolvimento. 
A identificação das manchas das plantas daninhas foi um processo visual pela localização das espécies que ocorriam em maior densidade.

Foi utilizado um trator agrícola Massey Ferguson, modelo 275, para facilitar

o deslocamento pelo campo durante a operação de mapeamento e para facilitar a visualização das manchas de plantas daninhas devido a altura num nível maior em relação ao nível do solo. Este trator foi instrumentado com o DGPS Trimble AG 132 e o computador portátil Fujitsu, contendo o programa de navegação e de mapeamento Farm Site Mate.

Foi gerada uma grade de células de 1 ha numa etapa anterior ao mapeamento, facilitando o processo pela visualização dos locais já mapeados na tela do computador portátil.

Os dados anotados foram associados as manchas de plantas daninhas georreferenciadas através do programa de SIG SSTolbox. Este processo possibilitou a obtenção dos mapas das espécies de plantas daninhas mapeadas separadamente, sem a necessidade de análises adicionais.

\subsubsection{Mapeamento dos atributos da fertilidade do solo}

O mapeamento dos atributos da fertilidade do solo foi realizado no mesmo período em que foram efetuados os mapeamentos de plantas daninhas. Este mapeamento foi executado em pontos georreferenciados da grade amostral de 50 x $50 \mathrm{~m}$, perfazendo 40 amostras na área experimental. Em cada ponto amostral foram coletadas 6 subamostras num raio máximo de $1 \mathrm{~m}$ ao redor do ponto central georreferenciado, totalizando uma amostra composta. Cada ponto da grade amostral do mapeamento de fertilidade do solo coincidiu com um ponto amostral do mapeamento das plantas daninhas. A Figura 15 ilustra a disposição dos pontos amostrais georreferenciados utilizados para o mapeamento de atributos da fertilidade do solo. 


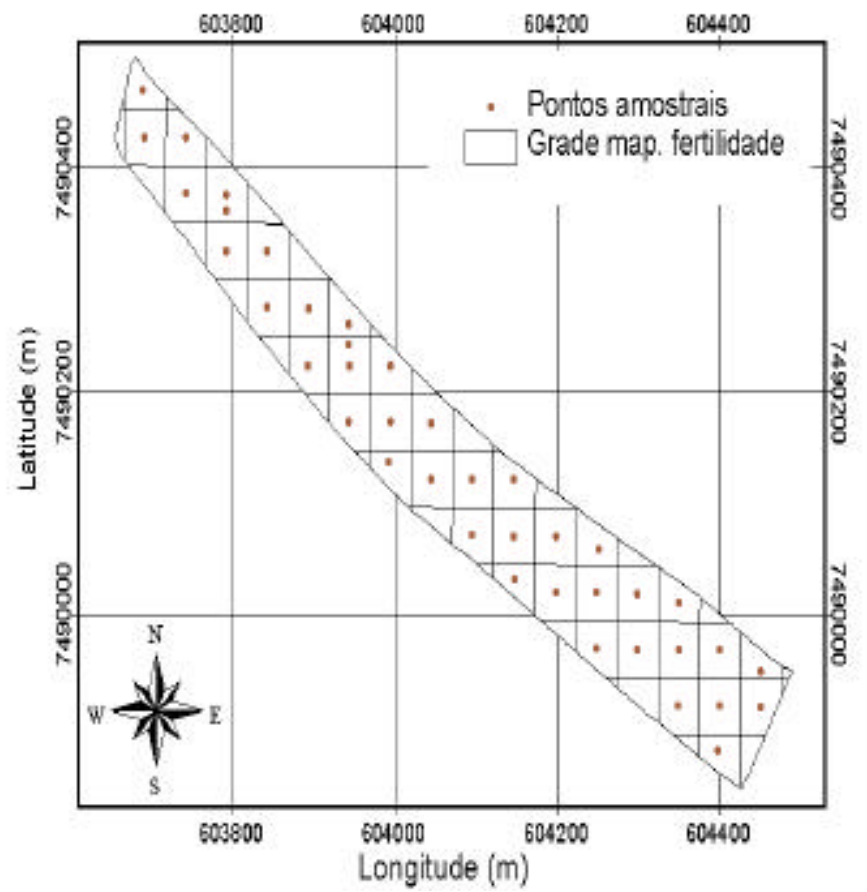

Figura 15 - Configuração da grade amostral para o mapeamento de atributos da fertilidade do solo por amostragens sistemáticas.

O mapeamento de fertilidade foi realizado pela coleta de amostras de solo a 0-20 cm com o auxílio de um trado. As sub-amostras foram homogeneizadas e foram colocadas num saco plástico específico para amostras de solo, identificados pelo identificador do ponto amostral.

Para a realização do referido mapeamento, o DGPS e o computador portátil foram carregados numa mochila.

As amostras de solo foram enviadas para o laboratório da Fundação Shunji Nishimura de Tecnologia para análises químicas. Foram realizadas as análises químicas dos macro e micronutrientes de cada amostra. A metodologia para a extração e análise dos teores dos nutrientes utilizada por este laboratório segue o padrão IAC (Instituto Agronômico de Campinas).

Os resultados das análises das amostras de solo foram compilados para a planilha eletrônica, associando-os às respectivas coordenadas geográficas dos pontos amostrais. 


\subsubsection{Análise dos dados}

\subsubsection{Análise estatística dos dados amostrados}

Procedeu-se a análise estatística dos dados coletados pelas metodologias de mapeamentos por amostragens para a verificação de seu comportamento quanto às medidas estatísticas de posição e de dispersão, antes de submetê-los à análise geoestatística. Todas as análises estatísticas foram realizadas pelo programa SAS.

Foram realizadas as análises de medidas de posição (média, valores máximo e mínimo, quartis superior e inferior), de dispersão (desvio padrão e variância) e da forma da dispersão (simetria e curtose). O cálculo dos momentos de terceira e de quarta ordens (simetria e curtose) permitiu a caracterização das curvas normais das variáveis mensuradas.

Com a finalidade da realização das análises estatística e geoestatística, os dados referentes ao estágio de desenvolvimento obtidos no mapeamento de plantas daninhas por amostragens sistemáticas foram transformados em variáveis contínuas.

O cálculo dos quartis da distribuição dos valores das variáveis mensuradas auxiliou na identificação dos dados discrepantes da distribuição normal (“outliers”). O cálculo para a identificação dos dados candidatos a dados discrepantes foi realizado pelo critério dos limites inferior e superior de uma distribuição normal (Libardi et al., 1996 e Gonçalves et al., 1999). Os limites superior e inferior foram obtidos pelas equações:

$$
\begin{aligned}
& A I=Q S-Q I \\
& L S=Q S+(1,5 * A I) \\
& L I=Q I-(1,5 * A I)
\end{aligned}
$$

sendo,

$A I$ é a Amplitude Interquartil;

$L S$ é o Limite Superior;

$L I$ é o Limite Inferior;

$Q S$ e $Q I$ são os Quartis Superior e Inferior.

Os dados que não se enquadravam entre os limites inferior e superior foram considerados dados discrepantes. 


\subsubsection{Análise geoestatística dos dados amostrados}

A análise geoestatística foi realizada pelo programa GS+. Submeteram-se para a análise geoestatística somente aqueles atributos que ocorriam em um número maior que 20 pontos amostrais. Adotou-se este critério para proporcionar maior confiabilidade nas análises geoestatísticas. De posse dos dados das variáveis mapeadas (plantas daninhas e fertilidade) foram obtidos os semivariogramas experimentais. A estes semivariogramas experimentais foram ajustados os semivariogramas teóricos. Os semivariogramas teóricos são curvas ajustadas que proporcionam a máxima correlação entre os pontos dos semivariogramas experimentais. O programa GS+ realizou a escolha do melhor modelo do semivariograma teórico baseado na minimização das soma dos quadrados dos resíduos, em relação aos pontos do semivariograma experimental. Foram avaliados os modelos de semivariogramas esférico, exponencial, gaussiano e linear. Foram analisados os modelos dos semivariogramas isotrópicos e anisotrópicos para as variáveis mensuradas.

Os modelos dos semivariogramas teóricos ajustados foram selecionados através da análise de alguns fatores. O valor do coeficiente de correlação, obtido pela validação cruzada (valores lidos versus valores estimados), foi o fator que mais influenciou na escolha do modelo (Vieira, 1995). Em caso de igualdade entre os resultados da validação cruzada, o modelo escolhido foi o que possuía o menor efeito pepita, pois este fator ilustra o quanto da variabilidade espacial não está sendo descrito pelo modelo.

Após o ajuste dos semivariogramas teóricos foram tomados todos os parâmetros necessários para a realização da interpolação dos mapas pelo processo de krigagem.

Também foi calculada a relação entre o efeito pepita e o patamar $(\mathrm{Co} / \mathrm{Co}+\mathrm{C})$ para cada modelo ajustado. Esta relação mede o grau da dependência espacial do atributo amostrado (Cambardella et al., 1994). O grau de dependência espacial pode ser classificado como: forte, quando o semivariograma apresentar efeito pepita menor ou igual a $25 \%$ do patamar; moderado, quando esta relação estiver entre 25 e $75 \%$; fraco, 
quando o efeito pepita foi superior a 75\% do patamar. Assim, quanto menor esta relação, menos o efeito pepita está influenciando a dependência espacial dos dados.

\subsubsection{Interpolação dos dados amostrados}

Os parâmetros dos modelos dos semivariogramas obtidos pela análise geoestatística foram utilizados para a realização da interpolação dos dados por krigagem. O tipo de krigagem escolhido para a realização da interpolação das variáveis mapeadas foi a krigagem ordinária em blocos 4 x 4. A krigagem ordinária leva em consideração a estacionaridade (dispersão em torno da média homogênea) somente nas vizinhanças do ponto amostrado (hipótese intrínseca), sem a perda de informações em relação a krigagem simples. A krigagem em blocos é mais adequada, pois não perde em qualidade em relação a krigagem pontual, reduz a variância de krigagem e proporciona uma estimativa mais confiável (Gonçalves et al., 1999). Os mapas foram elaborados em formato matricial ("raster") com células de 10 x $10 \mathrm{~m}$ e foram georreferenciados no sistema de coordenadas UTM.

Para o cenário onde as espécies de plantas daninhas mapeadas ocorreram em um número menor do que vinte pontos amostrais, escolheu-se o método de interpolação pelo inverso do quadrado da distância. Este método de interpolação, dentre os que não consideram a dependência espacial entre as amostras, proporciona um resultado semelhante ao da krigagem (Golden Software, 1995).

\subsection{Aplicação localizada de defensivos}

\subsubsection{Elaboração dos mapas de prescrição}

Para a elaboração do mapa de prescrição utilizado na aplicação localizada de defensivos foram sobrepostos os mapas das plantas daninhas no programa de SIG SSToolbox.

Nesta etapa, foram utilizados os mapas de plantas daninhas obtidos pela metodologia de mapeamento pelo contorno das manchas de ocorrência. Estes mapas não precisaram de tratamento e análises adicionais, tornando-os prontamente disponíveis 
após a execução do mapeamento. Este fator é importante pois a população das plantas daninhas possui um dinamismo quanto ao seu desenvolvimento (estágio de desenvolvimento e colonização de novas áreas), podendo tornar o mapa de planta daninha inválido para a criação de um mapa de prescrição a ser utilizado no mesmo ciclo da cultura.

A grade com células de 20 × 20 metros foi gerada com o auxílio do programa de SIG SSToolbox. As dimensões desta grade foram definidas em função do comprimento da barra do pulverizador e da sobreposição planejada durante a aplicação.

A cada célula do mapa de prescrição foi atribuída manualmente uma

dosagem de herbicida, de acordo com as espécies presentes e o estágio de desenvolvimento de cada planta daninha que ocorria naquela célula. As dosagens do herbicida Glyphosate foram selecionadas considerando-se a variabilidade espacial das espécies de plantas daninhas presentes, o estágio de desenvolvimento de cada espécie, a recomendação do fabricante do herbicida e a recomendação sugerida por Rodrigues \& Almeida (1998).

\subsubsection{Execução da aplicação localizada de defensivos}

Para a realização da aplicação localizada de defensivos a interface do sistema MidTech foi conectada via porta serial com o computador portátil. Por esta interface, o programa Farm Site Mate controlou as dosagens aplicadas pelo sistema MidTech de acordo com o mapa de prescrição gerado previamente. Nesta etapa, foi considerado o tempo de resposta do sistema para aplicação localizada de defensivos, determinado no ensaio específico para este fim. O programa Farm Site Mate foi configurado com o tempo de adiantamento ("look ahead") exatamente igual ao tempo de resposta do sistema.

A pulverização foi realizada na velocidade de $2,78 \mathrm{~m} \cdot \mathrm{s}^{-1}\left(10 \mathrm{~km} \cdot \mathrm{h}^{-1}\right)$, com

um volume de calda de 150 1.ha ${ }^{-1}$ e na pressão de operação de 207 kPa (30 lbf.pol²). As manobras do pulverizador durante a aplicação foram realizadas fora dos limites da área experimental. 
Foi calculado o volume utilizado do herbicida, comparando-se este resultado ao volume de herbicida utilizado quando aplicado nas mesmas condições, porém, em área total e em dosagem única.

\subsubsection{Geração e correção do mapa da aplicação}

Durante a aplicação localizada de defensivos o programa Farm Site Mate gerou o mapa da aplicação ("as-applied"). O mapa da aplicação corresponde a dosagem pontual de herbicida que o sistema de injeção direta de defensivos aplicou naquele instante. Com o mapa da aplicação é possível verificar se o sistema realmente aplicou a dosagem recomendada naquele local do campo, segundo o mapa de prescrição.

Porém, o mapa de aplicação gerado pelo programa Farm Site Mate não considera o tempo de resposta do sistema para a elaboração do mesmo. O mapa da aplicação elaborado pelo programa ilustra as dosagens do defensivo que foram injetadas no sistema naquele instante, sendo necessária a realização de uma correção deste mapa. Esta correção foi realizada segundo o tempo de resposta do sistema e a velocidade de aplicação desenvolvida pelo pulverizador. A dosagem do defensivo num determinado ponto georreferenciado foi transferida para o ponto a frente, correspondente à distância percorrida pelo pulverizador naquele trajeto, de acordo com a velocidade e o tempo de resposta.

\subsubsection{Verificação do resultado da aplicação localizada}

Após a ação total do herbicida sobre as plantas daninhas, que ocorreu 15 dias após a aplicação do herbicida, foi possível a realização de um mapeamento das manchas das plantas daninhas que não foram eficientemente controladas.

Este mapeamento foi realizado percorrendo-se os perímetros das manchas de plantas daninhas com o sistema de localização conectado ao computador portátil. Este mapa foi comparado ao mapa de aplicação pela sobreposição dos mesmos. Foi determinada a área onde não houve um controle eficiente das plantas daninhas. 


\subsection{Comparação entre as metodologias utilizadas para o mapeamento de plantas daninhas}

Foi realizada a comparação entre as metodologias para o mapeamento de

plantas daninhas executadas neste trabalho: por amostragens sistemáticas e pelo contorno das manchas de plantas daninhas.

As metodologias foram comparadas quanto ao número de pessoas utilizadas, ao tempo necessário para a execução do trabalho de levantamento dos dados em campo, ao nível de detalhamento da variabilidade espacial dos mapas finais, a necessidade de análises adicionais (análises estatística e geoestatística), ao modo de geração e obtenção dos mapas finais, a possibilidade da realização em áreas extensas e a objetividade do método de levantamento dos dados em campo.

\subsection{Correlação entre os mapas de plantas daninhas e dos atributos da fertilidade do solo}

Procedeu-se a análise da correlação da variabilidade espacial existente entre os mapas de plantas daninhas e os mapas dos atributos da fertilidade do solo. Foram correlacionados os mapas dos atributos da fertilidade do solo com os mapas dos estágios de desenvolvimento das plantas daninhas com o intuito de verificar a correlação existente entre o nível da fertilidade química do solo e o desenvolvimento da planta daninha. Este estudo foi realizado visando a possibilidade do mapa de um atributo da fertilidade do solo fornecer subsídios para a elaboração de mapas de plantas daninhas ou mapas de prescrição de herbicidas.

Foram calculados os coeficientes de correlação de Pearson entre os mapas dos atributos da fertilidade do solo e os mapas dos estágios de desenvolvimento das espécies de plantas daninhas mapeadas pela metodologia das amostragens sistemáticas.

Os mapas interpolados foram correlacionados com o auxílio do programa estatístico SAS. 


\section{RESULTADOS E DISCUSSÃO}

\subsection{Tempo de resposta do equipamento utilizado}

\subsubsection{Determinação do tempo de resposta do equipamento para aplicação localizada de defensivos}

A Figura 16 ilustra o mapa de prescrição utilizado no ensaio do tempo de resposta do sistema de injeção direta de defensivos, os pontos referenciais utilizados para auxiliar no alinhamento do pulverizador e a mancha de milheto mapeada, onde houve a ação do herbicida dessecante. Com estas informações foi possível criar o gráfico ilustrado na Figura 17. 


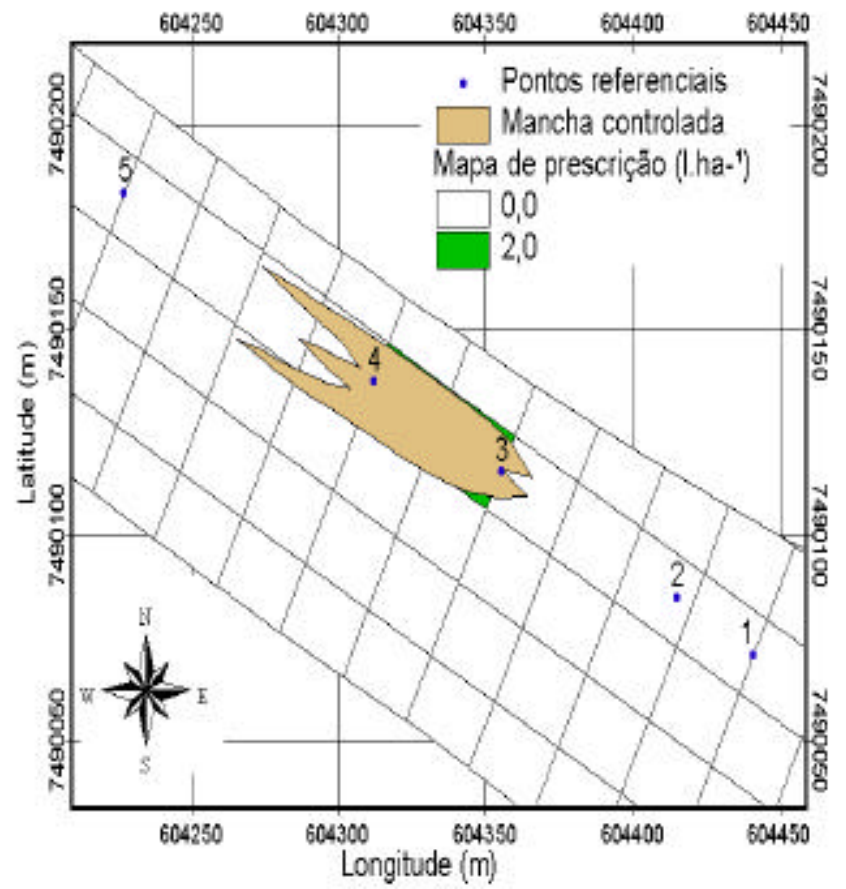

Figura 16 - Sobreposição do mapa de prescrição para a realização do ensaio do tempo de resposta, pontos referenciais e mancha mapeada onde houve a ação do herbicida.

Observou-se que no início e no final da mancha mapeada houve a formação de um "W", concordando com Nuspl et al. (1996). Isto deve-se à calda com o herbicida não preencher toda a barra do pulverizador num mesmo instante. Este fenômeno pode ser reduzido aumentando-se o número de secções da barra do pulverizador (Frost, 1990).

Como ilustra a Figura 17, a aplicação do herbicida pelas barras do pulverizador somente se iniciou $20 \mathrm{~s}$ após a ordem para a injeção do herbicida no sistema, o que corresponde ao percurso aproximado de $55 \mathrm{~m}$ na velocidade de $2,78 \mathrm{~m} . \mathrm{s}^{-}$ 1. Toda a extensão da barra do pulverizador somente foi preenchida pela calda com o herbicida aproximadamente $30 \mathrm{~s}$ após a ordem para a injeção do herbicida no sistema, correspondendo ao percurso aproximado de $85 \mathrm{~m}$. Não foi considerada nestes cálculos a curva de dose-resposta do herbicida. Como visto no item 2.11.2, o herbicida iniciou sua ação sobre o milheto mesmo antes de atingir a dosagem total (2 1.ha $\left.{ }^{-1}\right)$ (Paice et al., 1997). 
O tempo de resposta do sistema avaliado foi de 28 para as condições deste trabalho, que correspondeu ao tempo para a eficiência da faixa de deposição do herbicida atingir $95 \%$ da extensão da barra do pulverizador.

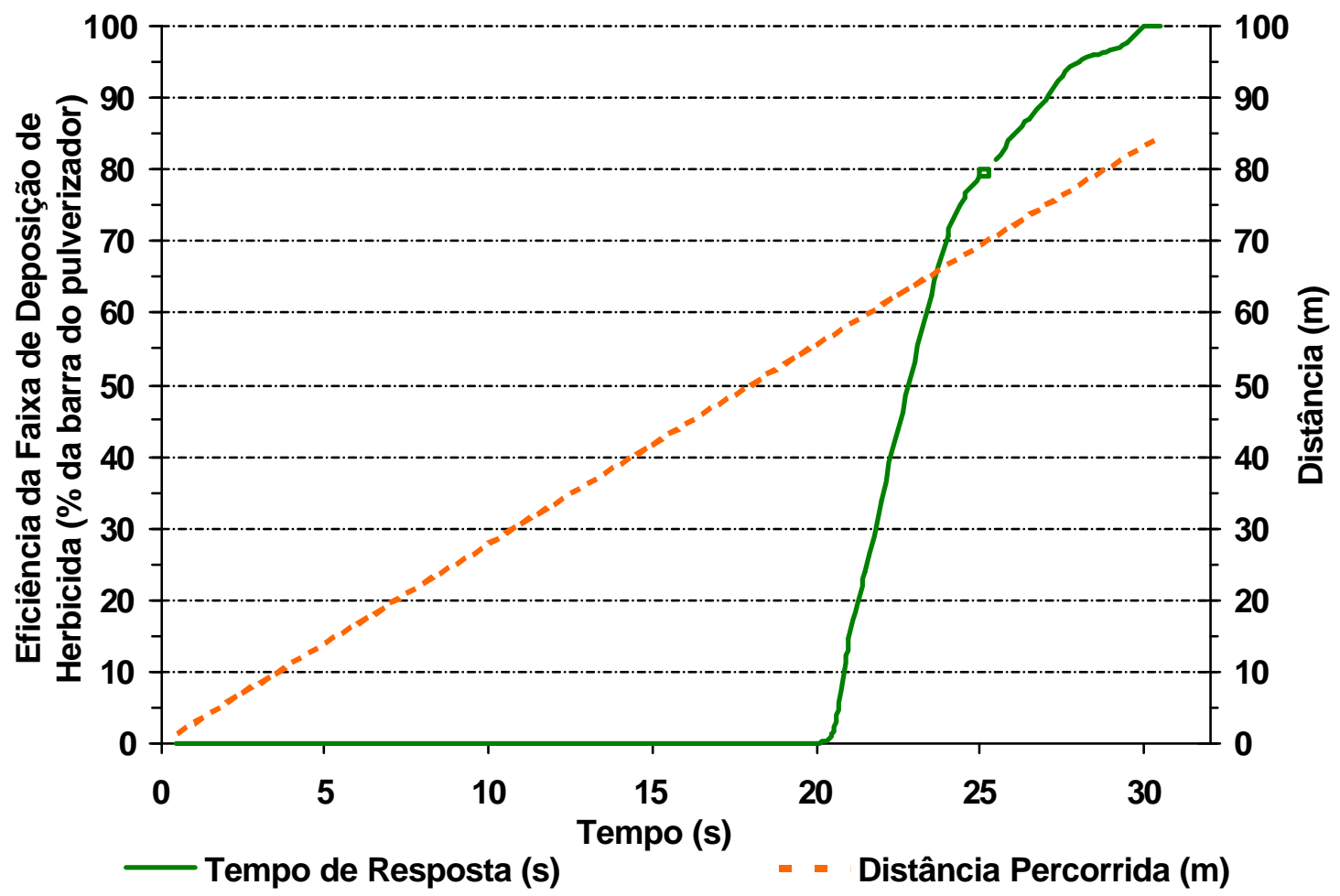

Figura 17 - Tempo de resposta do sistema de injeção direta de defensivos montado sobre o pulverizador automotriz para toda a extensão de sua barra, desde o instante $\mathrm{T}=0$, que representa o momento no qual a mudança da dose do herbicida foi solicitada $\left(01 . \mathrm{ha}^{-1}\right.$ para $\left.21 . \mathrm{ha}^{-1}\right)$.

Foi calculado o tempo de resposta para $95 \%$ da largura da barra pois foi considerada a sobreposição de aplicação do herbicida durante a pulverização $(0,5 \mathrm{~m}$ para cada lado da barra do pulverizador). Esta sobreposição é necessária para garantir a ausência de falhas no controle das plantas daninhas decorrentes da inexistência de paralelismo das faixas de aplicação durante a pulverização. 


\subsubsection{Avaliação da metodologia utilizada para a determinação do tempo de resposta}

A metodologia para determinação do tempo de resposta avaliada se mostrou prática e rápida, não sendo necessária a instrumentação do pulverizador para a sua execução (Antuniassi et al., 1997).

A aplicação do herbicida num campo com vegetação densa (milheto) propiciou a nítida visualização da mancha onde houve a ação do herbicida (Figura 18).

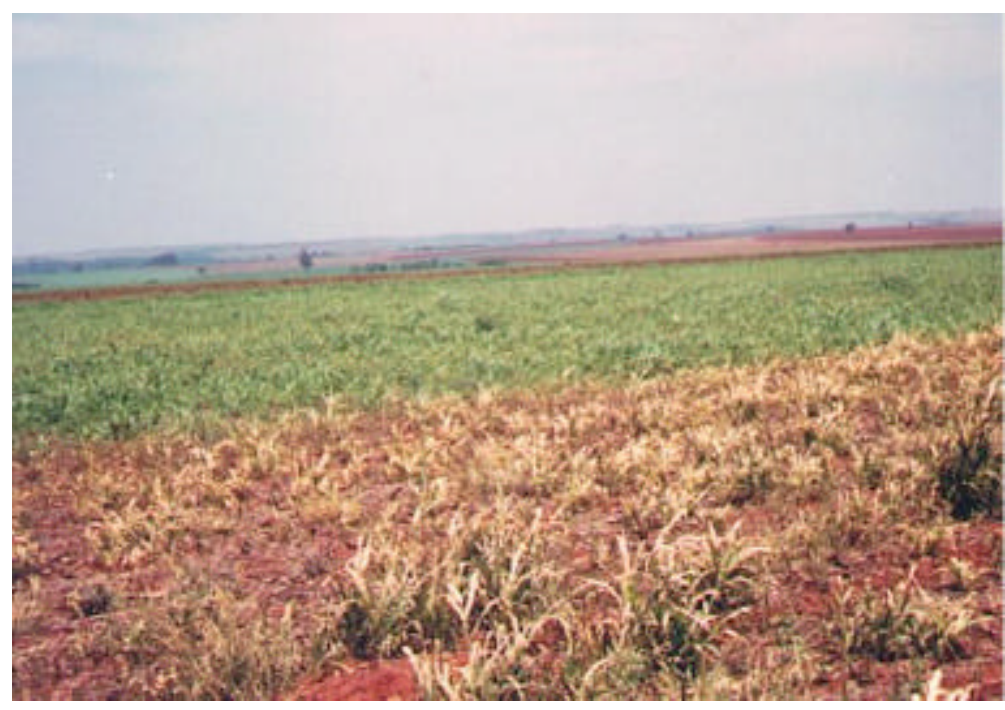

Figura 18 - Transição entre a mancha controlada de milheto e a área não controlada no ensaio para determinação do tempo de resposta.

\subsection{Análise dos dados obtidos pelas metodologias das amostragens de plantas daninhas e dos atributos da fertilidade do solo}

As análises foram realizadas para todos os atributos do mapeamento da fertilidade do solo. Porém, após o mapeamento das plantas daninhas pelo método das amostragens sistemáticas, foi verificado que somente quatro espécies ocorriam em um número de pontos amostrais suficientes para a realização de uma análise geoestatística confiável, sendo elas as espécies: capim carrapicho (Cenchrus echinatus), leiteiro (Ephorbia heterophylla), macelinha (Gnaphalium spicatum) e picão preto (Bidens pilosa). Estas espécies ocorreram em um número maior do que vinte pontos amostrais permitindo a realização da análise geoestatística. Outras duas espécies ocorreram num 
número menor do que vinte pontos amostrais: amargoso (Digitaria insularis) e buva (Conyza bonariensis). No entanto, foi possível a obtenção dos mapas destas espécies utilizando o processo de interpolação pelo inverso do quadrado da distância.

O Quadro 2 dispõe os nomes comuns, os nomes científicos e os seus respectivos códigos internacionais da "Weed Science Society of America" (WSSA). Num trabalho onde se considera a ocorrência de plantas daninhas é importante a caracterização das espécies presentes. Estas mesmas espécies foram utilizadas para a realização do estudo de correlação da variabilidade espacial dos mapas de plantas daninhas com os mapas dos atributos da fertilidade do solo. A utilização do código internacional WSSA permite a identificação de cada espécie por uma sigla composta por cinco letras, facilitando a execução do mapeamento de plantas daninhas quando há o envolvimento de muitas espécies, principalmente quando há o envolvimento de espécies de plantas daninhas do mesmo gênero na classificação botânica.

\begin{tabular}{|lcc|}
\hline \multicolumn{1}{|c}{ Nome comum } & Nome científico & Código Internacional WSSA \\
\hline Buva & Conyza bonariensis & ERIBO \\
Capim amargoso & Digitaria insularis & DIGIN \\
Capim carrapicho & Cenchrus echinatus & CCHEC \\
Leiteiro & Ephorbia heterophylla & EPHHL \\
Macelinha & Gnaphalium spicatum & GNASP \\
Picão preto & Bidens pilosa & BIDPI \\
\hline
\end{tabular}

Quadro 2 - Nome comum, nome científico e código internacional WSSA ("Weed Science Society of America") das espécies de plantas daninhas mapeadas pelos métodos de mapeamento por amostragens sistemáticas e pelo contorno das áreas de ocorrência (Lorenzi, 1994).

\subsubsection{Análise estatística dos dados amostrados}

A análise estatística permitiu a verificação da normalidade dos dados e a identificação dos dados discrepantes (“outliers"). Os limites superior e inferior da série de dados amostrados para a identificação dos dados discrepantes foram obtidos pela solução das equações 3 e 4, respectivamente. Após a análise destes dados verificou-se que a remoção dos dados discrepantes proporcionou uma distribuição mais próxima da normal, melhorando significativamente a qualidade da análise geoestatística realizada 
posteriormente. A análise estatística, realizada com o auxílio do software SAS, permitiu obtenção da média, do valor mínimo, do valor máximo, do quartil superior, do quartil inferior, da variância, do desvio padrão, da simetria e da curtose de todas as variáveis mensuradas nos mapeamentos dos atributos da fertilidade do solo e de plantas daninhas pelo método das amostragens (Tabelas 1, 2 e 3).

\subsubsection{Densidade das plantas daninhas}

A Tabela 1 apresenta o resultado da análise estatística descritiva realizada para os dados da variável densidade para as quatro espécies de plantas daninhas mapeadas pelo método das amostragens sistemáticas e que ocorreram em um número maior do que vinte pontos amostrais.

Tabela 1. Resultados da análise estatística descritiva realizada para os dados da variável densidade das plantas daninhas (plantas. $\mathrm{m}^{-2}$ ) para as quatro espécies mapeadas pelo método das amostragens sistemáticas.

\begin{tabular}{lcccc}
\hline & $\begin{array}{c}\text { Capim } \\
\text { carrapicho }\end{array}$ & Leiteiro & Macelinha & Picão preto \\
\hline Média & 8,19 & 6,96 & 9,28 & 5,64 \\
Valor mínimo & 4,00 & 4,00 & 4,00 & 4,00 \\
Valor máximo & 20,00 & 12,00 & 20,00 & 12,00 \\
Quartil superior & 12,00 & 10,00 & 12,00 & 8,00 \\
Quartil inferior & 4,00 & 4,00 & 4,00 & 4,00 \\
Variância & 26,12 & 10,50 & 31,63 & 7,10 \\
Desvio padrão & 5,11 & 3,24 & 5,62 & 2,66 \\
Simetria & 1,23 & 0,53 & 0,94 & 1,43 \\
Curtose & 0,63 & $-1,24$ & $-0,20$ & 0,98 \\
\hline
\end{tabular}

Observa-se que o valor mínimo para todas as variáveis foi igual a 4 plantas. $\mathrm{m}^{-2}$. Isto foi devido a ocorrência de uma planta dentro da área amostral de 0,25 $\mathrm{m}^{2}$. Foram desconsiderados os pontos amostrais onde a espécie de planta daninha não foi observada.

Pode-se verificar também que os valores dos coeficientes de simetria e curtose próximos a 0 sugerem uma distribuição normal para os dados mapeados, não sendo necessária a realização da transformação destes dados (Libardi et al, 1996). Do 
ponto de vista prático, significa que a média aritmética não foi muito afetada por valores extremos após a retirada dos dados discrepantes.

\subsubsection{Estágio de desenvolvimento das plantas daninhas}

A Tabela 2 apresenta o resultado da análise estatística descritiva realizada para os dados da variável estágio de desenvolvimento para as quatro espécies de plantas daninhas mapeadas pelo método das amostragens sistemáticas e que ocorreram em um número maior do que vinte pontos amostrais.

Tabela 2. Resultados da análise estatística descritiva realizada para os dados da variável estágio de desenvolvimento do mapeamento de plantas daninhas pelo método das amostragens sistemáticas.

\begin{tabular}{lcccc}
\hline & $\begin{array}{c}\text { Capim } \\
\text { carrapicho }\end{array}$ & Leiteiro & Macelinha & Picão preto \\
\hline Média & 4,43 & 3,55 & 4,37 & 4,50 \\
Valor mínimo & 1,00 & 1,00 & 2,00 & 2,00 \\
Valor máximo & 6,00 & 6,00 & 5,00 & 6,00 \\
Quartil superior & 6,00 & 4,00 & 5,00 & 6,00 \\
Quartil inferior & 3,00 & 2,00 & 4,00 & 4,00 \\
Variância & 3,14 & 1,83 & 1,17 & 1,46 \\
Desvio padrão & 1,77 & 1,35 & 1,08 & 1,21 \\
Simetria & $-0,66$ & 0,23 & $-1,42$ & $-0,22$ \\
Curtose & $-0,96$ & $-0,26$ & 0,49 & $-0,42$ \\
\hline
\end{tabular}

A transformação da variável discreta estágio de desenvolvimento (3 folhas, 5 folhas, 8 folhas, adulta, flor e fruto) em variável contínua (1, 2, 3, 4, 5 e 6) permitiu a realização das análises estatística e geoestatística. Esta transformação foi necessária pois o processo de interpolação não pode ser aplicado sobre uma variável discreta.

Pode-se observar também na Tabela 2 que os valores dos coeficientes de simetria e curtose próximos a 0 sugerem uma distribuição normal para os dados mapeados.

A Figura 19 mostra a comparação entre as porcentagens dos pontos amostrais onde as espécies de plantas daninhas mapeadas estavam presentes, separadas por estágios de desenvolvimento 


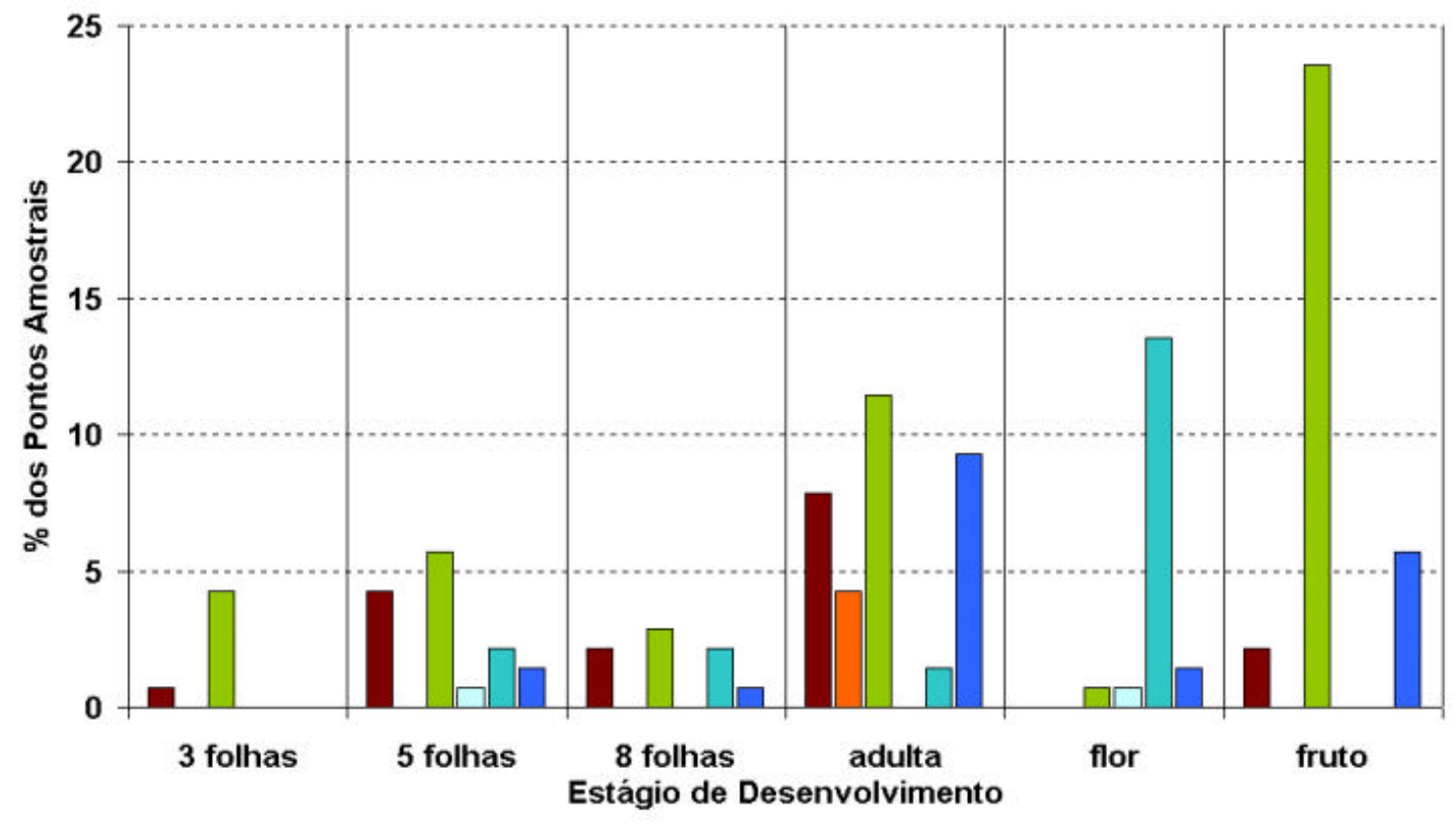

- leiteiro $\square$ buva $\square$ capim carrapicho $\square$ amargoso $\square$ macelinha $\square$ picão preto

Figura 19 - Comparação entre as porcentagens dos pontos amostrais onde as espécies de plantas daninhas mapeadas estavam presentes, separadas por estágios de desenvolvimento.

Uma mesma espécie de planta daninha pode ser observada em diversos estágios de desenvolvimento. Destacam-se as espécies de plantas daninhas macelinha e picão preto, presentes na maioria dos pontos amostrais em estágios avançados de desenvolvimento, como plantas florescendo e plantas frutificando, respectivamente.

\subsubsection{Atributos da fertilidade do solo}

A Tabela 3 mostra os resultados da análise estatística descritiva realizada para as variáveis do mapeamento dos atributos da fertilidade do solo. Pode-se verificar que os dados são muito homogêneos, ou seja, as variáveis do mapeamento de fertilidade do solo possuem pouca variabilidade. Este fato é devido às adubações de manutenção realizadas na área para a implantação das culturas no sistema de cultivo pelo plantio direto. 
Tabela 3. Resultados da análise estatística descritiva realizada para as variáveis do mapeamento dos atributos da fertilidade do solo.

\begin{tabular}{|c|c|c|c|c|c|c|c|c|c|}
\hline & Média & $\begin{array}{c}\text { Valor } \\
\text { mínimo }\end{array}$ & $\begin{array}{c}\text { Valor } \\
\text { máximo }\end{array}$ & $\begin{array}{l}\text { Quartil } \\
\text { superior }\end{array}$ & $\begin{array}{l}\text { Quartil } \\
\text { inferior }\end{array}$ & Variância & $\begin{array}{l}\text { Desvio } \\
\text { padrão }\end{array}$ & Simetria & Curtose \\
\hline $\mathrm{pH}$ & 5,78 & 5,30 & 6,40 & 6,00 & 5,60 & 0,08 & 0,27 & $-0,05$ & $-0,49$ \\
\hline $\mathrm{CTC}^{1}$ & 61,65 & 50,00 & 79,00 & 66,50 & 56,50 & 49,35 & 7,02 & 0,22 & $-0,10$ \\
\hline $\mathrm{V}^{2}$ & 75,44 & 64,00 & 86,00 & 79,00 & 72,00 & 28,41 & 5,33 & $-0,47$ & $-0,05$ \\
\hline $\mathrm{MO}^{3}$ & 15,48 & 12,00 & 19,00 & 17,00 & 14,00 & 3,33 & 1,83 & 0,07 & $-1,07$ \\
\hline $\mathrm{P}^{4}$ & 29,15 & 11,00 & 71,00 & 43,00 & 21,50 & 147,28 & 12,14 & 1,20 & 2,83 \\
\hline $\mathrm{K}^{1}$ & 1,08 & 0,40 & 2,10 & 1,40 & 0,80 & 0,16 & 0,39 & 0,46 & 0,32 \\
\hline $\mathrm{Ca}^{1}$ & 31,18 & 20,00 & 43,00 & 35,00 & 27,50 & 29,10 & 5,39 & 0,33 & $-0,26$ \\
\hline $\mathrm{Mg}^{1}$ & 14,53 & 8,00 & 21,00 & 17,00 & 13,00 & 9,91 & 3,15 & $-0,08$ & $-0,16$ \\
\hline $\mathrm{S}^{4}$ & 3,20 & 1,00 & 6,00 & 4,50 & 2,00 & 2,10 & 1,45 & 0,21 & $-0,94$ \\
\hline $\mathrm{Fe}^{4}$ & 23,89 & 17,00 & 34,00 & 28,00 & 20,00 & 22,69 & 4,76 & 0,22 & $-0,82$ \\
\hline $\mathrm{Cu}^{4}$ & 0,76 & 0,70 & 0,80 & 0,80 & 0,70 & 0,00 & 0,05 & $-0,25$ & $-2,06$ \\
\hline $\mathrm{Mn}^{4}$ & 1,61 & 1,00 & 2,40 & 2,00 & 1,20 & 0,18 & 0,43 & 0,03 & $-1,17$ \\
\hline $\mathrm{Zn}^{4}$ & 0,64 & 0,30 & 1,70 & 4,00 & 0,85 & 0,10 & 0,31 & 1,42 & 2,48 \\
\hline $\mathrm{B}^{4}$ & 0,09 & 0,05 & 0,17 & 0,13 & 0,06 & 0,00 & 0,04 & 0,43 & $-1,22$ \\
\hline
\end{tabular}

Pode-se observar também na Tabela 3 que os valores dos coeficientes de simetria e curtose estão próximos a 0 , sugerindo que a distribuição dos dados é próxima a normal.

\subsubsection{Análise geoestatística dos dados amostrados}

Dentre as etapas para a obtenção dos mapas, a análise geoestatística foi a que mais exigiu tempo na busca do melhor modelo de semivariograma teórico, culminando na geração do mapa mais fiel à realidade da variabilidade espacial do atributo mapeado pelo processo de interpolação por krigagem.

\subsubsection{Densidade das plantas daninhas}

A Tabela 4 lustra o resultado da análise geoestatística para os dados da variável densidade do mapeamento de plantas daninhas efetuado pelo método das amostragens sistemáticas. Estão listados todos os parâmetros que foram utilizados para seleção do melhor modelo do semivariograma e para a interpolação por krigagem 
Tabela 4. Resultados da análise geoestatística para os dados da variável densidade (plantas. $\mathrm{m}^{-2}$ ) para as quatro espécies de plantas daninhas mapeadas pelo método das amostragens sistemáticas.

\begin{tabular}{lcccccc}
\hline & Modelo & $\mathrm{Co}^{1}$ & $\mathrm{Co}+\mathrm{C}^{2}$ & $\mathrm{~A}(\mathrm{~m})^{3}$ & $\begin{array}{c}\mathrm{Co} / \mathrm{Co}+\mathrm{C} \\
(\%)\end{array}$ & $\mathrm{r}^{2}(\%)$ \\
\hline Capim carrapicho & Esférico & 9,000 & 67,090 & 32,4 & 13,4 & 46 \\
Leiteiro & Esférico & 0,010 & 13,530 & 173,3 & 0,1 & 96 \\
Macelinha & Esférico & 0,900 & 52,900 & 68,5 & 1,7 & 35 \\
Picão preto & Esférico & 0,100 & 34,240 & 83,8 & 0,3 & 99 \\
\hline
\end{tabular}

${ }^{1}$ efeito pepita; ${ }^{2}$ patamar; ${ }^{3}$ alcance

O parâmetro $\mathrm{r}^{2}$ ilustra o coeficiente de correlação obtido pela validação cruzada. Quanto maior o $\mathrm{r}^{2}$, melhor o modelo encontrado descreve a variabilidade espacial da espécie mapeada.

O grau de dependência espacial dos semivariogramas ajustados foi considerado forte para todas as plantas daninhas mapeadas.

Os modelos do semivariogramas com efeito pepita pequeno (leiteiro, macelinha e picão preto) mostram que toda a variabilidade espacial está sendo descrita adequadamente pelo modelo ajustado.

Pode-se observar que houve uma variação no alcance dos semivariogramas ajustados entre 32,4 a $173,3 \mathrm{~m}$, mostrando que a distância interamostral utilizada para o mapeamento da densidade das espécies de plantas daninhas foi adequada $(25 \mathrm{~m})$.

$\mathrm{O}$ modelo que se mostrou mais adequado para explicar a estrutura da variabilidade espacial da densidade de ocorrência das espécies de plantas daninhas mapeadas foi o esférico.

\subsubsection{Estágio de desenvolvimento das plantas daninhas}

A Tabela 5 ilustra o resultado da análise geoestatística realizada para os dados da variável estágio de desenvolvimento das plantas daninhas mapeadas pelo método das amostragens sistemáticas 
Tabela 5. Resultados da análise geoestatística realizada para os dados da variável estágio de desenvolvimento do mapeamento de plantas daninhas pelo método das amostragens sistemáticas.

\begin{tabular}{lcccccc}
\hline & Modelo & $\mathrm{Co}^{1}$ & $\mathrm{Co}+\mathrm{C}^{2}$ & $\mathrm{~A}(\mathrm{~m})^{3}$ & $\begin{array}{c}\mathrm{Co} / \mathrm{Co}+\mathrm{C} \\
(\%)\end{array}$ & $\mathrm{r}^{2}(\%)$ \\
\hline Capim carrapicho & Esférico & 0,001 & 2,630 & 48,3 & 0,0 & 85 \\
Leiteiro & Esférico & 0,001 & 1,371 & 36,0 & 0,1 & 30 \\
Macelinha & Exponencial & 0,230 & 2,310 & 413,0 & 10,0 & 78 \\
Picão preto & Esférico & 0,001 & 2,084 & 56,4 & 0,0 & 40 \\
\hline
\end{tabular}

${ }^{1}$ efeito pepita; ${ }^{2}$ patamar ${ }^{3}$ alcance

O grau de dependência espacial dos semivariogramas ajustados para o atributo estágio de desenvolvimento das plantas daninhas foi considerado forte.

Pode-se observar que houve uma variação no alcance dos semivariogramas ajustados entre 48,3 a 413,0 m, mostrando também que a distância interamostral utilizada para o mapeamento do estágio de desenvolvimento das espécies de plantas daninhas foi adequada $(25 \mathrm{~m})$. Verifica-se que o alcance do modelo ajustado para a macelinha foi elevado, porém, verifica-se também que este modelo foi bem ajustado, ilustrado pelo $\mathrm{r}^{2}$.

$\mathrm{O}$ modelo que se mostrou mais adequado para explicar a estrutura da variabilidade espacial do estágio de desenvolvimento das espécies de plantas daninhas mapeadas foi o esférico, exceto para a macelinha, que foi o exponencial.

\subsubsection{Atributos da fertilidade do solo}

A Tabela 6 mostra os resultados da análise geoestatística para as variáveis do mapeamento dos atributos da fertilidade do solo. 
Tabela 6. Resultados da análise geoestatística para as variáveis do mapeamento dos atributos da fertilidade do solo.

\begin{tabular}{lcccccc}
\hline & Modelo & $\mathrm{Co}^{1}$ & $\mathrm{Co}+\mathrm{C}^{2}$ & $\mathrm{~A}(\mathrm{~m})^{3}$ & $\begin{array}{c}\mathrm{Co} / \mathrm{Co}+\mathrm{C} \\
(\%)\end{array}$ & $\mathrm{r}^{2}(\%)$ \\
\hline $\mathrm{PH}$ & Esférico & 0,017 & 0,076 & 145,0 & 22,8 & 30 \\
$\mathrm{CTC}$ & Esférico & 33,300 & 76,760 & 281,0 & 43,4 & 68 \\
$\mathrm{~V}$ & Esférico & 0,010 & 11,700 & 104,0 & 0,1 & 25 \\
$\mathrm{MO}$ & Esférico & 1,150 & 4,566 & 529,0 & 25,2 & 90 \\
$\mathrm{P}$ & Esférico & 130,000 & 680,200 & 91,0 & 19,1 & 60 \\
$\mathrm{~K}$ & Exponencial & 0,163 & 0,328 & 453,5 & 49,8 & 58 \\
$\mathrm{Ca}$ & Exponencial & 21,780 & 43,570 & 188,0 & 50,0 & 30 \\
$\mathrm{Mg}$ & Esférico & 5,910 & 12,170 & 266,0 & 48,6 & 76 \\
$\mathrm{~S}$ & Exponencial & 1,460 & 2,921 & 293,3 & 50,0 & 71 \\
$\mathrm{Fé}$ & Esférico & 5,220 & 33,130 & 41,9 & 15,8 & 51 \\
$\mathrm{Cu}$ & Exponencial & 0,002 & 0,004 & 126,0 & 47,5 & 85 \\
$\mathrm{Mn}$ & Esférico & 0,051 & 0,201 & 288,1 & 25,6 & 94 \\
$\mathrm{Zn}$ & Esférico & 0,000 & 0,115 & 91,4 & 0,1 & 28 \\
$\mathrm{~B}$ & Esférico & 0,001 & 0,002 & 210,4 & 50,0 & 90 \\
\hline iefeito pepita; ${ }^{2}$ patamar; ${ }^{3}$ alcance & & & & &
\end{tabular}

$\mathrm{O}$ grau de dependência espacial do semivariograma dos atributos $\mathrm{pH}, \mathrm{V} \%$, MO, P, Fe, Mn e Zn foi considerado forte. Para os outros atributos (CTC, K, Ca, Mg, S, $\mathrm{Cu}$ e B) este grau de dependência espacial foi considerado moderado.

Pode-se observar também na Tabela 6 que os alcances dos semivariogramas ajustados mostram que a distância interamostral utilizada para o mapeamento dos atributos da fertilidade do solo foi adequada $(50 \mathrm{~m})$ para as condições da área experimental, com exceção ao Fe, cujo modelo de semivariograma ajustado apresentou alcance de 41, $9 \mathrm{~m}$. Vale ressaltar que a grade amostral para o mapeamento dos atributos da fertilidade do solo foi de 50 x $50 \mathrm{~m}$, porém, como ilustra a Figura 15, a análise geoestatística englobou variações existentes numa escala maior, pois foram dispostos pontos amostrais intencionalmente com distâncias interamostrais menores do que a da grade amostral.

Os modelos que se mostraram mais adequados para explicar a estrutura da variabilidade espacial dos atributos da fertilidade do solo mapeados foram o esférico e o exponencial. 


\subsection{Mapas de plantas daninhas e dos atributos da fertilidade do solo}

\subsubsection{Mapas de plantas daninhas obtidos pela metodologia das amostragens sistemáticas}

Obtidos os parâmetros dos semivariogramas dos atributos mapeados pela análise geoestatística realizourse a elaboração dos mapas de plantas daninhas pelo método de interpolação por krigagem das seguintes espécies de plantas daninhas: capim carrapicho, leiteiro, macelinha e picão preto. Também foram obtidos os mapas de plantas daninhas pelo método do inverso do quadrado da distância das espécies que ocorreram num menor número de pontos amostrais: buva e capim amargoso. Como já descrito no item 4.2, somente foi possível a elaboração dos mapas de plantas daninhas, por algum método de interpolação (krigagem ou inverso do quadrado da distância), destas seis espécies. Porém, pelo método de mapeamento de plantas daninhas por amostragens sistemáticas, quatorze espécies ocorreram em pelo menos um dos pontos da grade amostral, sendo que oito espécies ocorreram em somente um ou dois pontos amostrais, não sendo possível a obtenção do mapa ilustrativo de sua distribuição espacial por algum método de interpolação. Estas oito espécies de plantas daninhas mapeadas foram: beiço-de-boi (Desmodium tortuosum), beldroega (Portulaca oleracea), gizo-decascavel (Crotalaria incana), nabiça (Raphanus raphanistrum), poaia-branca (Richardia brasiliensis), trapoeraba (Commelina benghalensis), capim-oferecido (Pennisetum setosum) e caruru (Amaranthus deflexus).

As Figuras 20 a 31 ilustram a variabilidade espacial dos mapas interpolados do estágio de desenvolvimento e da densidade das espécies de plantas daninhas mapeadas. 


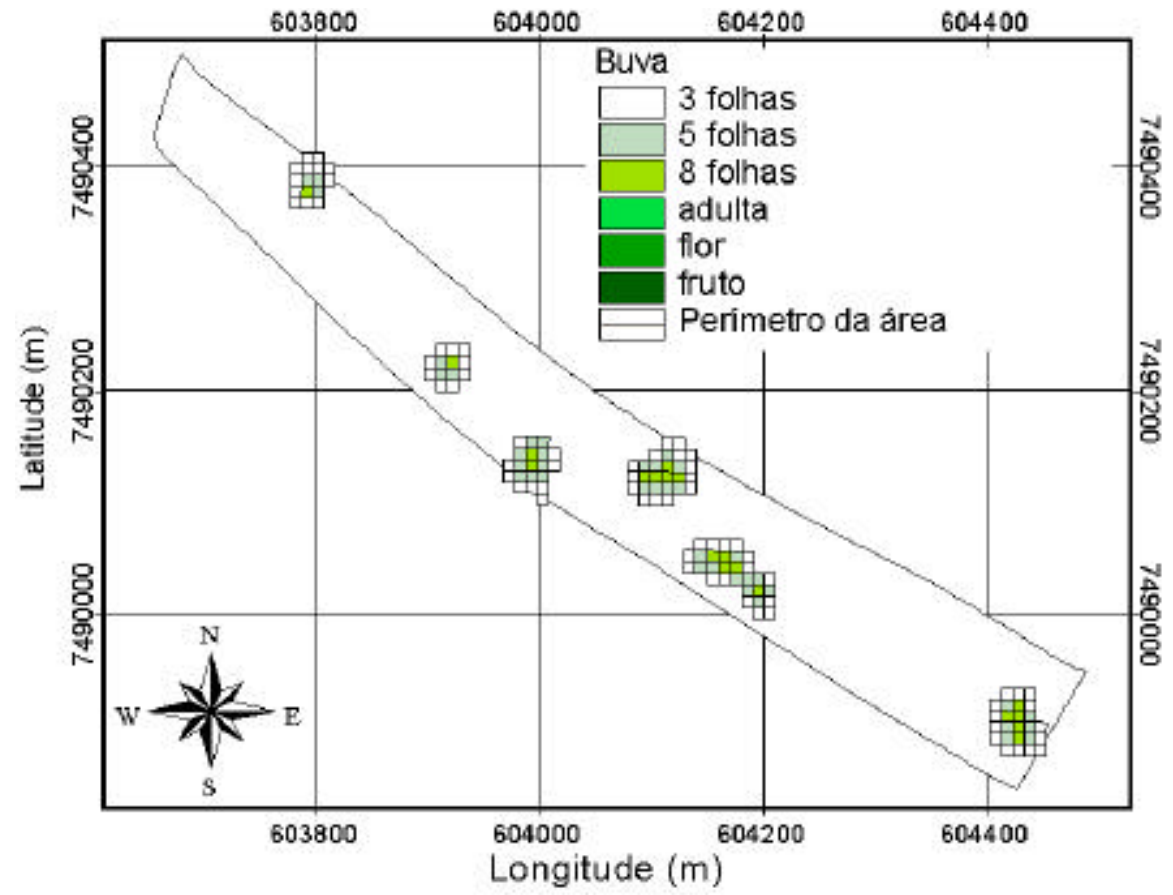

Figura 20 - Ilustração da variabilidade espacial do estágio de desenvolvimento da planta daninha buva.

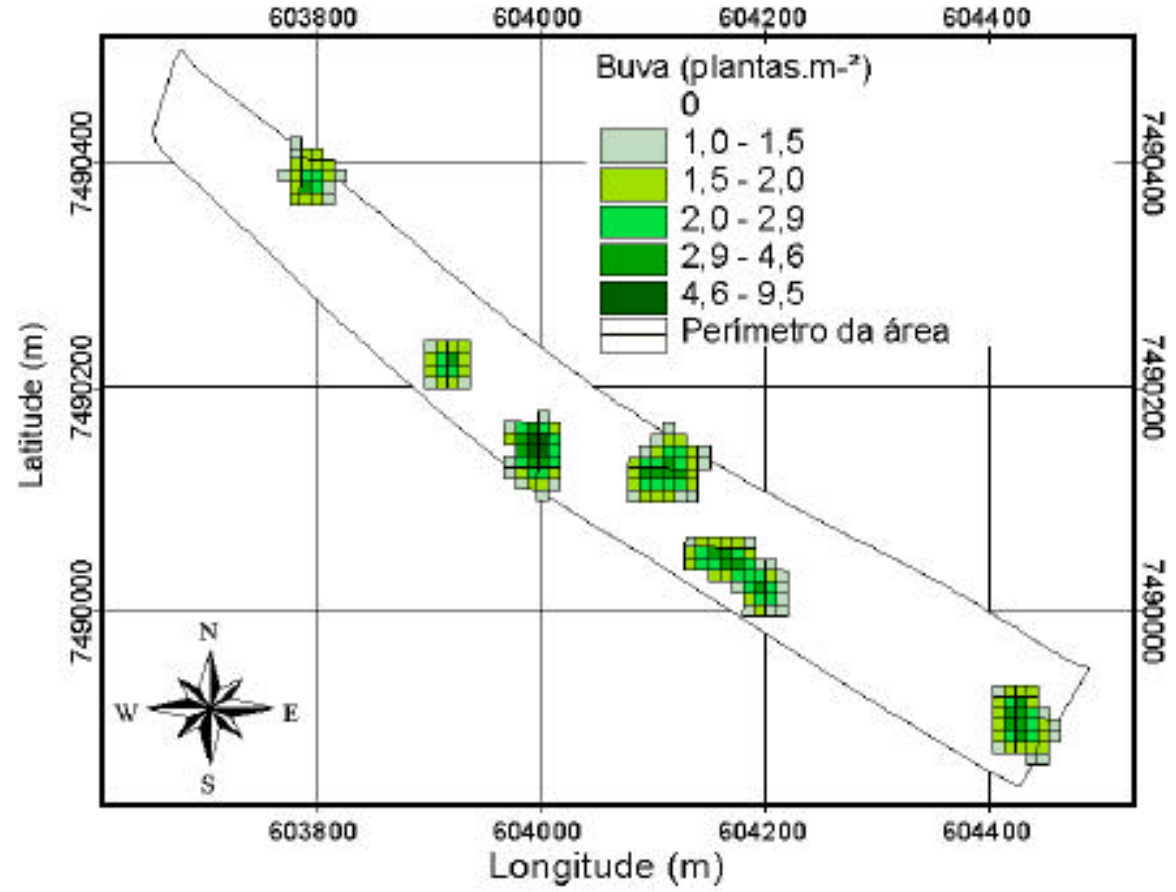

Figura 21 - Ilustração da variabilidade espacial da densidade (plantas.m²) de ocorrência da planta daninha buva. 


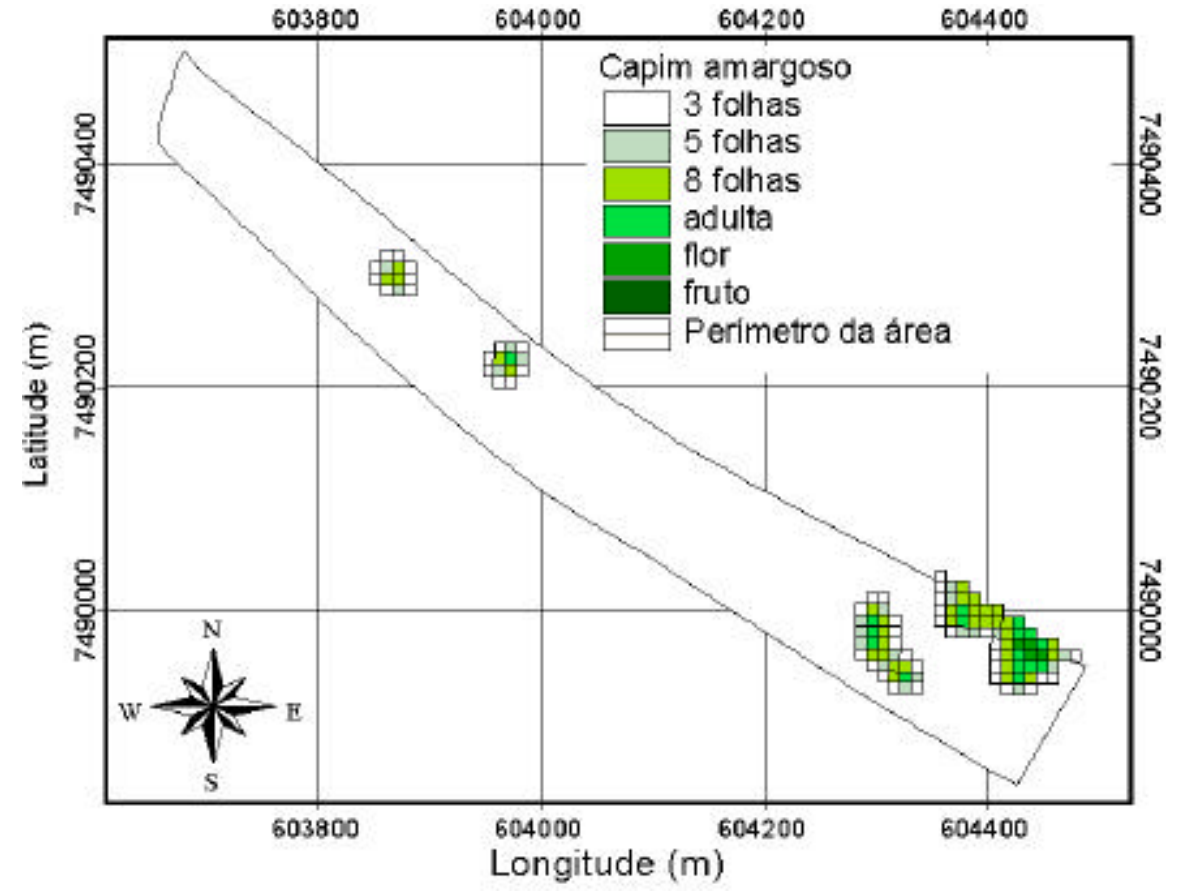

Figura 22 - Ilustração da variabilidade espacial do estágio de desenvolvimento da planta daninha capim amargoso.

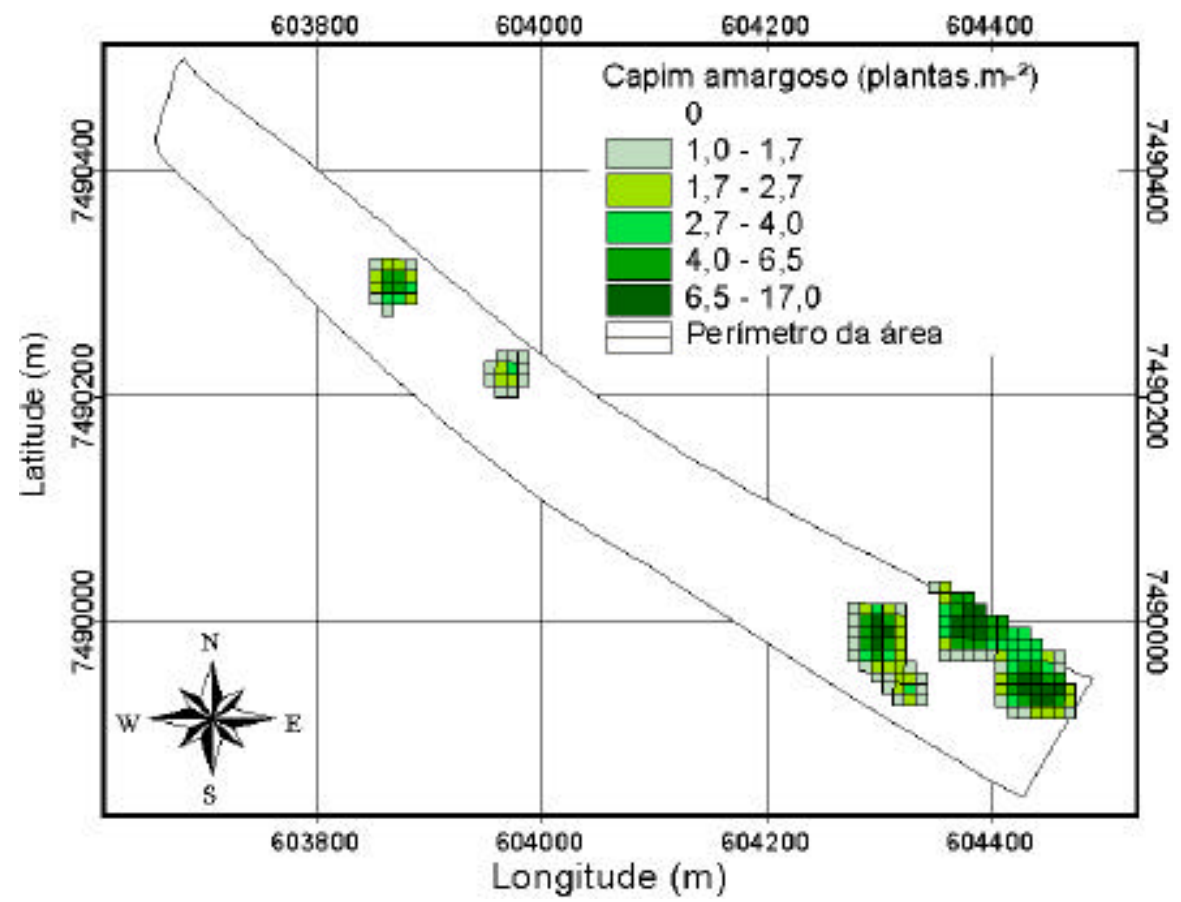

Figura 23 - Ilustração da variabilidade espacial da densidade (plantas.m²) de ocorrência da planta daninha capim amargoso. 


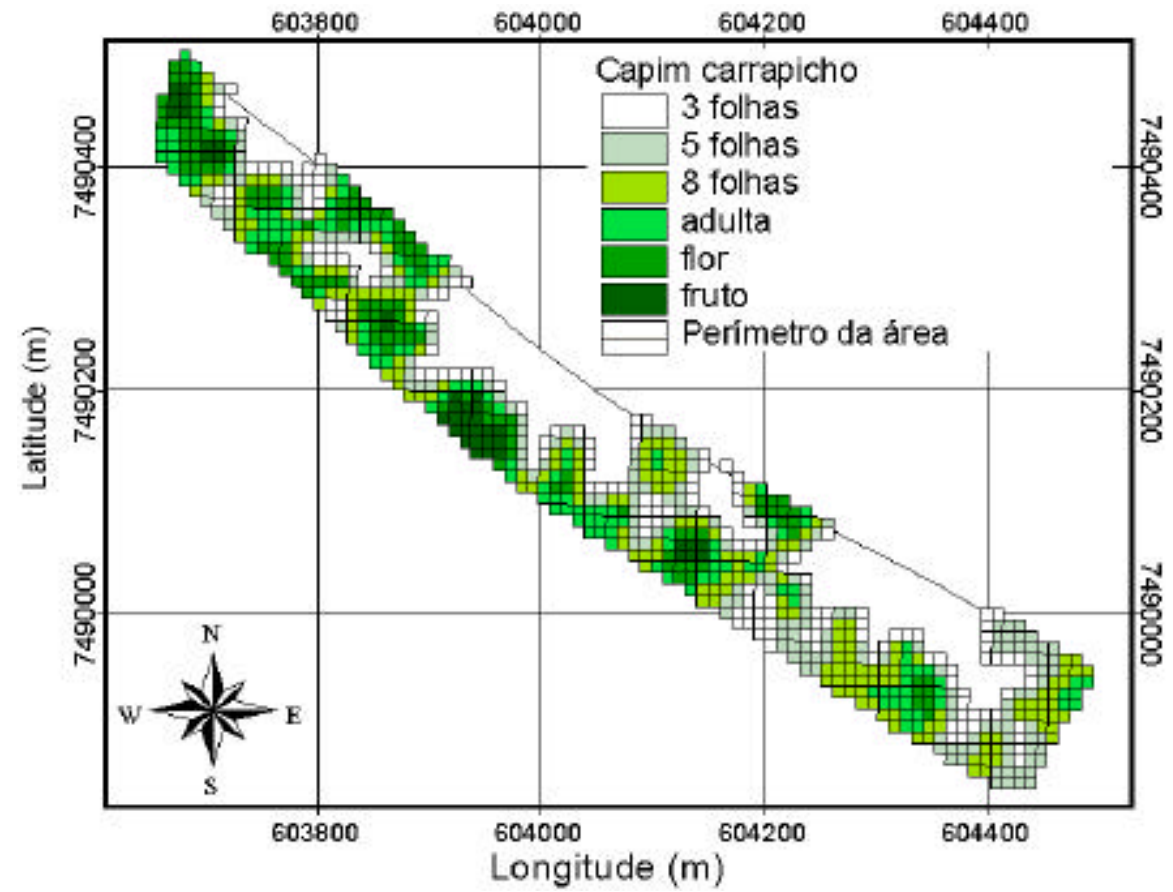

Figura 24 - Ilustração da variabilidade espacial do estágio de desenvolvimento da planta daninha capim carrapicho.

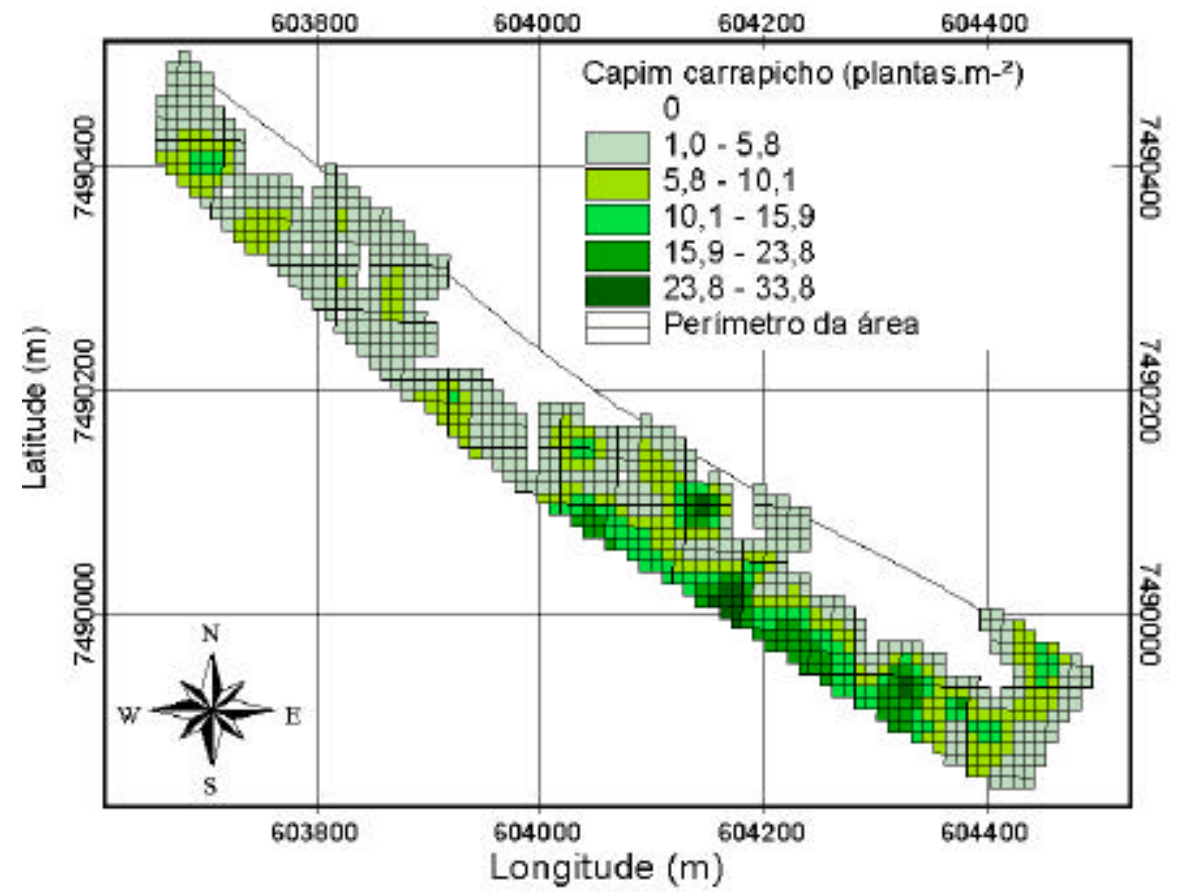

Figura 25 - Ilustração da variabilidade espacial da densidade (plantas.m $m^{-2}$ ) de ocorrência da planta daninha capim carrapicho. 


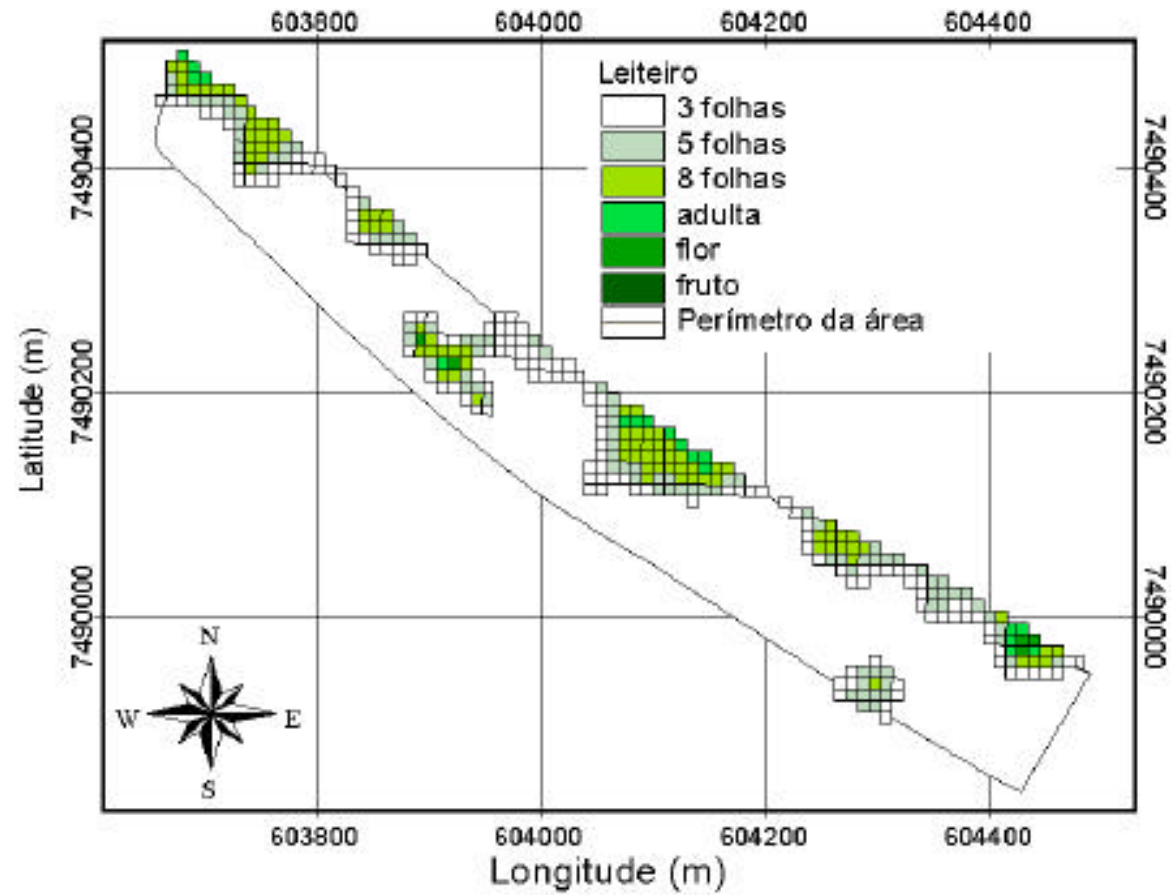

Figura 26 - Ilustração da variabilidade espacial do estágio de desenvolvimento da planta daninha leiteiro.

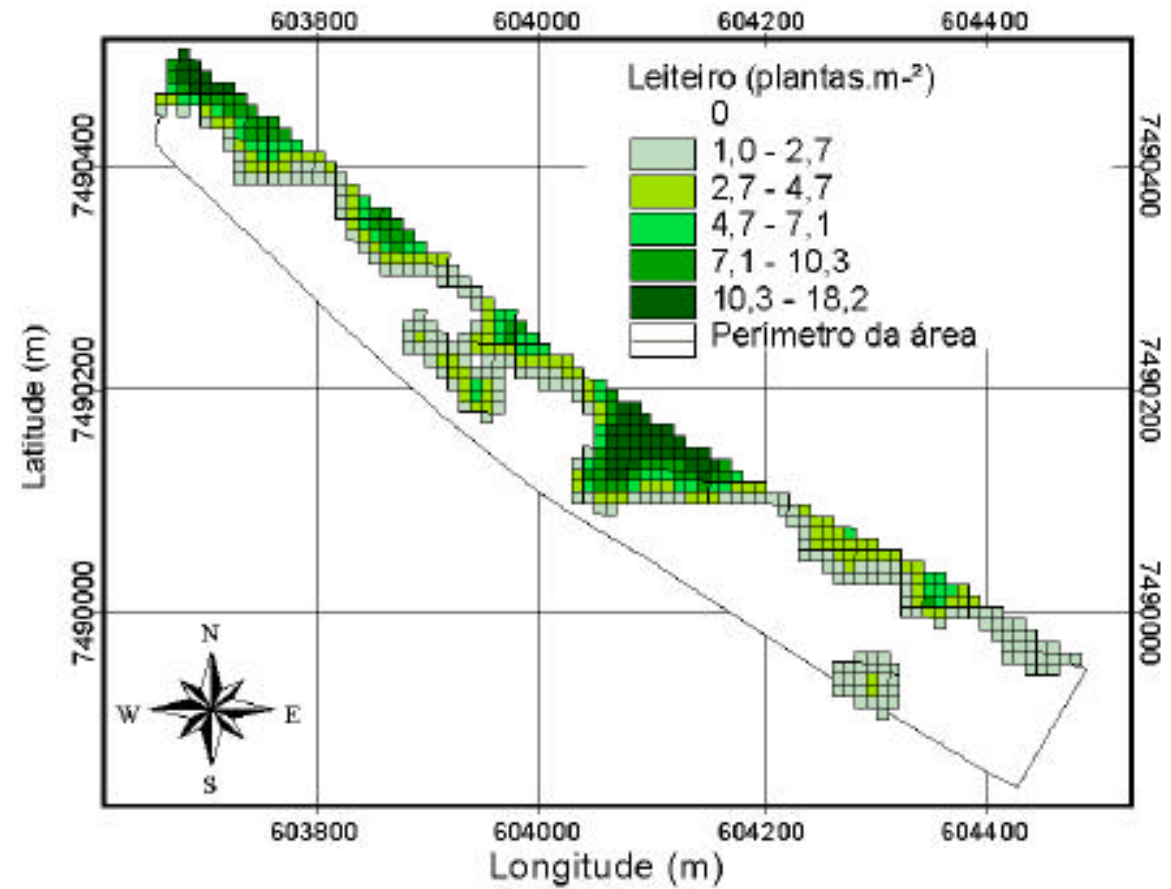

Figura 27 - Ilustração da variabilidade espacial da densidade (plantas.m²) de ocorrência da planta daninha leiteiro. 


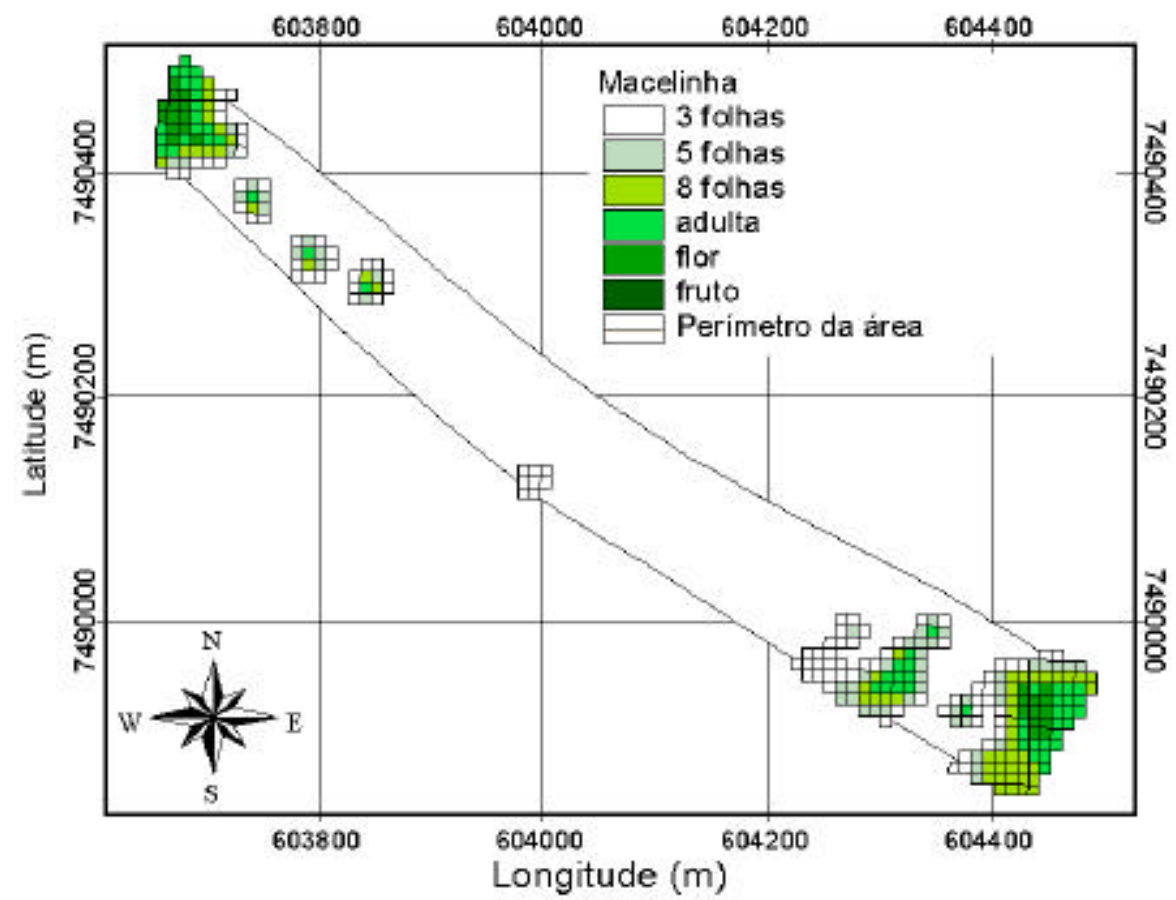

Figura 28 - Ilustração da variabilidade espacial do estágio de desenvolvimento da planta daninha macelinha.

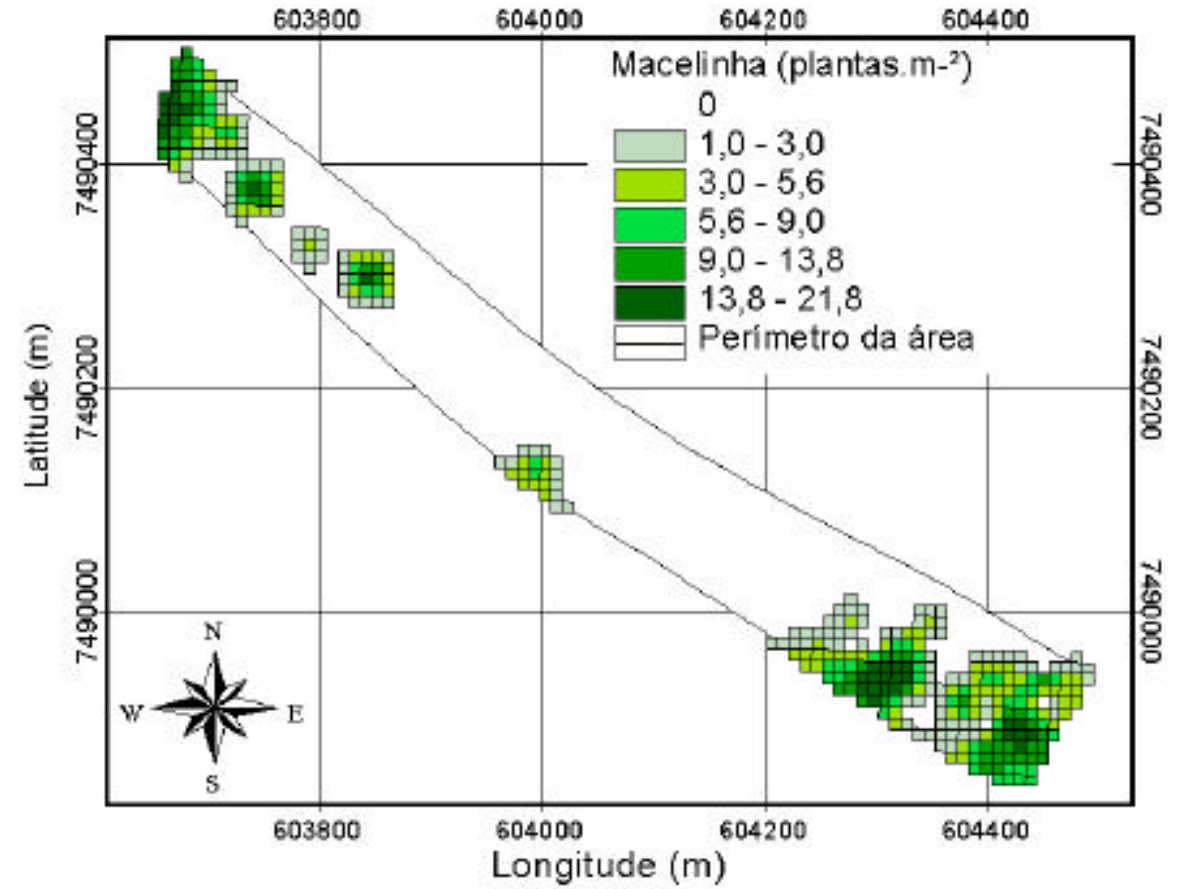

Figura 29 - Ilustração da variabilidade espacial da densidade (plantas.m²) de ocorrência da planta daninha macelinha. 


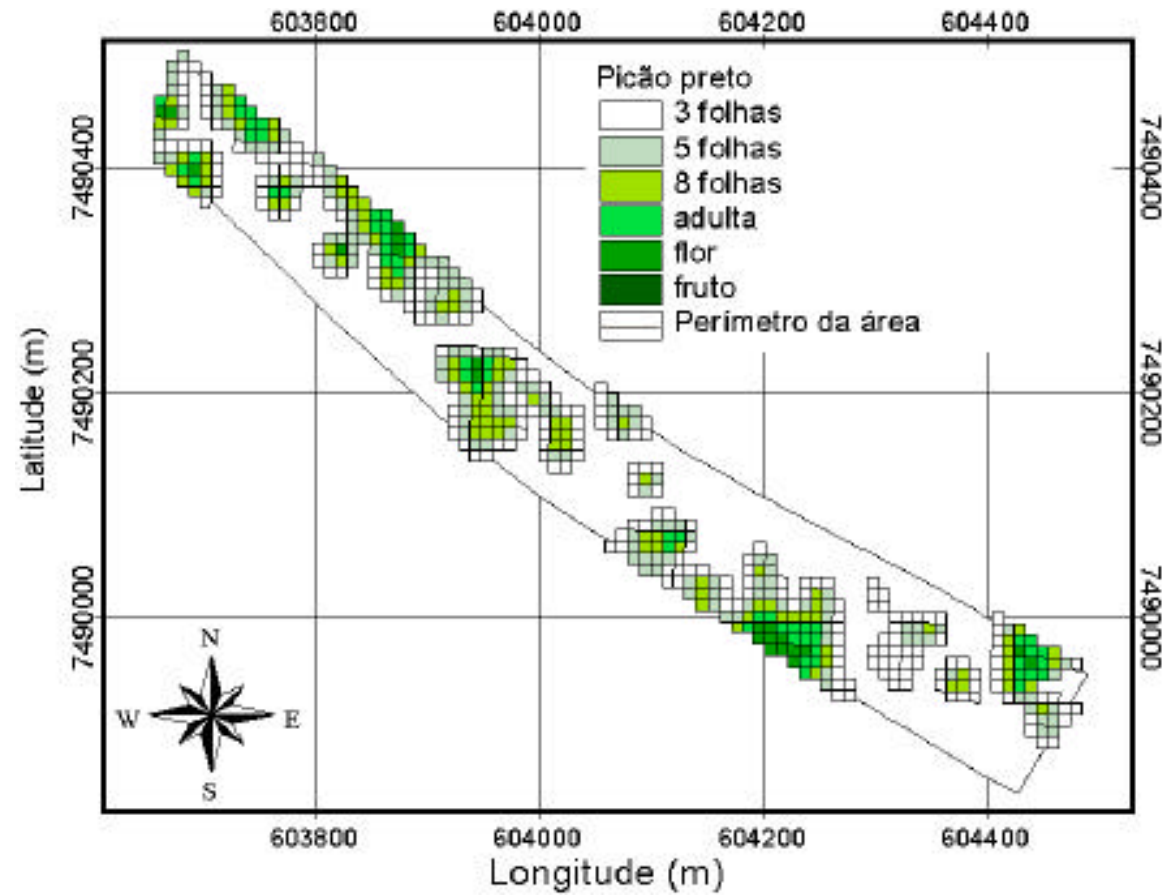

Figura 30 - Ilustração da variabilidade espacial do estágio de desenvolvimento da planta daninha picão preto.

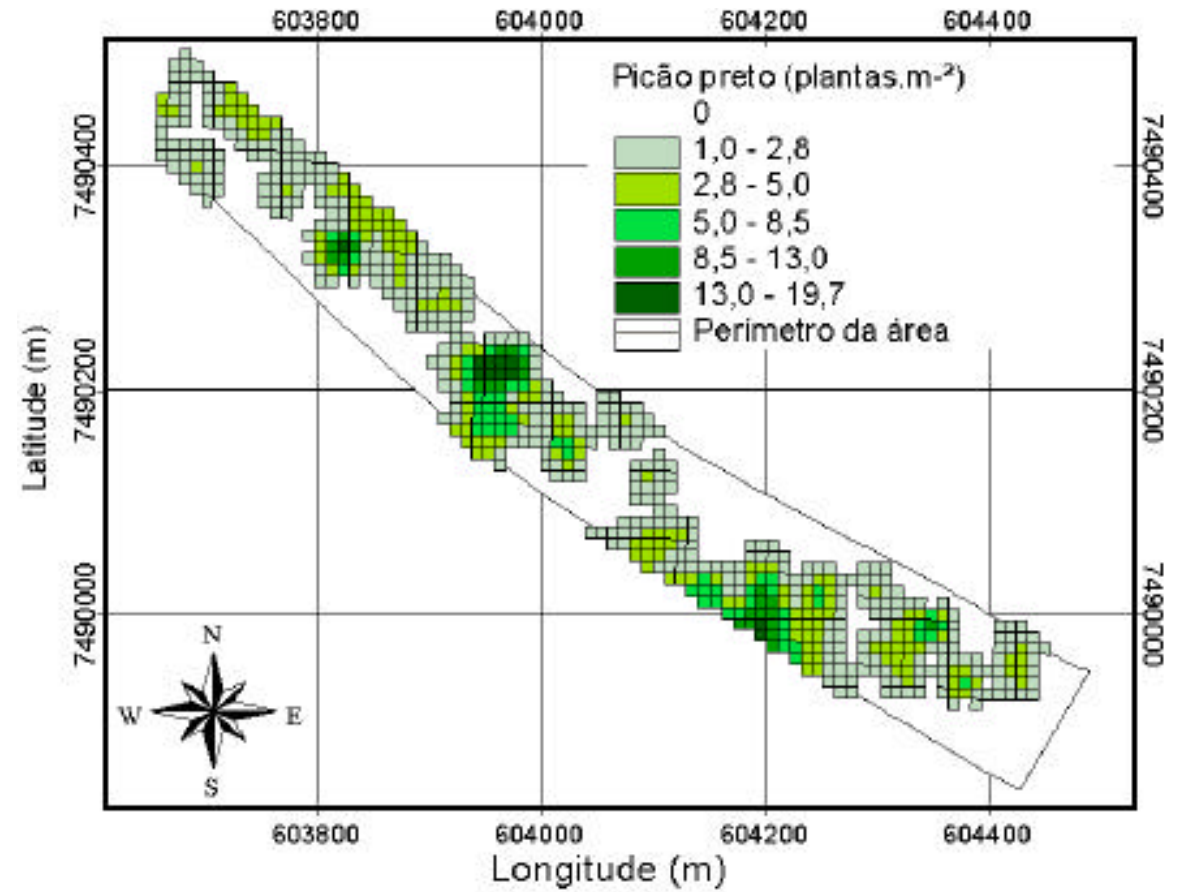

Figura 31 - Ilustração da variabilidade espacial da densidade (plantas.m²) de ocorrência da planta daninha picão preto. 
Pode-se observar, principalmente nas Figuras 24 e 25, que nem sempre o local onde houve a maior densidade de uma espécie de planta daninha houve a ocorrência desta espécie num maior estágio de desenvolvimento. Ou seja, a variabilidade espacial de um atributo mapeado não seguiu a mesma variabilidade espacial do outro atributo. Este fato mostra que realizar a variação da dosagem do herbicida em função da variabilidade espacial da densidade das plantas daninhas não é coerente, pois a dosagem do herbicida é definida em função da espécie e de seu estágio de desenvolvimento e não em função da densidade de ocorrência da espécie (Rodrigues \& Almeida, 1998).

Desta forma, num mapeamento de plantas daninhas deve-se dar prioridade ao levantamento das informações das espécies presentes e seus respectivos estágios de desenvolvimento, dando menor importância a densidades de ocorrência da espécie.

Por esta metodologia de mapeamento das plantas daninhas, o trabalho do levantamento dos dados em campo foi realizado em quatorze horas.

\subsubsection{Mapas de plantas daninhas obtidos pela metodologia do contorno das manchas de ocorrência}

Foi verificado numa análise preliminar ao mapeamento de plantas daninhas que as espécies somente poderiam ser mapeadas em dois níveis de infestação: baixa e alta infestação. Foram consideradas manchas de plantas daninhas com alta infestação aquelas que possibilitaram a identificação visual da área onde a espécie mapeada ocorria num maior nível de agregação.

As Figuras 32 a 37 ilustram os mapas obtidos pela metodologia de mapeamento de plantas daninhas pelo contorno das manchas de ocorrência. 


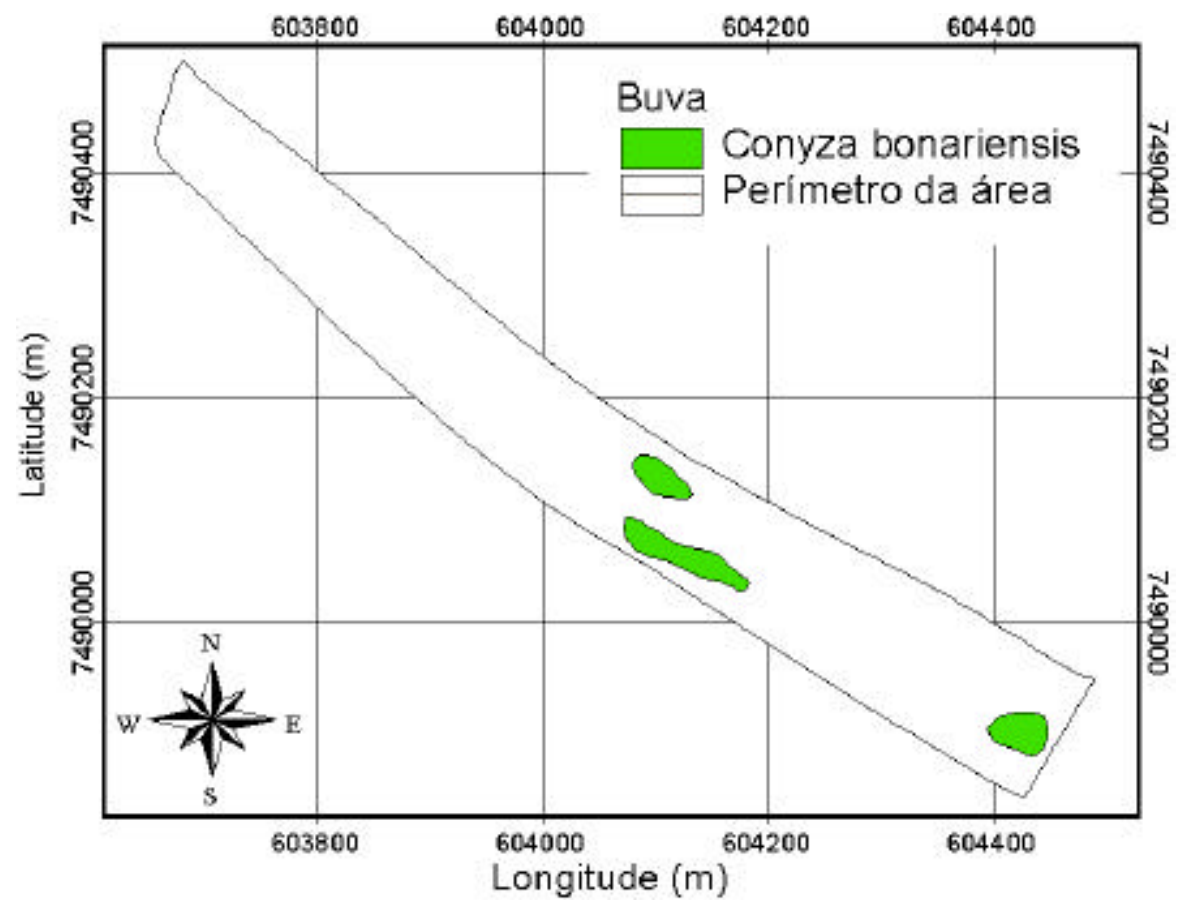

Figura 32 - Ilustração da variabilidade espacial da planta daninha buva mapeada pela metodologia do contorno das manchas de ocorrência.

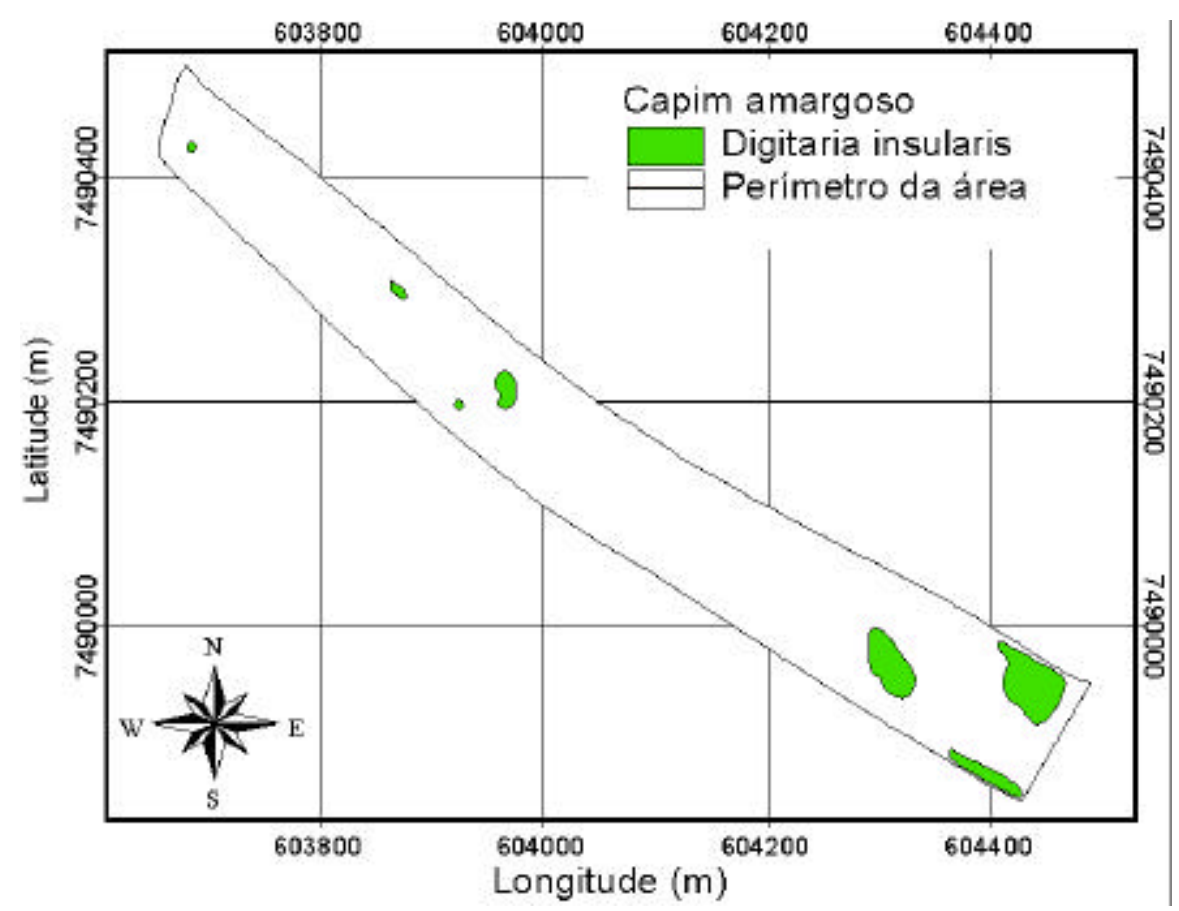

Figura 33 - Ilustração da variabilidade espacial da planta daninha capim amargoso mapeada pela metodologia do contorno das manchas de ocorrência. 


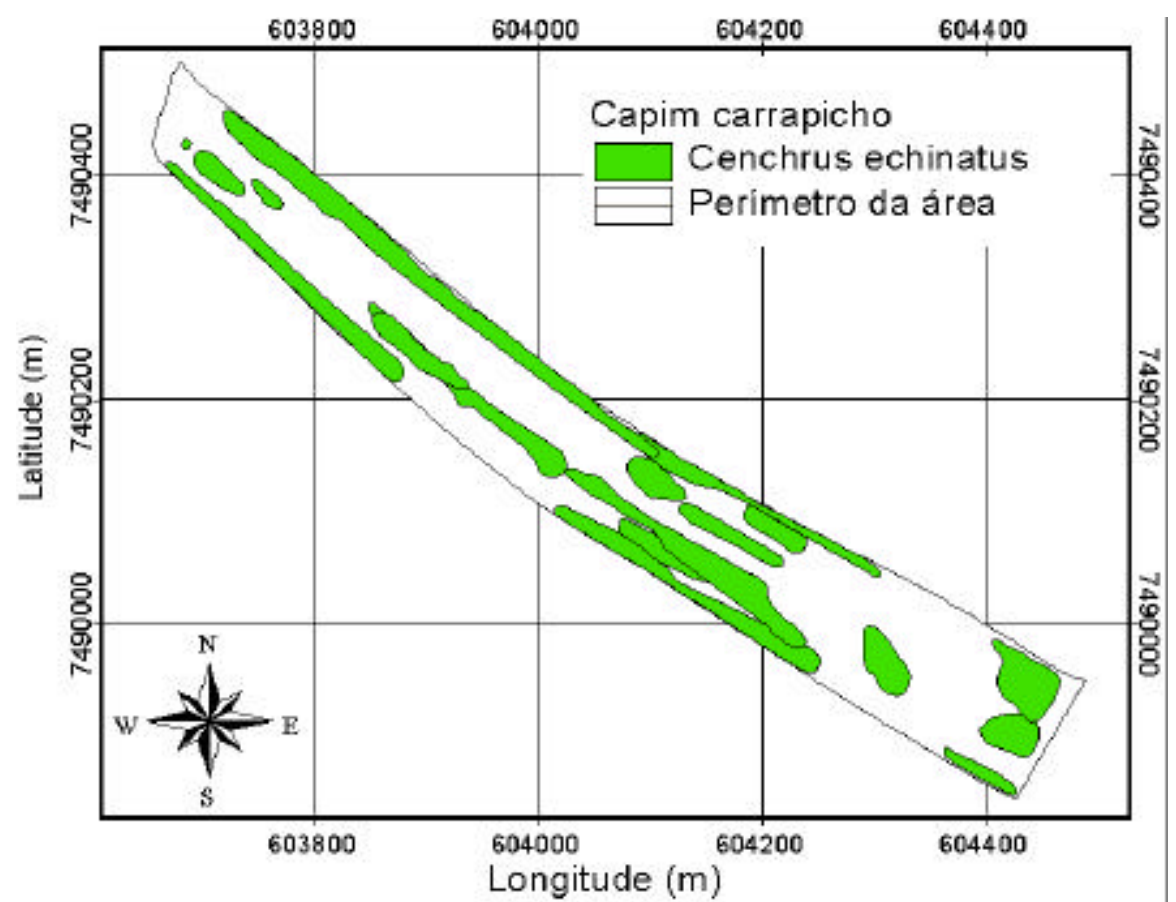

Figura 34 - Ilustração da variabilidade espacial da planta daninha capim carrapicho mapeada pela metodologia do contorno das manchas de ocorrência.

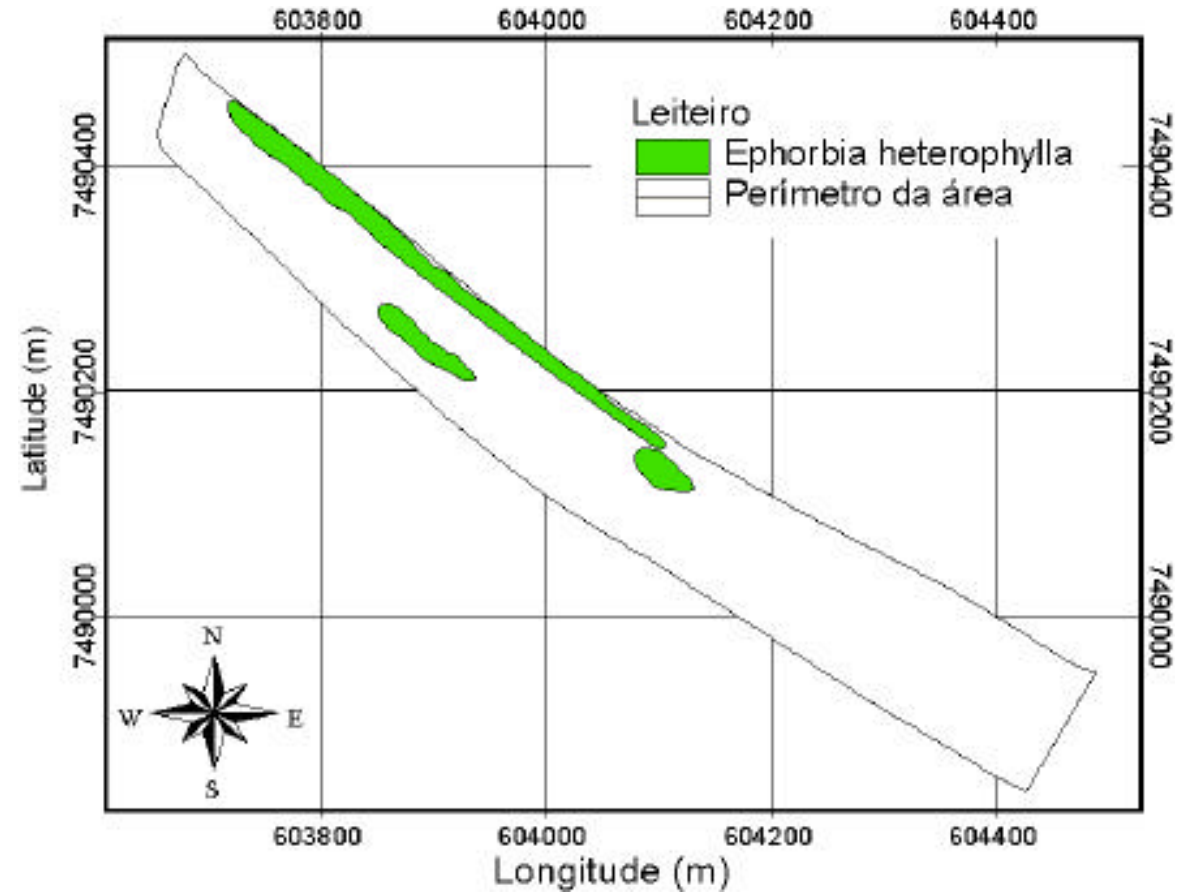

Figura 35 - Ilustração da variabilidade espacial da planta daninha leiteiro mapeada pela metodologia do contorno das manchas de ocorrência. 


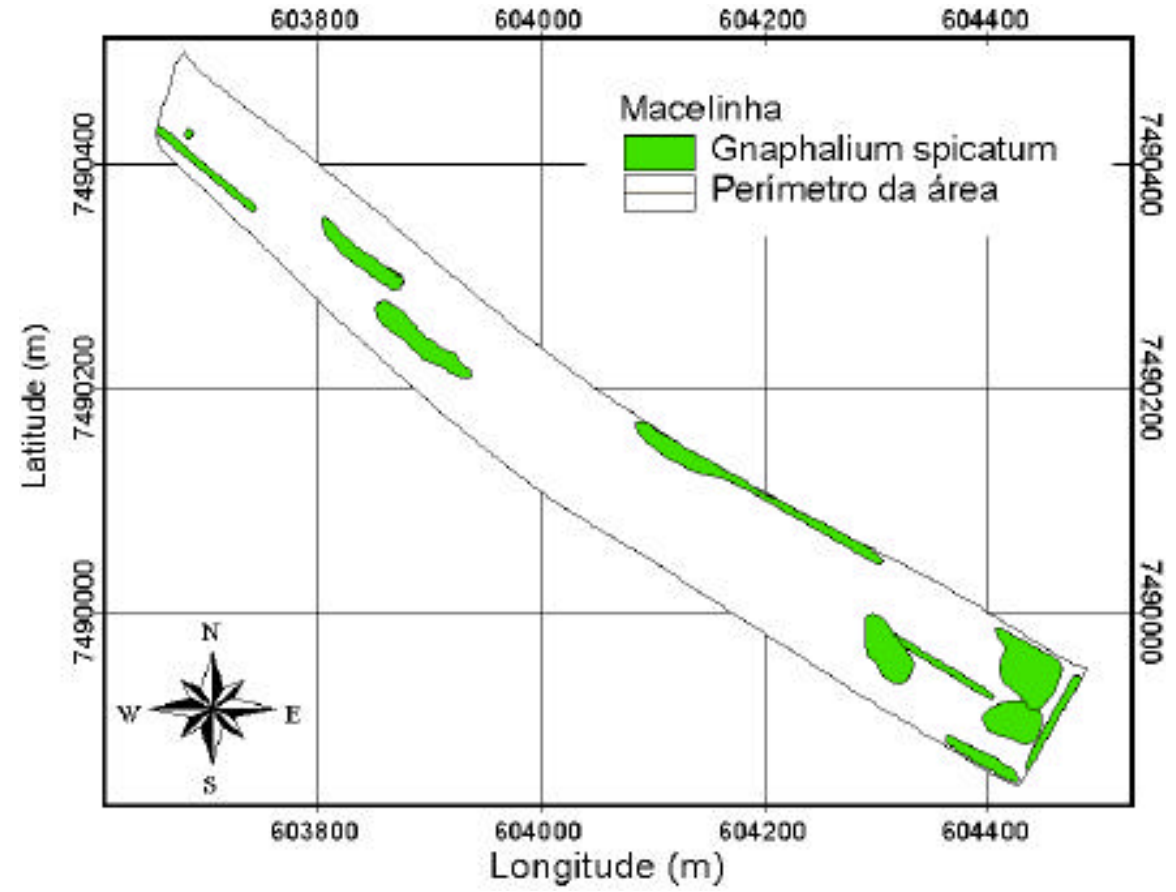

Figura 36 - Ilustração da variabilidade espacial da planta daninha macelinha mapeada pela metodologia do contorno das manchas de ocorrência.

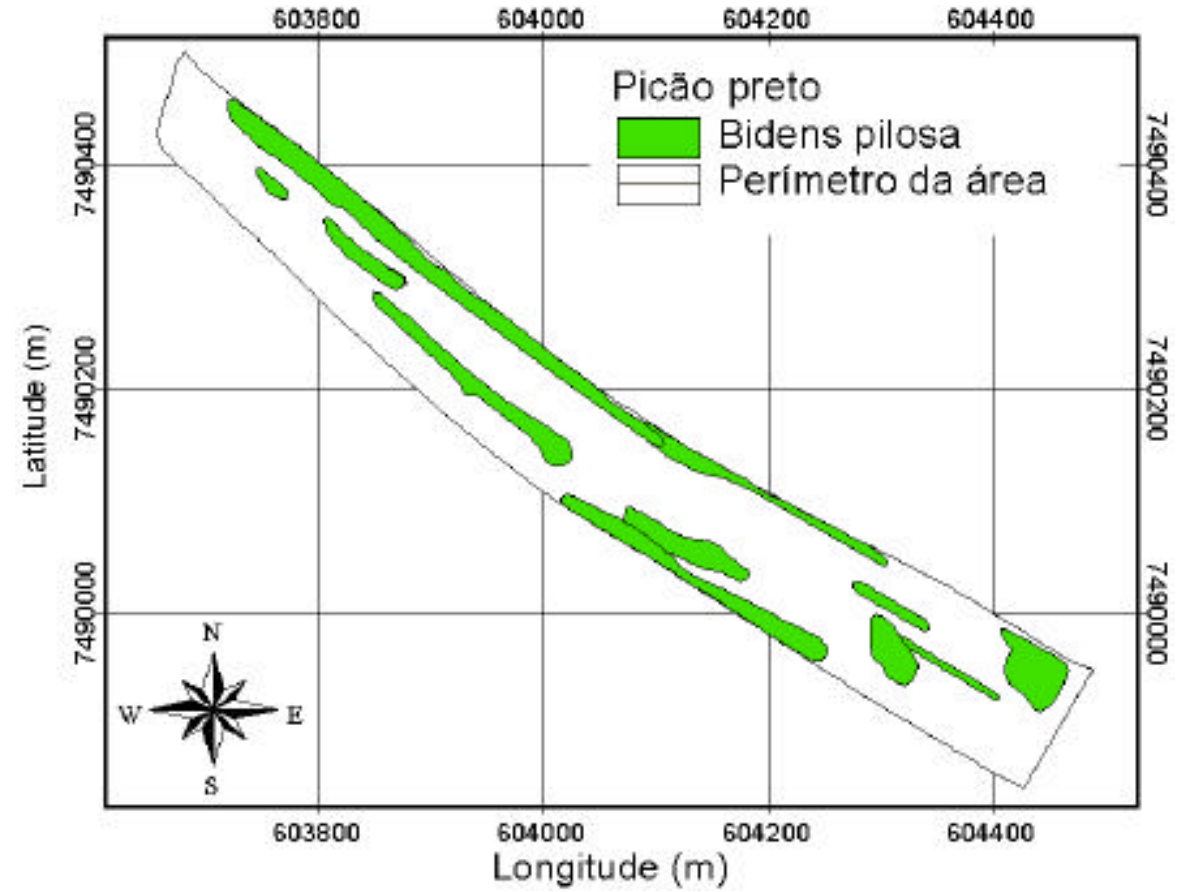

Figura 37 - Ilustração da variabilidade espacial da planta daninha picão preto mapeada pela metodologia do contorno das manchas de ocorrência. 
Observa-se nas Figuras 32 a 37 que o padrão da distribuição espacial das plantas daninhas seguiu o padrão de semeadura das fileiras de plantio das culturas, instaladas na área experimental, ao longo dos anos, no sistema de plantio direto. Isto pode ser explicado pela interferência na dispersão das sementes das plantas daninhas pelo maquinário agrícola, que realiza as operações agrícolas durante os tratos culturais e a colheita.

Por esta metodologia de mapeamento, as plantas daninhas foram mapeadas em trinta minutos, necessitando de apenas uma pessoa para a realização do levantamento dos dados em campo.

\subsubsection{Mapas dos atributos da fertilidade do solo}

As Figura 38 a 51 ilustram a variabilidade espacial de todos os atributos da fertilidade do solo mapeados.

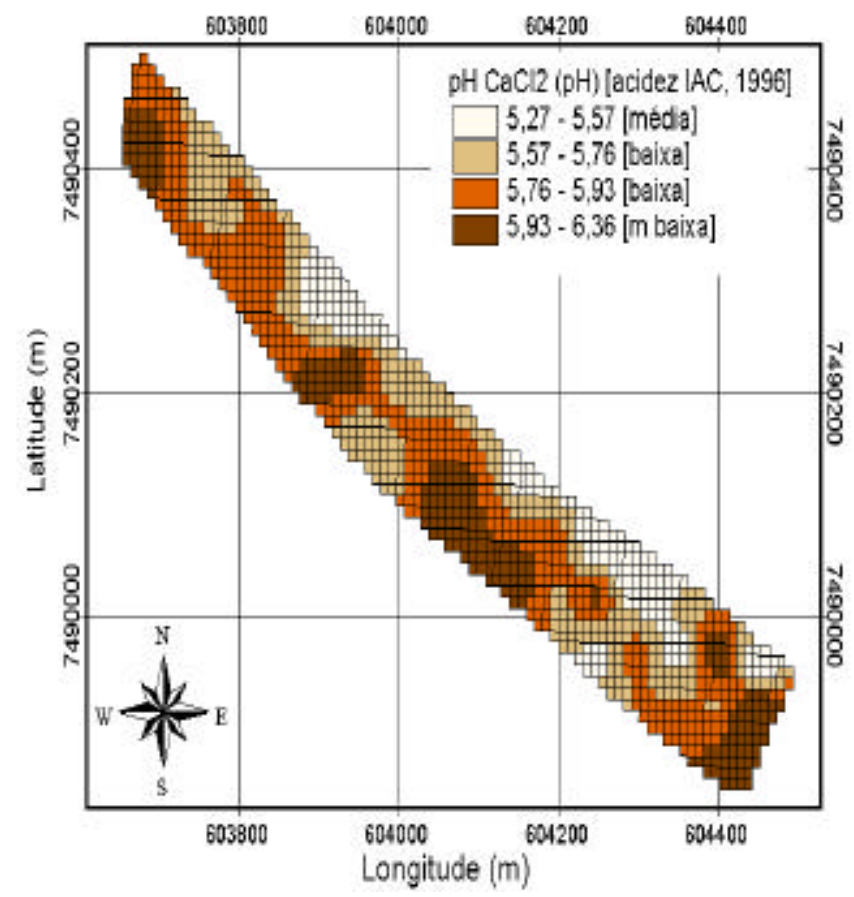

Figura 38 - Ilustração da variabilidade espacial do $\mathrm{pH} \mathrm{CaCb}$ do solo na área experimental. 


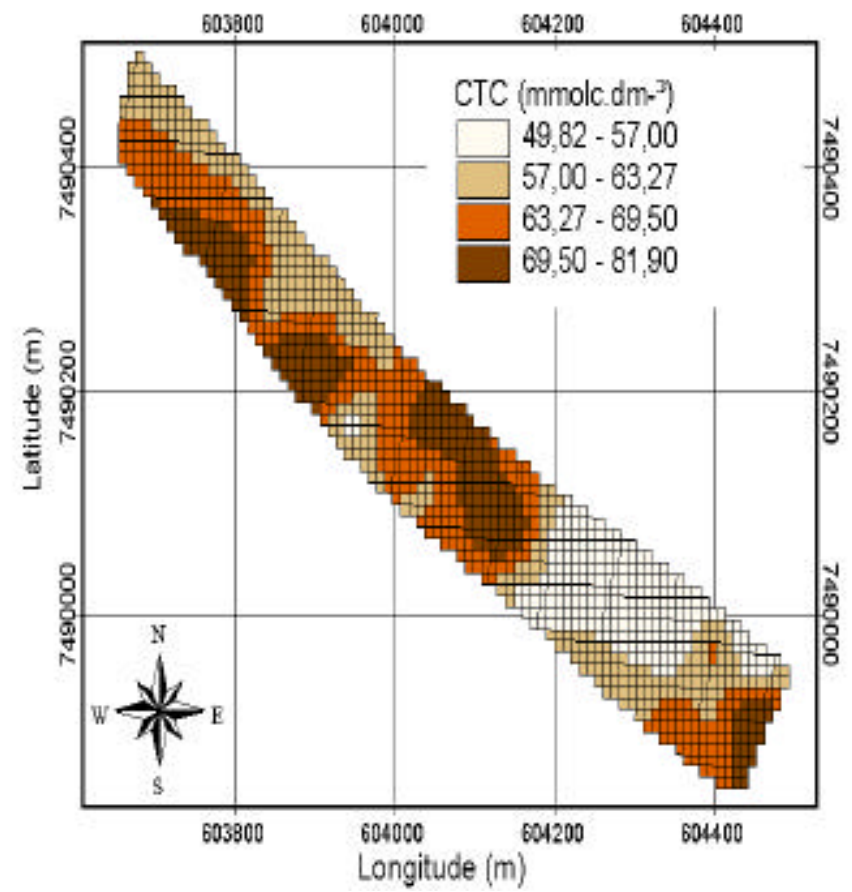

Figura 39 - Ilustração da variabilidade espacial da Capacidade de Troca de Cátions do solo na área experimental.

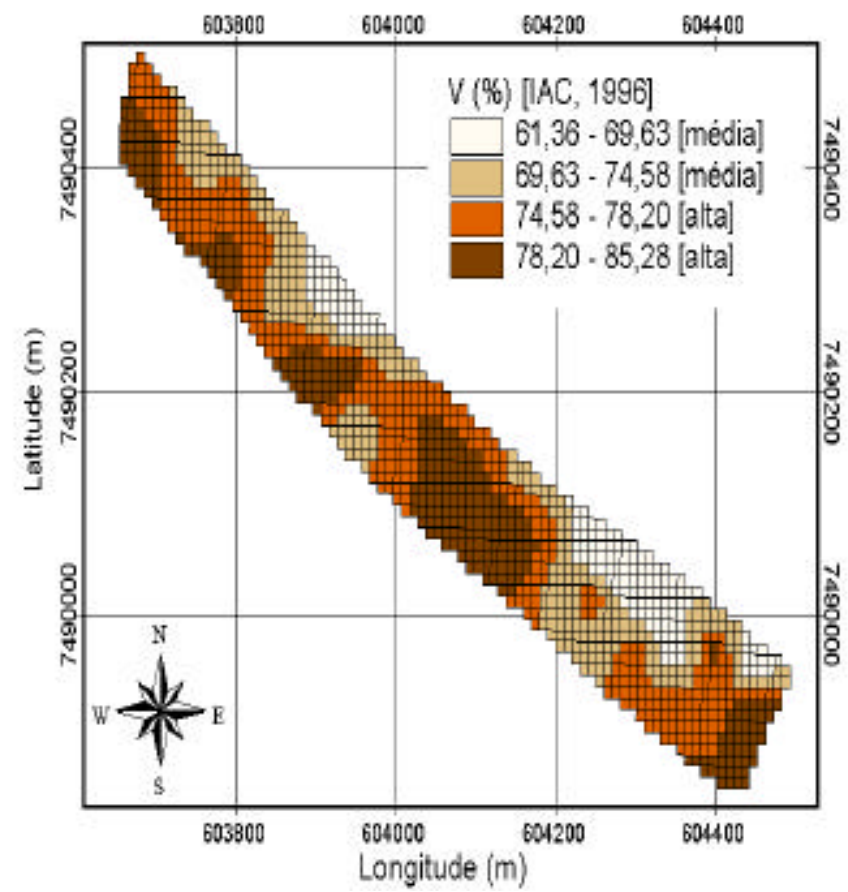

Figura 40 - Ilustração da variabilidade espacial da Saturação por Bases na área experimental. 


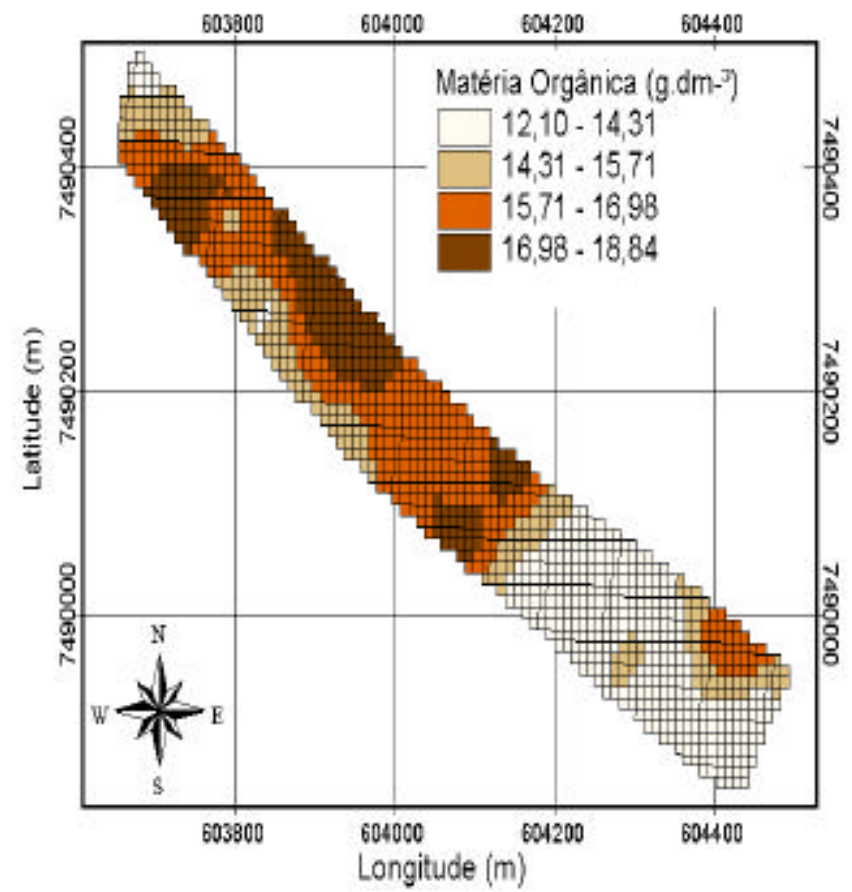

Figura 41 - Ilustração da variabilidade espacial do teor da Matéria Orgânica do solo na área experimental.

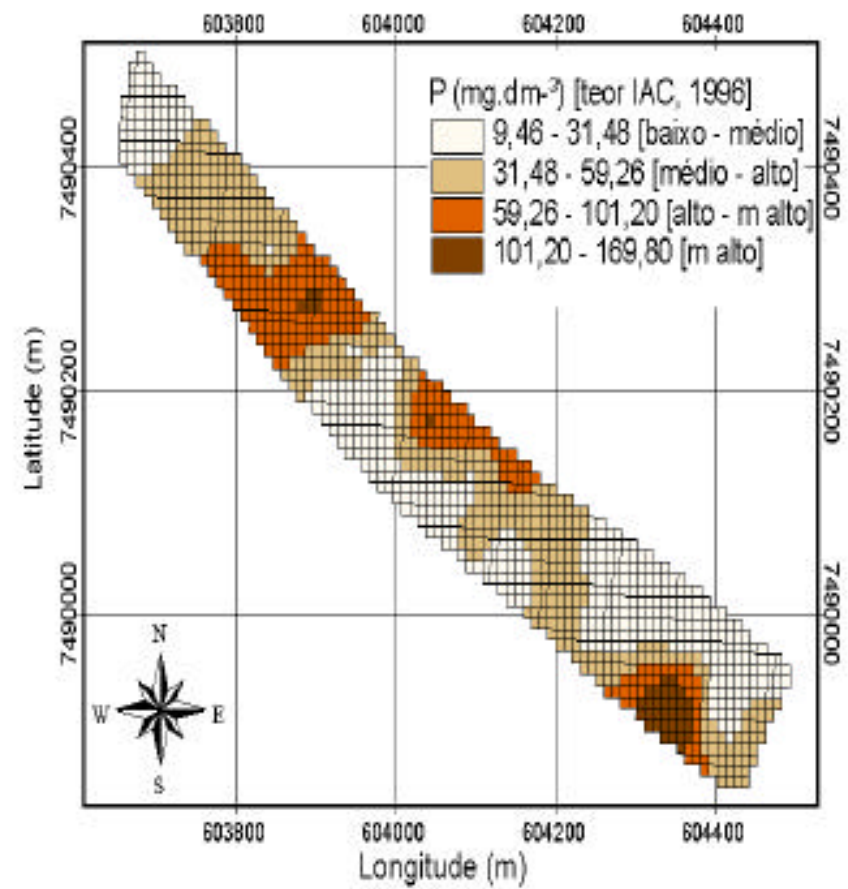

Figura 42 - Ilustração da variabilidade espacial teor de Fósforo do solo na área experimental. 


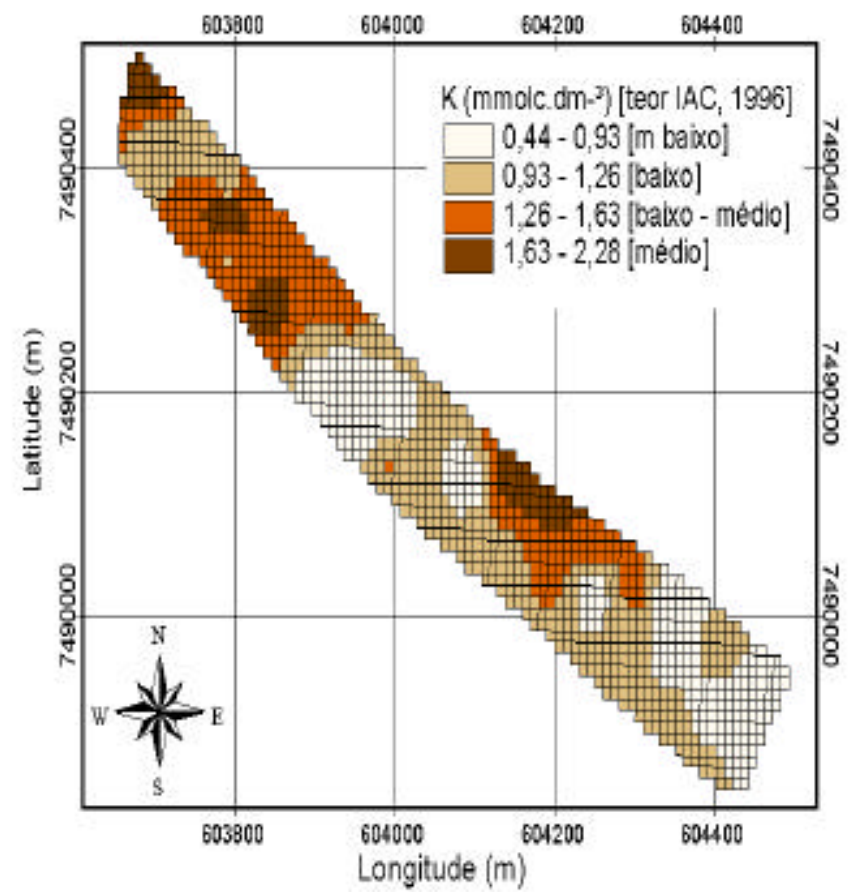

Figura 43 - Ilustração da variabilidade espacial teor de Potássio do solo na área experimental.

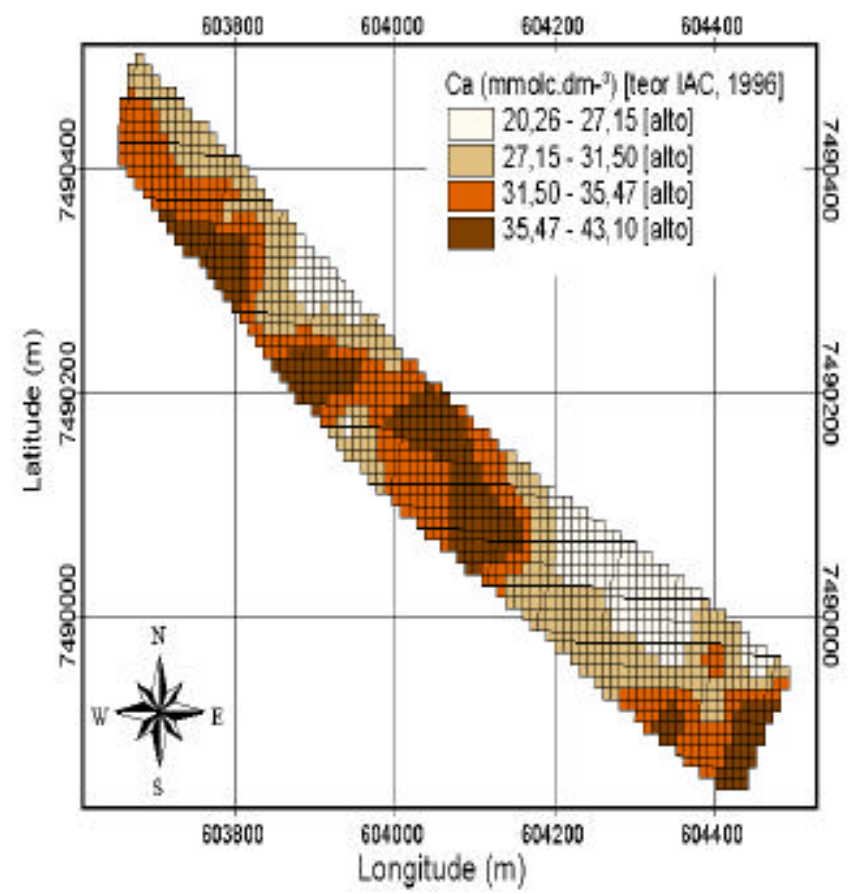

Figura 44 - Ilustração da variabilidade espacial teor de Cálcio do solo na área experimental. 


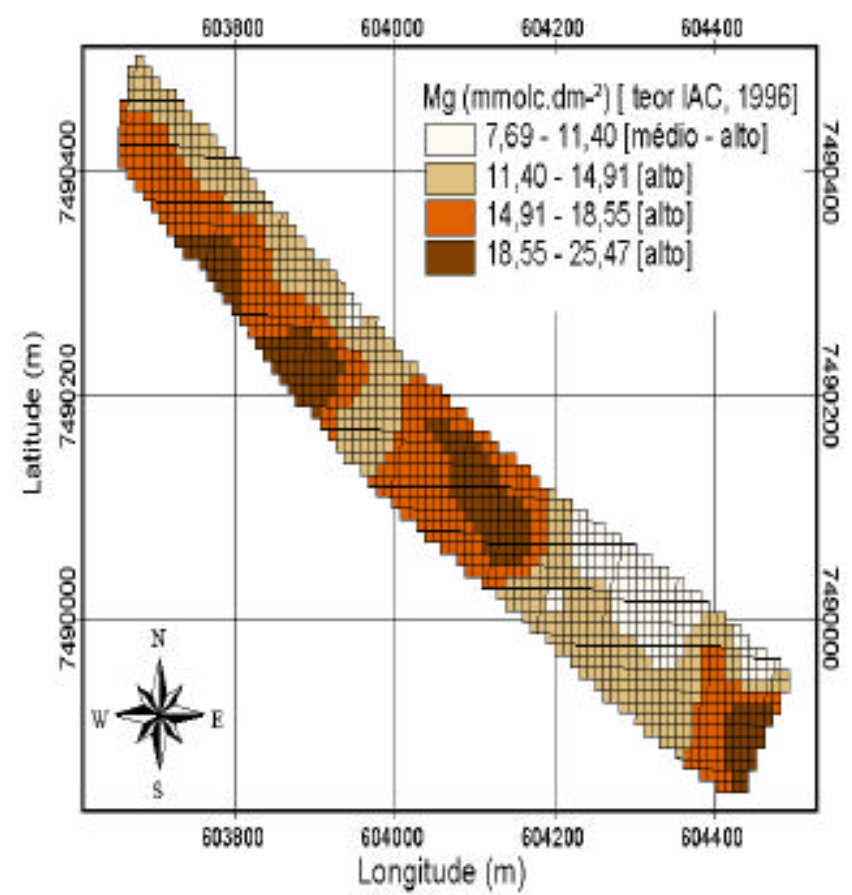

Figura 45 - Ilustração da variabilidade espacial teor de Magnésio do solo na área experimental.

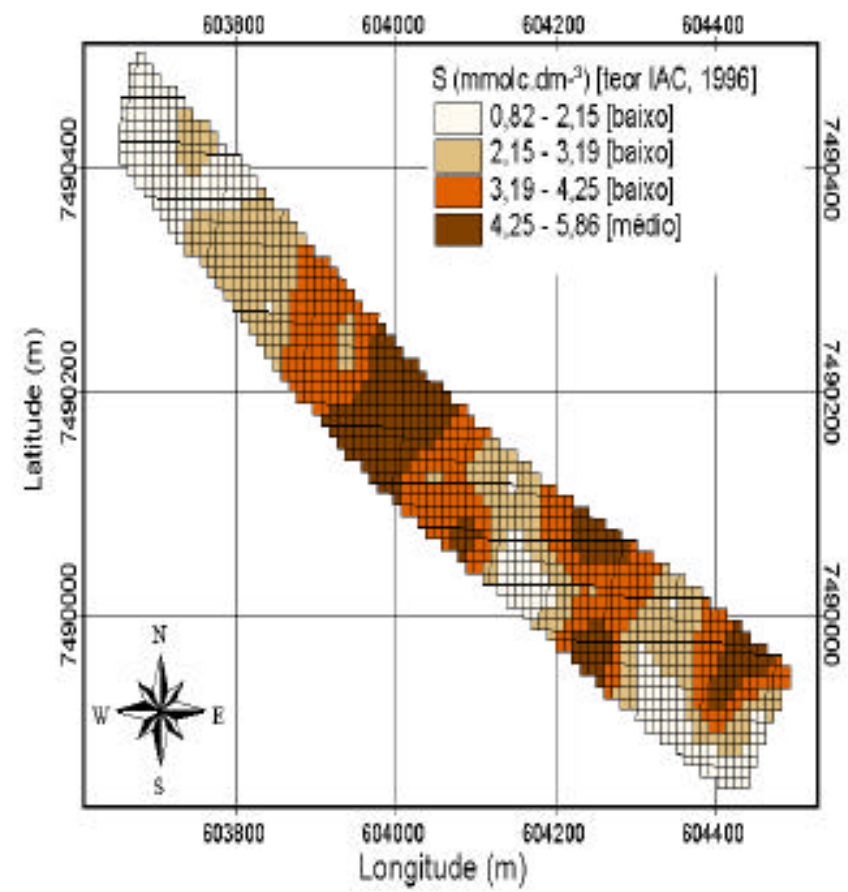

Figura 46 - Ilustração da variabilidade espacial teor de Enxofre do solo na área experimental. 


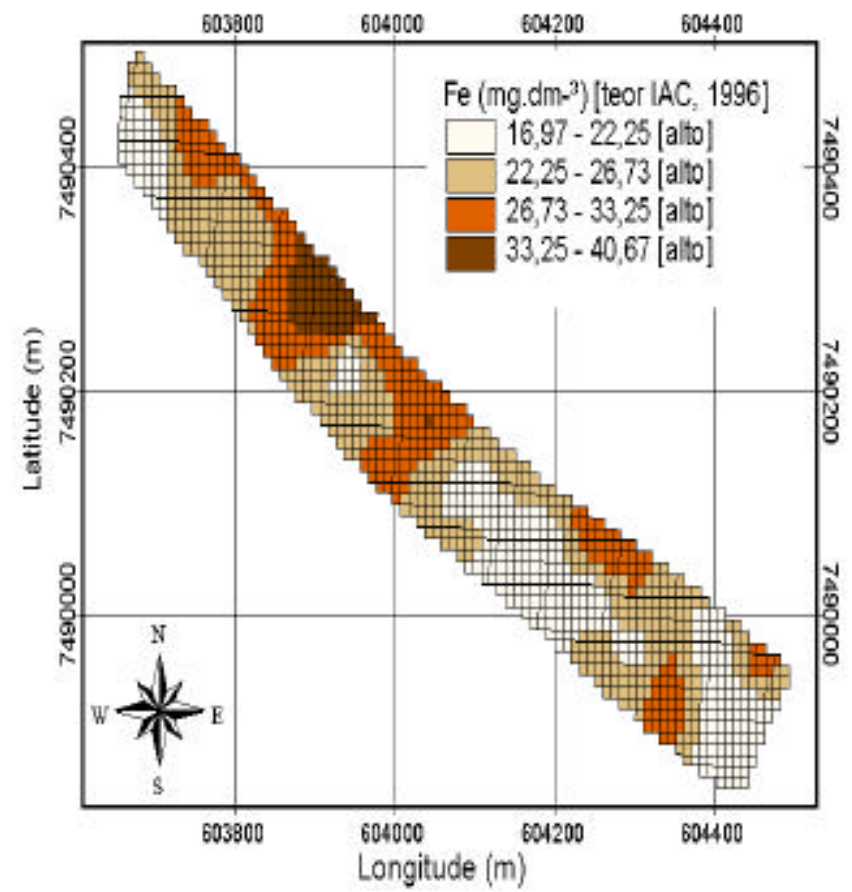

Figura 47 - Ilustração da variabilidade espacial teor de Ferro do solo na área experimental.

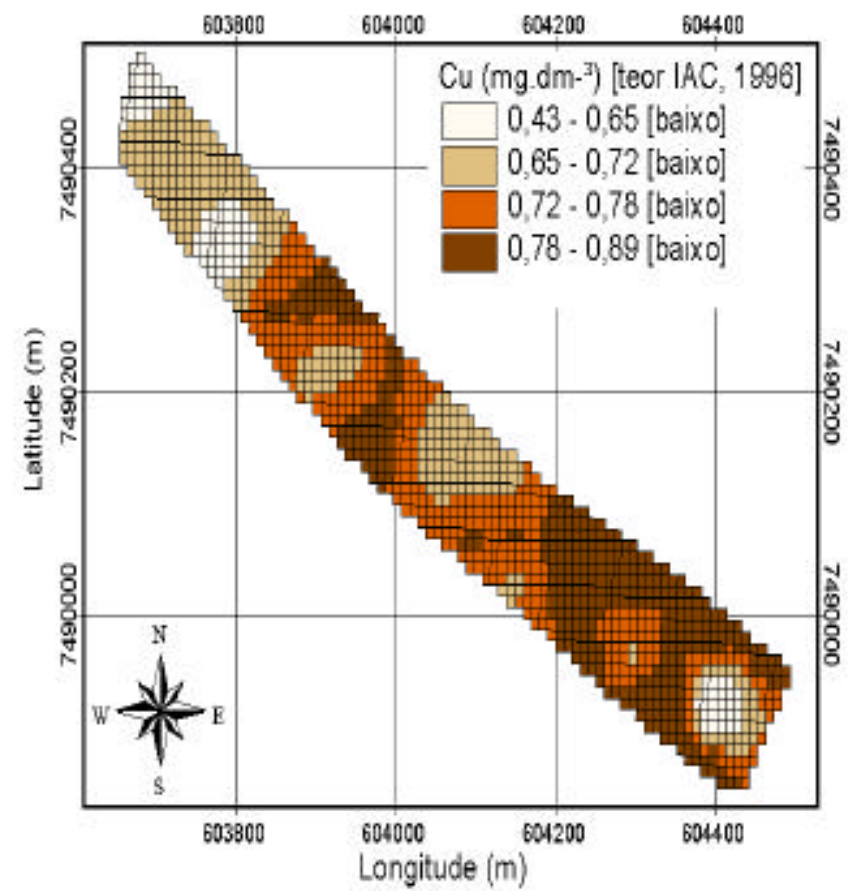

Figura 48 - Ilustração da variabilidade espacial teor de Cobre do solo na área experimental. 


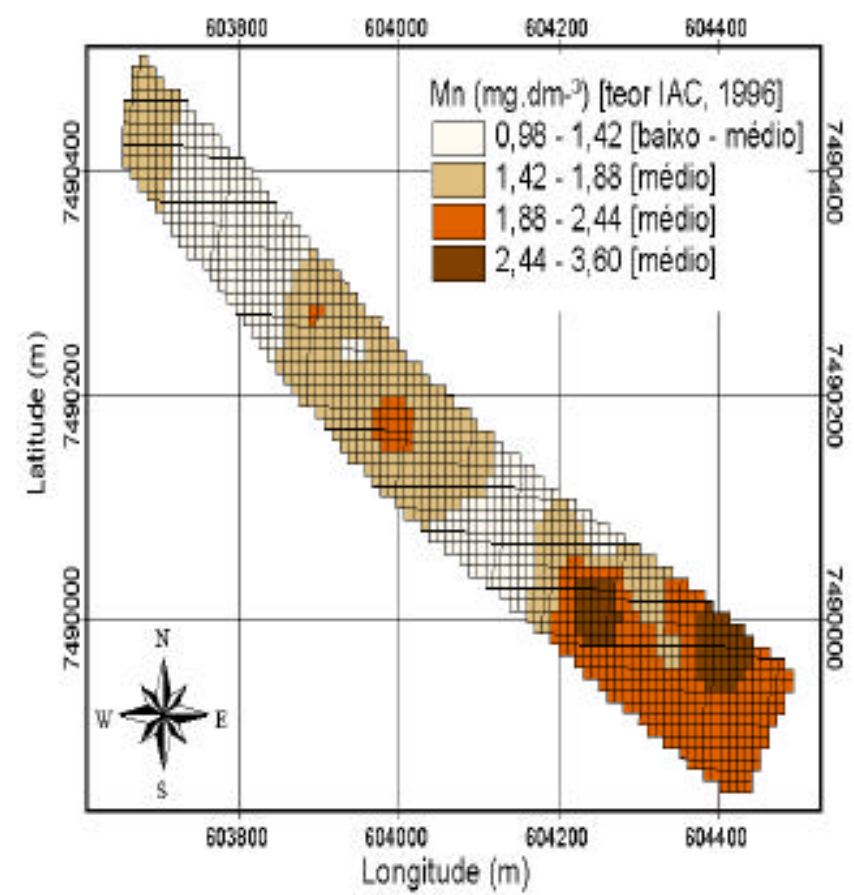

Figura 49 - Ilustração da variabilidade espacial teor de Manganês do solo na área experimental.

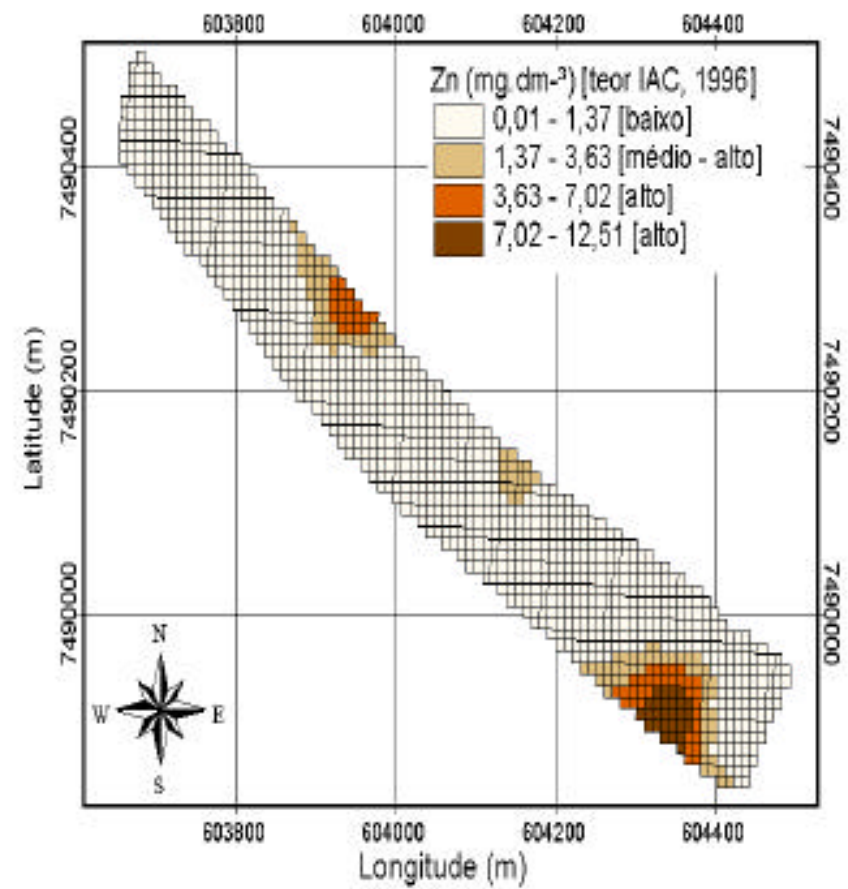

Figura 50 - Ilustração da variabilidade espacial teor de Zinco do solo na área experimental. 


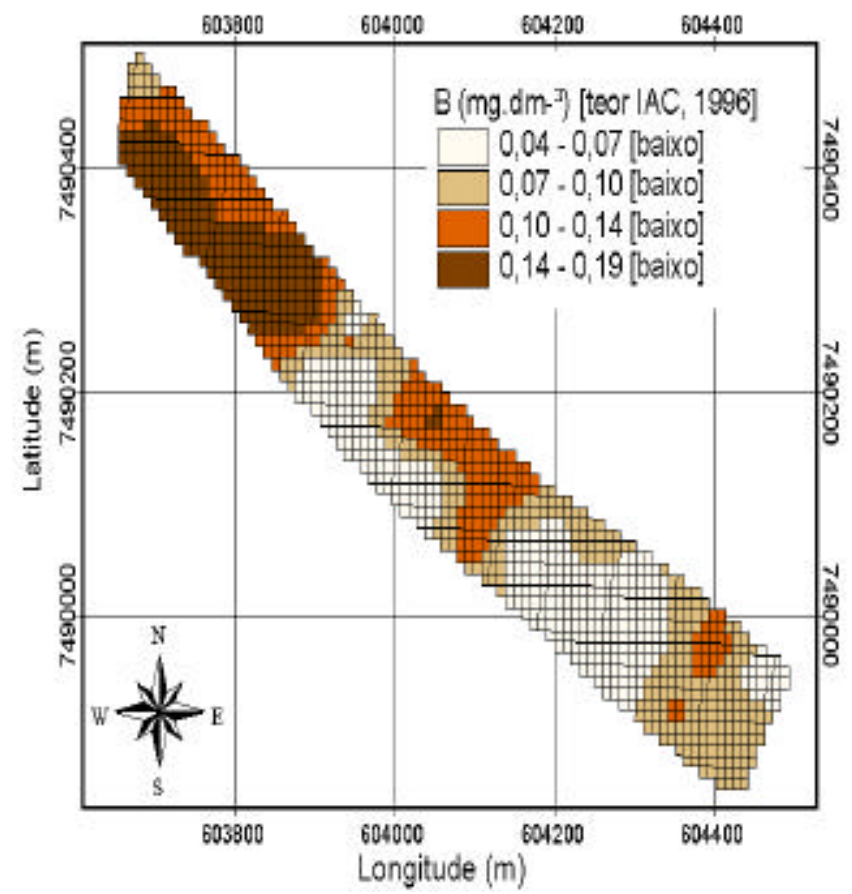

Figura 51 - Ilustração da variabilidade espacial teor de Boro do solo na área experimental.

Pode-se notar nas Figuras 38 a 51 que o nível de fertilidade química do solo é elevado para quase todos os atributos mapeados, de acordo com os padrões de fertilidade química do solo para o Estado de São Paulo (Raij et al., 1996), exceto para os teores dos nutrientes potássio e boro. Isto é devido as adubações realizadas para a implantação e a manutenção das culturas de milho e soja na área experimental durante os últimos anos de cultivo no sistema de plantio direto.

A disposição da classificação dos teores dos atributos da fertilidade mapeados (Raij et al., 1996) na mesma legenda de cada mapa permitiu a visualização do nível da fertilidade do atributo para cada classe ilustrativa da variabilidade espacial. A Figura 51 ilustra a variabilidade espacial do teor do boro na área experimental. Se as classes dos teores mapeados, ilustrados na legenda do mapa, fossem adequadas às divisões propostas por Raij et al. (1996), o mapa perderia a informação ilustrativa da variabilidade espacial do atributo mapeado, uma vez que todas as classes mapeadas seriam dispostas num mesmo nível de fertilidade (nível baixo). A representação da 
variabilidade espacial dos atributos da fertilidade do solo mapeados permitiu a análise da correlação destes com os mapas de plantas daninhas.

Observou-se que a variabilidade espacial dos teores dos nutrientes é elevada. Como pode ser visualizada na Figura 42, que ilustra a variabilidade espacial do teor de fósforo desde o nível baixo até o nível muito alto, mostrando também o potencial da aplicação de fertilizantes a razões variáveis.

\subsection{Aplicação localizada de defensivos}

\subsubsection{Mapa de prescrição}

Após o mapeamento das plantas daninhas pelo método do contorno das manchas de ocorrência foi gerado o mapa de prescrição de herbicida, visando a aplicação localizada de defensivos.

O mapa de prescrição utilizado para a aplicação localizada do herbicida a razões variáveis está ilustrado na Figura 52.

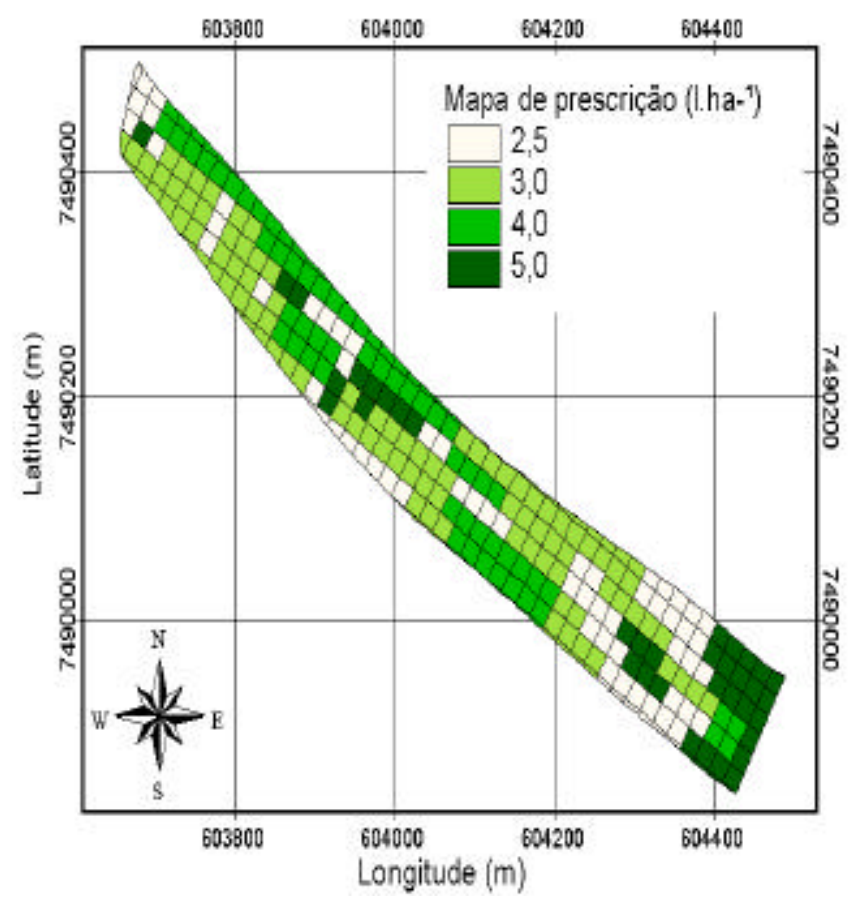

Figura 52 - Mapa de prescrição utilizado na aplicação localizada do defensivo. 
A elaboração do mapa de prescrição permitiu a realização da aplicação localizada de defensivos a razões variáveis com quatro dosagens diferentes de herbicida: 2,5 1.ha' ${ }^{-1}$ (23,8\% da área), 3,0 1.ha ${ }^{-1}$ (37,3\% da área), 4,0 1.ha ${ }^{-1}$ (24,1\% da área) e 5,0 1.ha ${ }^{-}$ 1 (14,8\% da área).

\subsubsection{Mapa da aplicação}

A Figura 53 mostra a sobreposição do mapa da aplicação sem correção ao mapa de prescrição. Pode-se observar que não houve uma coincidência entre a dosagem indicada num determinado ponto georreferenciado do mapa da aplicação e a dosagem indicada para aquele local do mapa de prescrição, como foi descrito no item 3.9.3, sendo necessária a correção deste mapa, onde a dosagem do defensivo num determinado ponto georreferenciado foi transferida para o ponto à frente, correspondente à distância percorrida pelo pulverizador naquele trajeto, de acordo com a velocidade e o tempo de resposta.

A Figura 54 ilustra a sobreposição do mapa da aplicação corrigido sobre o mapa de prescrição. 


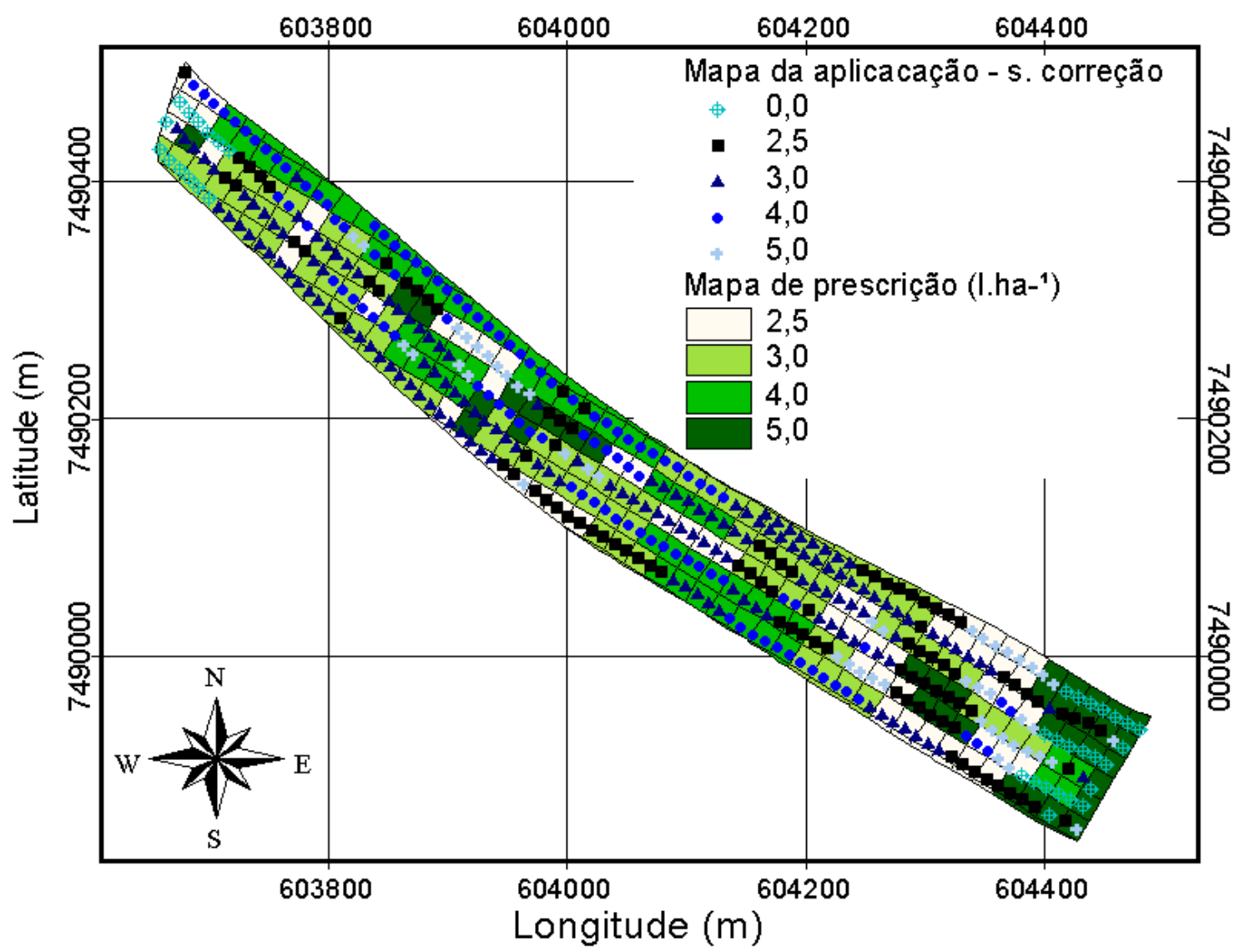

Figura 53 - Sobreposição do mapa de aplicação sem correção ao mapa de prescrição. 


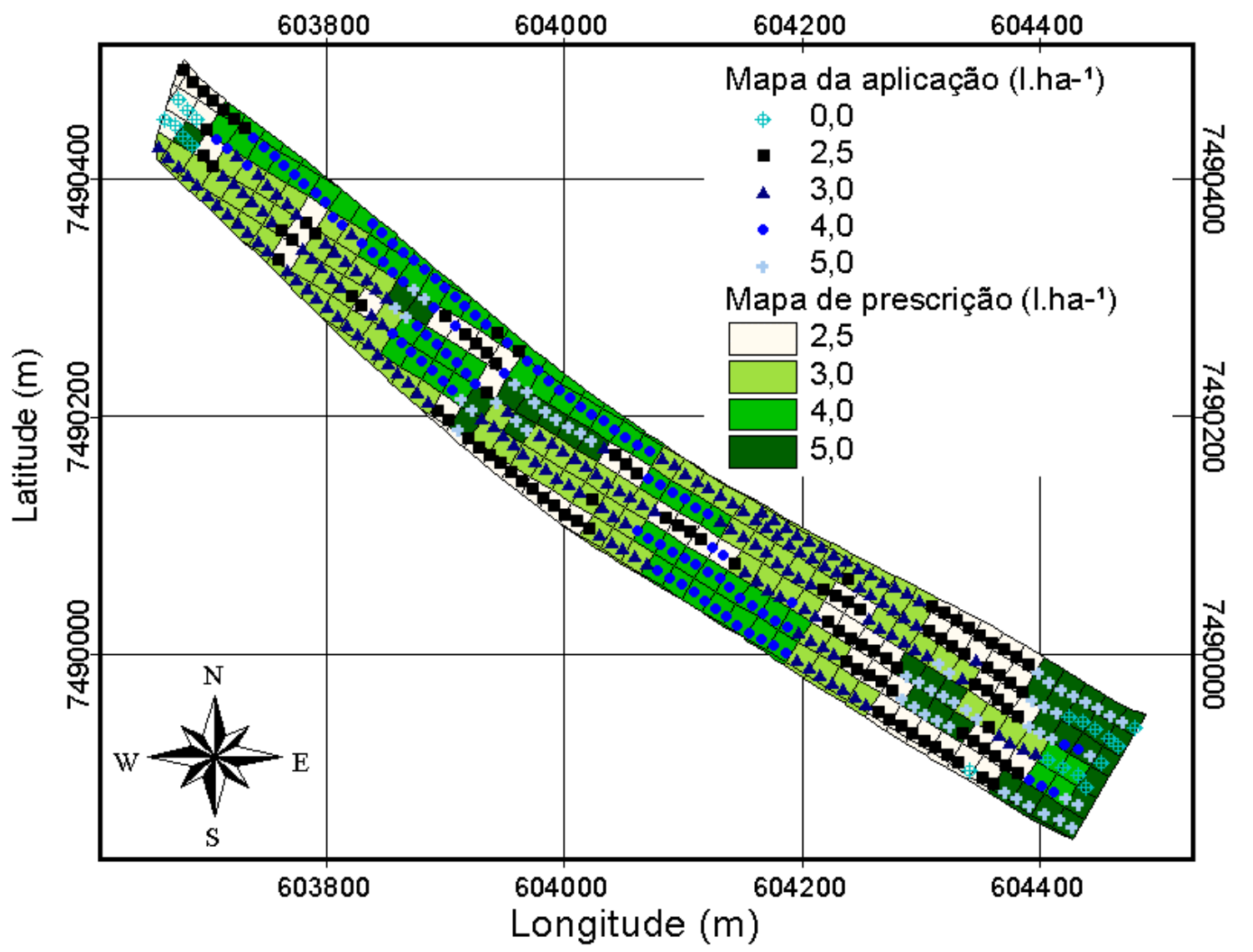

Figura 54 - Sobreposição do mapa da aplicação corrigido ao mapa de prescrição. 
É possível verificar na Figura 54 que houve uma coincidência entre a dosagem indicada no mapa da aplicação e a dosagem indicada no mapa de prescrição após a correção, mostrando que o sistema para aplicação localizada de defensivos aplicou as dosagens recomendadas pelo mapa de prescrição sobre o alvo planejado. Porém, pode-se observar também que alguns pontos apresentaram dosagem diferente daquela recomendada para aquele local. Isto foi devido ao elevado tempo de resposta do sistema associado a erros no alinhamento do trajeto do pulverizador durante a aplicação.

Os pontos ilustrados na Figura 54 com dosagens aplicadas diferentes das indicadas no mapa de prescrição, no início e no final da área experimental, correspondem a pontos onde houve a aplicação da dosagem 0 1.ha ${ }^{-1}$. Este erro na dosagem aplicada foi devido ao elevado tempo de resposta do sistema, pois quando o pulverizador se aproximou do final daquele alinhamento, como também fora dos limites da área, o sistema interrompeu a injeção do defensivo, entendendo que deveria aplicar a dosagem 0 1.ha ${ }^{-1}$ nestes locais. A interrupção da injeção do defensivo no sistema por alguns instantes fez com que houvesse calda remanescente com dosagem 01. ha $^{-1}$ até o momento em que houve o reinício da injeção do defensivo no sistema. Isto ocorreu pois as manobras do pulverizador foram realizadas fora dos limites da área experimental.

A Figura 55 destaca um ponto o qual apresentou dosagem aplicada (ponto em azul ao final do alinhamento em vermelho) diferente da recomendada. Esta ilustração mostra o erro no alinhamento do trajeto do pulverizador durante a aplicação promovendo o aparecimento de pontos no mapa da aplicação com dosagem diferente da recomendada no mapa de prescrição, devido ao elevado tempo de resposta. Pode-se constatar que uma pequena mudança no trajeto do pulverizador no início do alinhamento, corrigido logo em seguida, fez com que houvesse a mudança da dosagem injetada no sistema de 2,5 para $01 . \mathrm{ha}^{-1}$, pois o sistema calculou que estaria fora da área experimental $28 \mathrm{~s}$ após aquele instante, local onde o mapa de prescrição indicava a aplicação da dosagem 0 1.ha ${ }^{-1}$. 


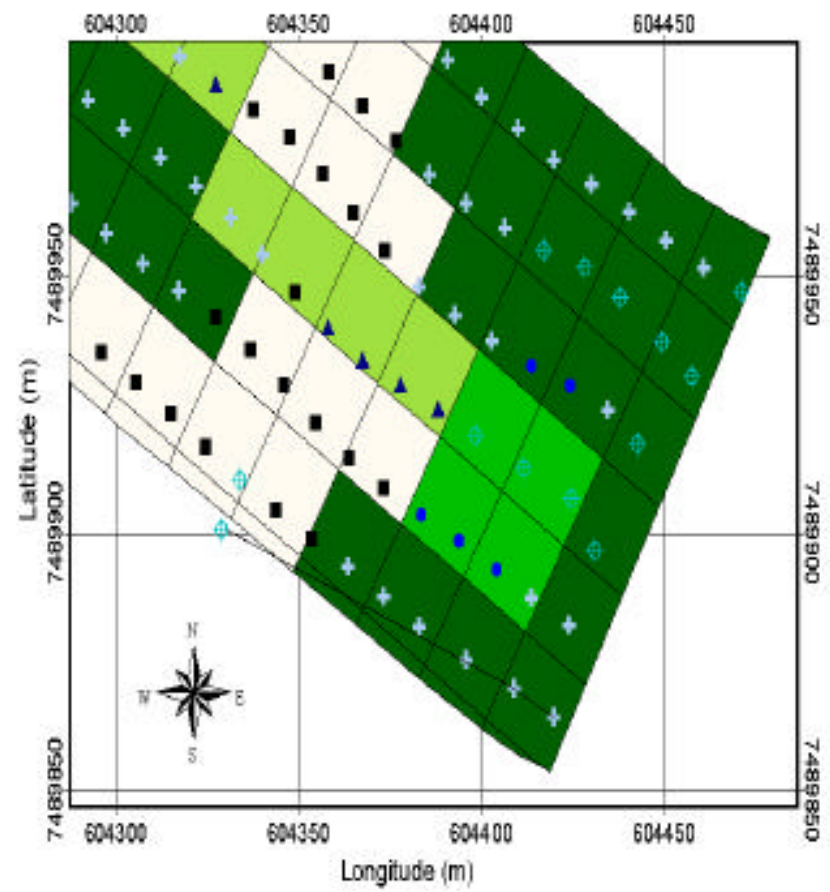

Figura 55 - Erro de trajetória do pulverizador durante a aplicação promovendo o surgimento de pontos no mapa da aplicação com dosagem diferente da recomendada no mapa de prescrição.

Para equipamentos com elevado tempo de resposta, o problema da aplicação da dosagem 0 l.ha ${ }^{-1}$ dentro da área a ser tratada pode ser solucionado pela utilização de uma bordadura ("buffer") com uma dosagem que garanta o controle das plantas daninhas na área, localizada ao redor do perímetro da área (Figura 56).

Esta bordadura deve ter largura $(\mathrm{m})$ correspondente ao tempo de resposta (s) do sistema e na velocidade de aplicação $\left(\mathrm{m} \cdot \mathrm{s}^{-1}\right)$. 


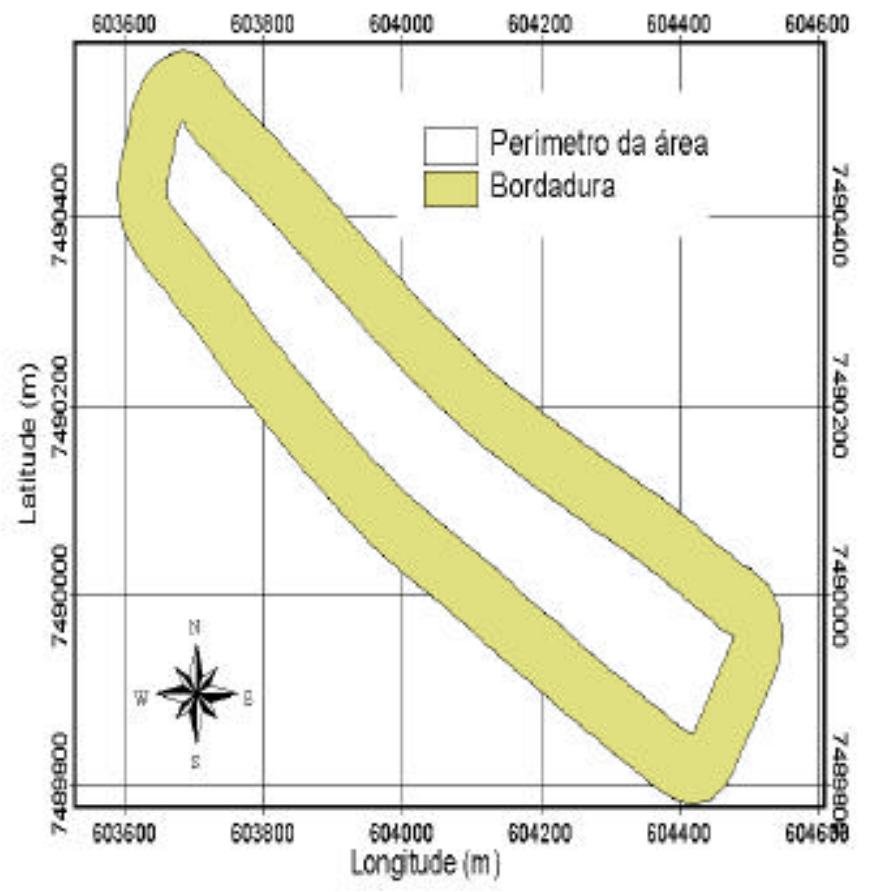

Figura 56 - Bordadura (“buffer”) ao redor do perímetro da área experimental.

O número de pontos no mapa da aplicação onde foi aplicada a dosagem diferente da recomendada correspondeu a $8 \%$ do total. Com a utilização da bordadura sugerida anteriormente, o número de pontos do mapa da aplicação apresentando dosagens diferentes das recomendadas poderia ser reduzido para 2,7\%, que correspondem aos pontos ao centro do mapa da aplicação que ainda apresentariam a dosagem aplicada diferente da recomendada devido a erros do alinhamento no trajeto do pulverizador.

\subsubsection{Verificação do controle das plantas daninhas e economia do herbicida alcançada pela utilização do sistema}

A pulverização do herbicida a razões variáveis pelo equipamento de aplicação localizada de defensivos promoveu o controle adequado das plantas daninhas mapeadas na área experimental. As Figuras 57a e 57b mostram o controle das plantas daninhas na área experimental após a ação do herbicida. 


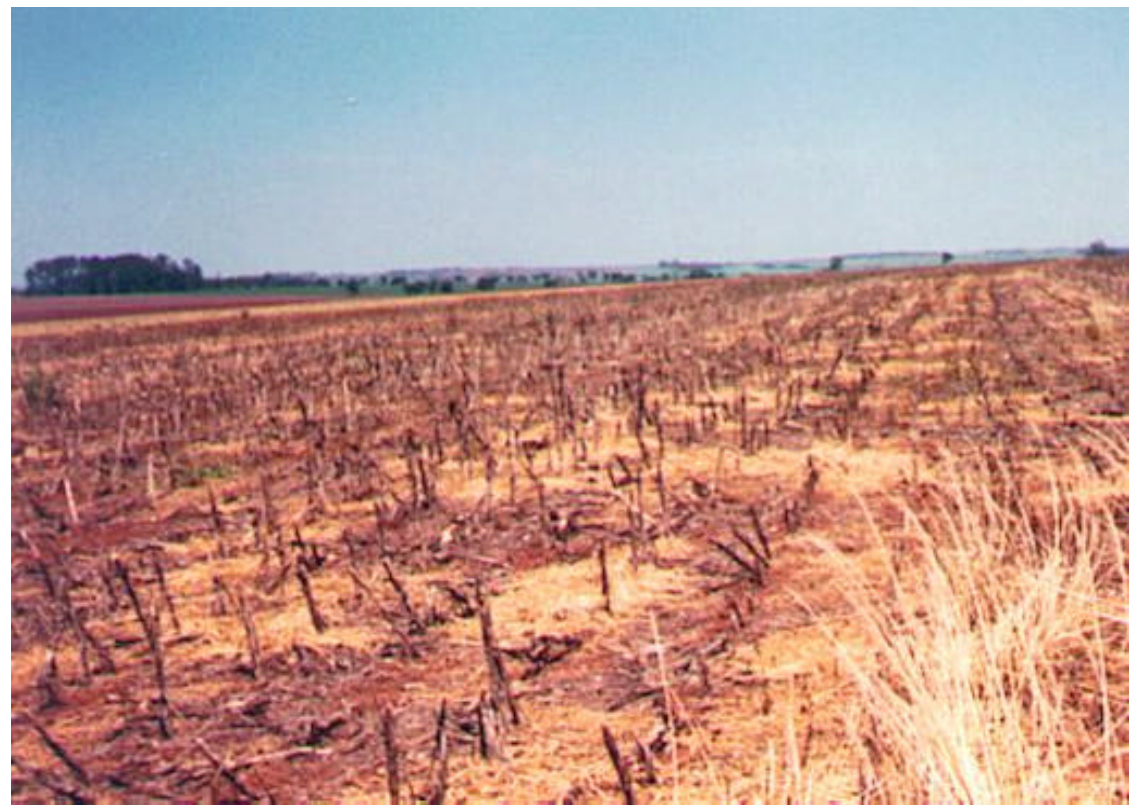

(a)

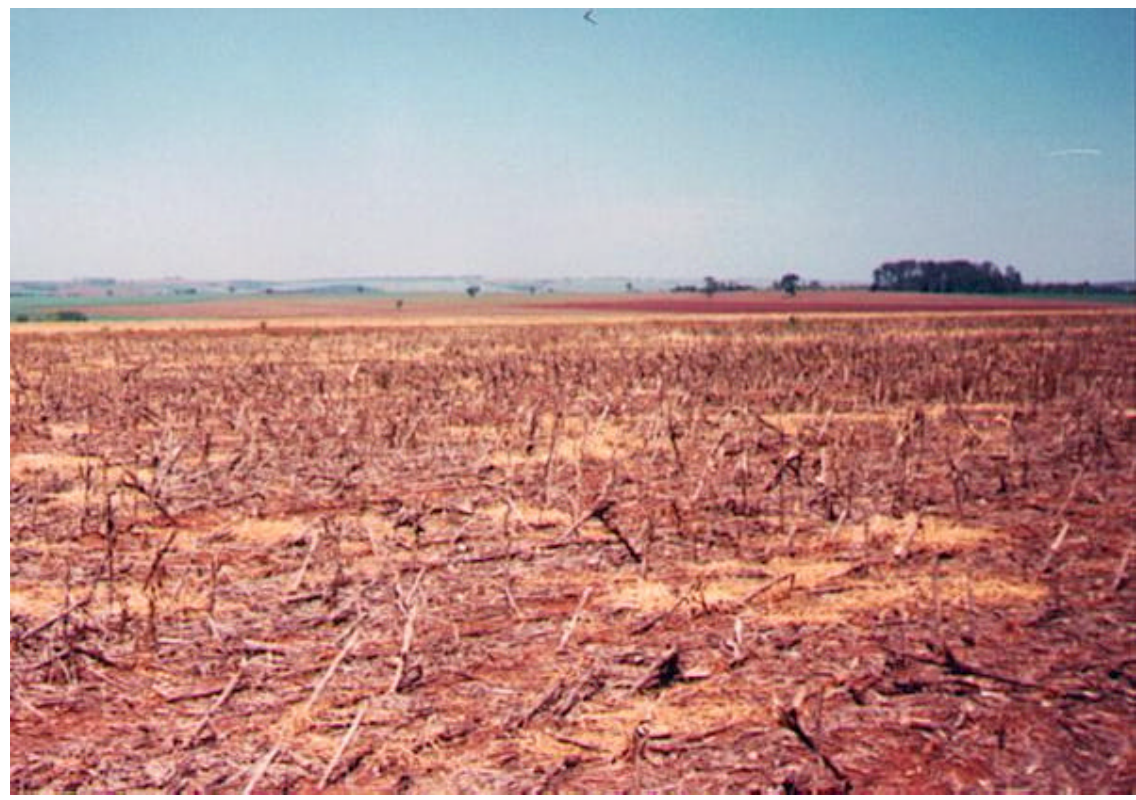

(b)

Figura 57 - Ilustração do controle das plantas daninhas (manchas claras) em duas regiões da área experimental (a e b).

A Figura 58 ilustra a área mapeada onde as plantas daninhas não foram controladas eficientemente. 


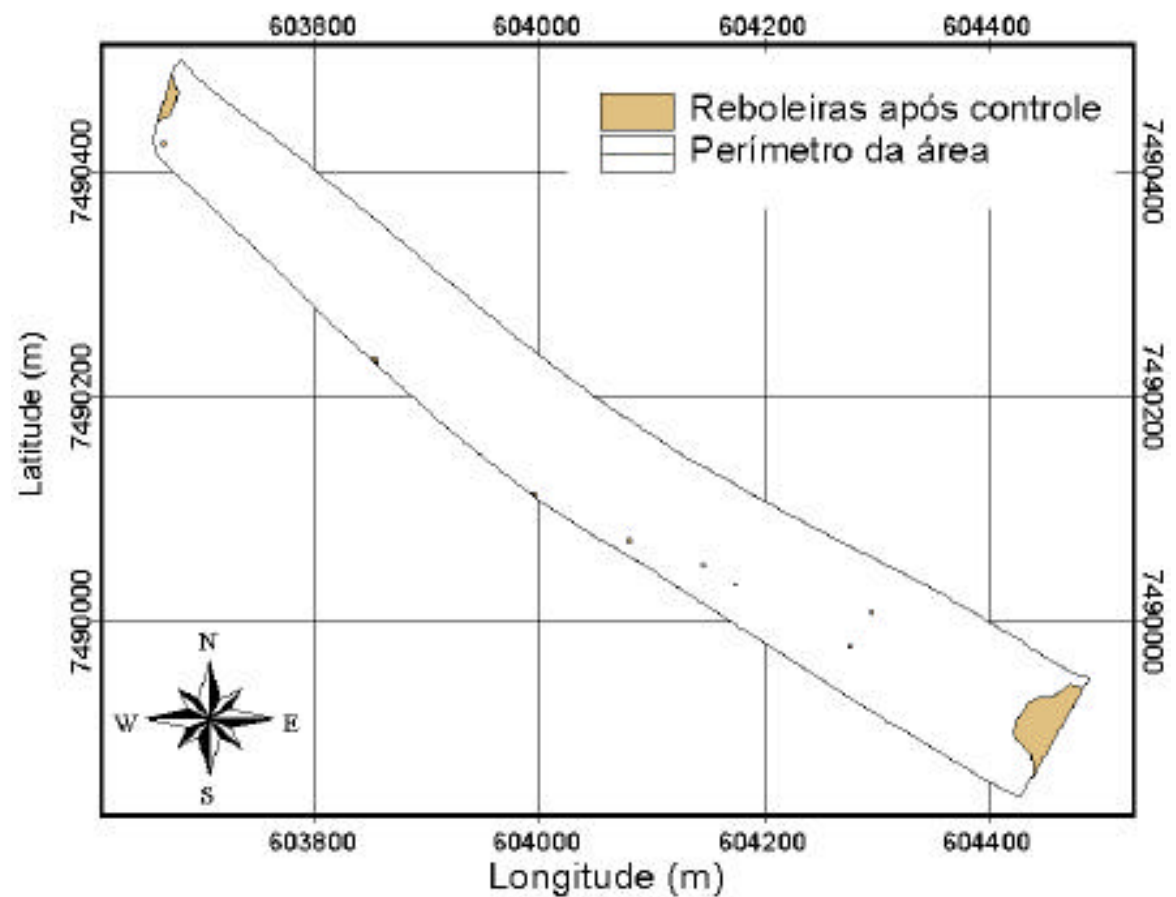

Figura 58 - Ilustração da área mapeada onde as plantas daninhas não foram controladas eficientemente.

A área onde não houve o controle eficiente das plantas daninhas correspondeu a 2,5\% da área total do campo. As manchas maiores, localizadas no início e no final da área, não foram controladas eficientemente devido a aplicação da dosagem 0 1.ha ${ }^{-1}$ naqueles locais. Os pontos no interior da bordadura, ilustrados na Figura 58, correspondem a algumas plantas de leiteiro que não foram controladas eficientemente devido ao seu elevado estágio de desenvolvimento, não sendo suficiente a dosagem do herbicida aplicado sobre aquele local.

O sistema utilizado permitiu uma economia de $31,6 \%$ do herbicida aplicado, quando comparado ao consumo pela aplicação em área total com dosagem única, ilustrando o potencial desta tecnologia. 


\subsection{Comparação entre as metodologias para o mapeamento de plantas da ninhas avaliadas}

O mapeamento de plantas daninhas por amostragens sistemáticas se mostrou muito demorado, exigindo 14 horas para ser executado. Por esta metodologia foram necessárias duas pessoas para o levantamento dos dados em campo pois a navegação até o ponto amostral foi feita sem a ajuda de algum veículo e havia a necessidade do carregamento de um grande conjunto de equipamentos. Porém, esta metodologia promoveu o maior detalhamento da variabilidade espacial dos mapas das plantas daninhas. Mostrou-se pouco prático para ser realizado em áreas extensas, onde poderiam ser utilizados os pulverizadores de grande porte equipados com o sistema para aplicação localizada de defensivos. Porém, a metodologia poderia ser utilizada em áreas com culturas anuais já implantadas pois a observação das plantas daninhas é efetuada somente na área amostral georreferenciada. Observou-se que houve a necessidade de um elevado tempo para a realização das análises estatística e geoestatística dos dados para a posterior elaboração dos mapas de plantas daninhas, quando se utilizou o método de mapeamento por amostragens sistemáticas. A metodologia também é objetiva no levantamento dos dados em campo, já que cabe ao executor somente a verificação das plantas daninhas presentes dentro da área amostral.

O mapeamento das plantas daninhas realizado pela metodologia do contorno das manchas de ocorrência se mostrou mais rápido para ser executado em campo, exigindo somente 30 minutos para ser realizado por somente uma pessoa. Porém, se mostrou uma metodologia na qual exige-se a habilidade da pessoa que está realizando o mapeamento em identificar o perímetro da mancha da planta daninha que está sendo mapeada. Portanto, é uma metodologia subjetiva e que necessita de prática. Observou-se que esta metodologia teria pouca aplicabilidade numa cultura já instalada e em estágio avançado de desenvolvimento, pois haveriam dificuldades em identificar o perímetro das manchas das plantas daninhas devido à barreira visual causada pela cultura.

Portanto, para a elaboração dos mapas de plantas daninhas, visando a criação de mapas de prescrição de herbicidas, a metodologia utilizada deve permitir um mapeamento rápido, deve ser simples e deve ser uma metodologia que possa ser aplicada em áreas extensas. 
A Tabela 7 reúne as informações comparativas sobre as metodologias avaliadas para o mapeamento de plantas daninhas num formato resumido.

Tabela 7. Comparação entre as metodologias de mapeamento de plantas daninhas avaliadas neste estudo.

\begin{tabular}{|c|c|c|}
\hline & $\begin{array}{l}\text { Amostragens } \\
\text { sistemáticas }\end{array}$ & $\begin{array}{c}\text { Contorno das } \\
\text { manchas }\end{array}$ \\
\hline $\begin{array}{l}\mathrm{N}^{\circ} \text { de pessoas utilizadas para o } \\
\text { levantamento dos dados }\end{array}$ & 2 & 1 \\
\hline $\begin{array}{l}\text { Tempo necessário para o } \\
\text { levantamento dos dados (h) }\end{array}$ & 14 & 0,5 \\
\hline $\begin{array}{l}\text { Detalhamento da variabilidade } \\
\text { espacial }\end{array}$ & maior $^{1}$ & menor \\
\hline $\begin{array}{l}\text { Necessidade de análises adicionais } \\
\text { após o levantamento }\end{array}$ & $\begin{array}{l}\text { estatística e } \\
\text { geoestatística }\end{array}$ & não \\
\hline $\begin{array}{l}\text { Necessidade de um SIG para a } \\
\text { elaboração do mapa final }\end{array}$ & $\operatorname{sim}$ & não \\
\hline $\begin{array}{l}\text { Obtenção dos mapas de plantas } \\
\text { daninhas }\end{array}$ & $\begin{array}{l}\text { metodologias de } \\
\text { interpolação }\end{array}$ & $\begin{array}{l}\text { sobreposição dos mapas } \\
\text { obtidos em campo }\end{array}$ \\
\hline $\begin{array}{l}\text { Possibilidade da realização em } \\
\text { culturas anuais implantadas }\end{array}$ & $\operatorname{sim}$ & não \\
\hline $\begin{array}{l}\text { Possibilidade da realização em } \\
\text { áreas extensas }\end{array}$ & não & $\operatorname{sim}$ \\
\hline $\begin{array}{l}\text { Objetividade na coleta dos dados } \\
\text { em campo }\end{array}$ & objetivo & subjetivo \\
\hline
\end{tabular}

Verificou-se que algumas espécies de plantas daninhas que ocorreram em menor densidade em alguns locais da área experimental foram mapeadas por uma metodologia, porém, esta mesma espécie não foi mapeada por outra. Isto aconteceu porque esta planta daninha não ocorreu num nível de infestação alto naquele local do campo para ser mapeada pela metodologia do contorno das manchas de plantas daninhas, ou não estavam presentes dentro da área amostral georreferenciada, para ser mapeada pela metodologia das amostragens sistemáticas. A Figura 59 mostra estas duas situações pela sobreposição dos mapas ilustrativos da variabilidade espacial do capim carrapicho obtidos pelas duas metodologias. 


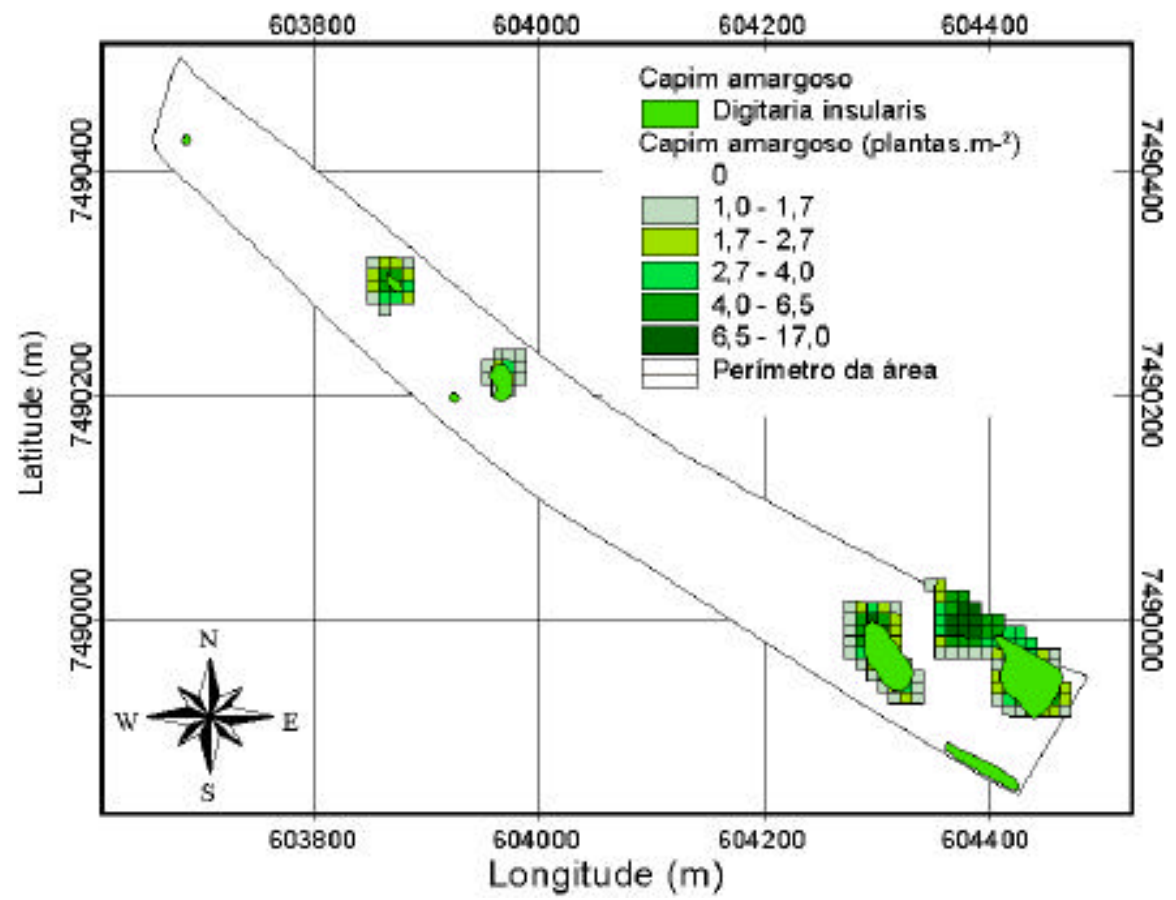

Figura 59 - Sobreposição dos mapas ilustrativos da variabilidade espacial do capim carrapicho obtidos pelas metodologias de mapeamento de plantas daninhas por amostragens sistemáticas e pelo contorno das manchas de ocorrência.

\subsection{Análise da correlação da variabilidade espacial entre as espécies de plantas daninhas e os atributos da fertilidade do solo}

Após a geração dos mapas das variáveis do mapeamento dos atributos da fertilidade do solo e das plantas daninhas foi feita a análise estatística para o estudo da correlação existente entre as variáveis mapeadas.

A Tabela 8 mostra os coeficientes de correlação de Pearson entre os atributos mapeados da fertilidade do solo e do mapeamento de plantas daninhas. Foram utilizados os valores mapeados do estágio de desenvolvimento das plantas daninhas nesta análise, pois são os dados que definem as dosagens nos mapas de prescrição, além da informação da espécie. 
Tabela 8. Coeficientes de Correlação de Pearson entre as variáveis do mapeamento de fertilidade do solo e do mapeamento de plantas daninhas.

\begin{tabular}{|c|c|c|c|c|c|c|}
\hline & Buva & $\begin{array}{c}\text { Capim } \\
\text { amargoso }\end{array}$ & $\begin{array}{c}\text { Capim } \\
\text { carrapicho }\end{array}$ & Leiteiro & Macelinha & $\begin{array}{l}\text { Picão } \\
\text { Preto }\end{array}$ \\
\hline $\mathrm{PH}$ & $0,19^{* *}$ & $-0,11^{* *}$ & $0,28^{* *}$ & $-0,25^{\star *}$ & $0,28^{* *}$ & 0,01 \\
\hline CTC & $0,18^{\star *}$ & $-0,30^{\star *}$ & $0,18^{\star *}$ & $-0,10^{\star *}$ & 0,01 & $-0,15^{\star *}$ \\
\hline V & $0,24^{* *}$ & $-0,23^{* *}$ & $0,31^{* *}$ & $-0,22^{\star *}$ & $0,19^{\star \star}$ & $-0,05^{\star *}$ \\
\hline MO & 0,00 & 0,01 & 0,00 & $0,19^{\star *}$ & $-0,31^{* *}$ & $0,10^{* *}$ \\
\hline $\mathrm{P}$ & $-0,12^{* *}$ & $-0,16^{\star *}$ & 0,09 & $-0,07^{*}$ & $-0,08^{* *}$ & $-0,18^{\star *}$ \\
\hline $\mathrm{K}$ & $-0,09^{* *}$ & $-0,17^{\star *}$ & $0,20^{\star \star}$ & $0,08^{\star \star}$ & $-0,11^{* *}$ & $-0,11^{* *}$ \\
\hline $\mathrm{Ca}$ & $0,18^{* *}$ & $-0,23^{\star *}$ & $0,22^{* *}$ & $-0,15^{\star \star}$ & $0,14^{\star *}$ & $-0,08^{* *}$ \\
\hline $\mathrm{Mg}$ & $0,24^{* *}$ & $-0,29^{\star *}$ & $0,23^{\star \star}$ & $-0,13^{\star *}$ & 0,05 & $-0,17^{\star *}$ \\
\hline $\mathrm{Fe}$ & $-0,22^{* *}$ & $-0,02$ & $-0,14^{\star *}$ & $0,19^{\star *}$ & $-0,30^{*}$ & $-0,01$ \\
\hline $\mathrm{Cu}$ & $-0,15^{\star *}$ & $0,15^{\star *}$ & $-0,10^{\text {** }}$ & $-0,06^{*}$ & $-0,26^{\star *}$ & $-0,05^{\star *}$ \\
\hline Mn & $-0,06^{*}$ & $0,38^{\star *}$ & $-0,18^{*}$ & $-0,17^{\star *}$ & $0,25^{\star *}$ & $0,09^{* *}$ \\
\hline $\mathrm{Zn}$ & $-0,10^{* *}$ & $-0,03$ & $0,05^{\star *}$ & $-0,07^{*}$ & $0,06^{*}$ & $-0,15^{\star *}$ \\
\hline B & $-0,15^{\star *}$ & $-0,11^{* *}$ & $0,12^{\star \star}$ & $0,07^{\star *}$ & $-0,01$ & $-0,02$ \\
\hline
\end{tabular}

significativo ao nível de $5 \%$ de probabilidade;

** significativo ao nível de $1 \%$ de probabilidade.

Como o mapeamento de plantas daninhas por amostragens sistemáticas possui um elevado esforço amostral, o mapeamento dos atributos da fertilidade do solo poderia ser utilizado para auxiliar na geração dos mapas de plantas daninhas (Andreasen \& Streibig, 1991; Walter et al., 1997; Khakural et al., 1999 e Nordmeyer \& Dunker, 1999) e dos mapas de prescrição pelo processo de interpolação por co-krigagem, diminuindo este esforço amostral. Porém, os dados do mapeamento dos atributos da fertilidade do solo somente podem ser utilizados por este processo de co-krigagem quando é detectada uma correlação estatística satisfatória entre as variáveis envolvidas (Vieira, 1995).

No presente estudo, como é observado na Tabela 8, não houve correlação satisfatória entre os níveis da fertilidade do solo e o estágio de desenvolvimento das plantas daninhas. Todas as correlações encontradas fram muito baixas. Este resultado mostra que outros fatores interferiram no desenvolvimento das plantas daninhas mapeadas com uma influência maior do que o nível de fertilidade do solo.

Portanto, somente o mapeamento dos atributos da fertilidade do solo não auxilia na elaboração do mapa de prescrição de um herbicida pós-emergente pelo 
processo de co-krigagem, pois outros fatores também interferiram no crescimento das espécies de plantas daninhas mapeadas.

Porém, pode-se criar o mapa de prescrição de um herbicida pré-emergente ou de um herbicida pré-plantio incorporado baseado na variabilidade espacial de outros atributos, como o teor de matéria orgânica ou a porcentagem de argila do solo. Como exemplo deste trabalho, a variabilidade espacial do teor de matéria orgânica do solo foi mapeada (Figura 41) e foi observado que o valor máximo mostroutse 1,6 vezes maior que o mínimo. Este resultado demonstra que poderia ser elaborado um mapa de prescrição para aplicação localizada de herbicida a razões variáveis, de acordo com o teor de matéria orgânica de cada local do campo. 


\section{CONCLUSÕES}

A metodologia avaliada para determinação do tempo de resposta de um equipamento para aplicação localizada de defensivos mostrourse prática e rápida.

A desconsideração do tempo de resposta do sistema para aplicação localizada de defensivos compromete a resolução espacial da aplicação, tornando-se necessária a utilização de algum sistema computacional que considere o tempo de adiantamento.

Foi possível a identificação e o mapeamento das espécies de plantas daninhas presentes na área experimental por duas metodologias distintas.

A metodologia de mapeamento de plantas daninhas por amostragens sistemáticas se mostrou muito demorada em campo e exigiu um maior tempo para a obtenção dos seus mapas, devido à necessidade da realização das análises estatística e geoestatística. Porém, proporcionou um maior detalhamento da variabilidade espacial das plantas daninhas no campo.

A metodologia de mapeamento de plantas daninhas pelo contorno das manchas de ocorrência mostroutse rápida para o levantamento dos dados em campo e para a elaboração dos mapas resultantes. Porém, se mostrou uma metodologia subjetiva, devido à necessidade da habilidade do executor do mapeamento em delimitar o perímetro da mancha da planta daninha.

O padrão da distribuição espacial das espécies de plantas daninhas seguiu o padrão de semeadura das fileiras das culturas.

Foi possível a criação de um mapa de prescrição com dosagens diferentes de herbicida baseado na variabilidade espacial das espécies de plantas daninhas mapeadas.

O mapa da aplicação foi coerente com o mapa de prescrição. As plantas daninhas mapeadas foram controladas eficientemente. O sistema para aplicação 
localizada de defensivos permitiu uma economia de herbicida, quando comparado à aplicação em área total.

Não houve correlação satisfatória entre a variabilidade espacial dos atributos da fertilidade do solo da área experimental e do estágio de desenvolvimento das espécies de plantas daninhas mapeadas. 


\section{REFERÊNCIAS BIBLIOGRÁFICAS}

AHLGRIMn, P. Perdendo mercado. Agroanalysis, v.20, n.9, p.22-23, set. 2000.

ANDERSON, W.P. Weed science: principles. 2.ed. St. Paul: West Publishing, 1983. $655 \mathrm{p}$.

ANDREASEN, C.; STREIBIG, J.C. Soil properties affecting the distribution of 37 weed species in Danish fields. Weed Research, v.31, n.4, p.181-187, Aug. 1991.

ANTUNIASSI, U.R. Agricultura de precisão: aplicação localizada de agrotóxicos. In: TECNOLOGIA E SEGURANÇA NA APLICAÇÃO DE AGROTÓXICOS, Santa Maria, 1998. Anais. Santa Maria: UFSM, 1998. p.53-63.

ANTUNIASSI, U.R.; GADANHA JÚNIOR., C.D. Aplicação localizada de produtos fitossanitários. In: BORÉM, A.; GIÚDICE, M.P. del.; QUEIROZ, D.M. de; MANTOVANI, E.C.; FERREIRA, L.R.; VALLE, F.X.R. do; GOMIDE, R.L. (Ed.). Agricultura de Precisão. Viçosa: UFV, 2000. cap.8, p.181-202.

ANTUNIASSI, U.R.; MILLER, P.C.H; PAICE, M.E.R. Dynamic and steady-state dose responses of some chemical injection metering systems. In: BRIGHTON CROP PROTECTION CONFERENCE, 1., Brighton, 1997. Proceedings. Brighton: British Crop Protection Council, 1997. p.687-692.

BAIO, F.H.R.; ANGULO FILHO, R.; VETTORAZZI, C.A.; RAFFO, J.G. da G.; ELIAS, A.I. Estudo da exatidão de um GPS operando em duas taxas de aquisição de dados. In: CONGRESSO BRASILEIRO DE ENGENHARIA AGRÍCOLA, 27., Poços de Caldas, 1998. Anais. Viçosa: Sociedade Brasileira de Engenharia Agrícola, 1998. p.347-349.

BALASTREIRE, L.A. Agricultura de precisão. Piracicaba: O autor, 1998. 81p.

BALASTREIRE, L.A. O estado da arte da agricultura de precisão no Brasil. Piracicaba: O autor, 2000. 224p. 
BALASTREIRE, L.A.; BAIO, F.H.R. Avaliação da acurácia de um GPS com correção por algoritmo comparado com um DGPS. /Apresentado como pôster no III Simpósio sobre Agricultura de Precisão, Piracicaba, 2001b/.

BALASTREIRE, L.A.; BAIO, F.H.R. Avaliação de uma metodologia prática para o mapeamento de plantas daninhas. Revista Brasileira de Engenharia Agrícola e Ambiental. v.5, n.2, p.349-352, maio/ago. 2001a.

BILLER, R.H.; HOLLSTEIN, A.; SOMMER, C. Precision application of herbicides by use of optoelectronic sensors. In: PRECISION AGRICULTURE, Warwick, 1997. Proceedings. Oxford: SCI, 1997. v.2. p.451-458.

BLANCO, H.G.; BLANCO, F.M.G. Efeito do manejo do solo na emergência de plantas daninhas. Pesquisa Agropecuária Brasileira, v.26, n.2, p.215-220, fev. 1991.

BLITZKOW, D. NAVSTAR/GPS: Um Desafio Tornado Realidade. In: SIMPÓSIO BRASILEIRO DE GEOPROCESSAMENTO, 3., São Paulo, 1995. Anais. São Paulo: USP, 1995. p.429-462.

BROULIK, B.L.; DALSTED, K.J.; CLAY, S.AA.; CLAY, D.E.; CARLSON, C.G.; ELLSBURY, M.M.; MALO, D.D Weed detection in field corn using high resolution multiespectral digital imagery and field scouting. Precision Agriculture, v.1, n.1, p.1409-1415, July 1999.

BROWN, R.B.; STECKLER, J.P.; ANDERSON, G.W. Remote sensing for identification of weeds in no-till corn. St. Joseph: ASAE, 1991. 16p. (ASAE Paper, 1050)

CÂMARA, G.; MEDEIROS, J.S. Mapas e suas representações computacionais. In: ASSAS, E.D.; DANO, E.E. (Ed.) Sistema de informações geográficas. Brasília: Embrapa, 1998. cap.2, p.13-29.

CAMBARDELLA, C.A.; MOORMAN, T.B.; NOVAK, J.M.; PARKIN, T.B.; KARLEN, D.L.; TURCO, R.F.; KONOPKA, A.E. Field scale variability of soil properties in central Iowa soils. Soil Science Society of America Journal, v.58, n.5, p.1501-1511, Sep. 1994.

CARDINA, J.; JOHNSON, G.A.; SPARROW, D.H. The nature and consequence of weed spatial distribution. Weed Science, v.45, n.3, p.364-373, May/June 1997. 
CHRISTENSEN, S.; HEISEL, T.; BENLLOCH, J.V. Patch spraying and rational weed mapping in cereals. In: PRECISION AGRICULTURE, 4., St. Paul, 1999. Proceedings. Madison: ASA-CSSA-SSSA, 1999. p.773-782.

CHRISTENSEN, S.; NORDBO, E.; KRISTENSEN, K. Weed cover mapping with spectral reflectance measurements. Aspects of Applied Biology, n.37, p.171-179, 1994.

CLARK, R.L.; MCGUCKIN, R.L. Variable rate application technology: An Overview. ln: PRECISION AGRICULTURE, 3., Bloomington, 1996. Proceedings. Madison: ASA-CSSA-SSSA, 1996. p.855-862.

ClAY, D.E.; CARLSON, C.G.; CHANG, J.; CLAY, S.A.A.; MALO, D.D. Systematic evaluation of precision agriculture farming soil sampling requirements. Precision Agriculture, v.1, n.1, p.253-265, July 1999.

CLAY, S.A; LEMS, G.L.; FORCELLA, F.; ELLSBURGY, M.M.; CARLSON, C.G. Sampling weed spatial variability on a fieldwide scale. Weed Science, v.47, n.6, p.674-681, Nov./Dec. 1999.

COLBACH, N.; FORCELLA, F.; JOHNSON, G.A Spatial and temporal stability of weed population over five years. Weed Science, v.48, n.3, p.366-377, May/June 2000.

COLliVER, C. T.; MAXWELL, B. D.; TYLER, D. A.; ROBERTS D. W.; LONG, D. S. Georeferencing wild oat infestations in small grains: Accuracy and efficiency of three weed survey techniques. In: PRECISION AGRICULTURE, 3., Bloomington, 1996. Proceedings. Madison: ASA-CSSA-SSSA, 1996. p.453-463.

EBERLEIN, C.V.; KING, B.A.; GUTTIERI, M.J. Weed management with site specific herbigation. In: PRECISION AGRICULTURE, 4., St. Paul, 1999. Proceedings. Madison: ASA-CSSA-SSSA, 1999. p.869-878.

EHLERT, D.; JÜRSCHIK, P. Techniques for determining heterogeneity for precision agriculture. In: PRECISION AGRICULTURE, Warwick, 1997. Proceedings. Oxford: SCI, 1997. v.2. p.627-634.

ENGQVIST. A.; BENGTSSON, P.; ENFÄLT, P.; ALNESS, K. A model for site specific broad-leaved weed control based on weed plant variables. In: PRECISION AGRICULTURE, Warwick, 1997. Proceedings. Oxford: SCI, 1997. v.2. p.869878. 
FROST, A.R. A pesticide injection metering system for use on agricultural spraying machines. Journal of Agricultural and Engineering Research, v.46, n.1, p.55-70, Jan. 1990.

GAADI, A; AYERS, P.D. Integrating GIS and GPS into a spatially variable rate herbicide application system. Applied Engineering in Agriculture, v.15, n.4, p.255-262, Jul. 1999.

GADANHA JÚNIOR, C.D. Avaliação do tempo de resposta de controladores eletrônicos em pulverizadores agrícolas. Botucatu, 2000. 125p. Tese (Doutorado) Faculdade de Ciências Agronômicas, Universidade Estadual Paulista "Júlio de Mesquita Filho".

GELMINI, G.A.; TRANI, P.E.; SALES, J.L.; VICTÓRIA FILHO, R. Manejo integrado de plantas daninhas. Campinas: IAC, 1994. 24p. (Documentos, 37).

GERHARDS, R.; WYSE-PESTER, D.Y.; JOHNSON, G.A. Characterizing spatial stability of weed populations using interpolated maps. Weed Science, v.45, n.3, p.108-119, Jan./Feb. 1997.

GILES, D.K; HENDERSON, G.W.; FUNK, K. Digital control of flow rate and spray droplet size from agricultural nozzles for precision chemical application. In: PRECISION AGRICULTURE, 3., Bloomington, 1996. Proceedings. Madison: ASA-CSSA-SSSA, 1996. p.729-738.

GOLDEN SOFTWARE. Surfer for windows: user's guide. Golden: Golden Software, 1995. 1v.

GONÇALVES, A.C.A.; FOLEGATTI, M.V.; VIEIRA, S.R. Padrões de amostragem e intensidade de krigagem na caracterização do armazenamento de água no solo, em área irrigada por pivô central. Revista Brasileira da Ciência do Solo, v.23, p.485495, jul/set. 1999.

GOTWAY, C.A.A.; FERGUSON, R.B.; HERGERT,G.W. The effects of mapping and scale on variable-rate fertilizer recommendations for corn. ln: PRECISION AGRICULTURE, 3., Bloomington, 1996. Proceedings. Madison: ASA-CSSASSSA, 1996. p.321-330.

HÄUSLER, A.; NORDMEYER, H. Impact os soil on weed distribution. In: SEMINAR ON SITE SPECIFIC FARMING, Aarhus, 1995. Proceedings. Aarhus: Statens/Planteavlsforsog, 1995. p.186-189. 
HEISEL, T.; ANDREASEN, C.; ERSBOLL, A.K. Annual weed distributions can be mapped with kriging. Weed Research, v.36, n.4, p.325-337, Aug. 1996 a.

HEISEL, T.; CHRISTENSEN, S.; WALTER, A.M. Weed managing model for patch spraying in cereal. In: PRECISION AGRICULTURE, 3., Bloomington, 1996. Proceedings. Madison: ASA-CSSA-SSSA, 1996b. p.999-1007.

HEISEL, T.; CHRISTENSEN, S.; WALTER, A.M. Validation of weed patch spraying in spring barley - preliminary trial. In: PRECISION AGRICULTURE, Warwick, 1997. Proceedings. Oxford: SCI, 1997. v.2. p.879-886.

HEISEL, T.; ERSBOLL, A.K.; ANDREASEN, C. Weed mapping with co-kriging using soil properties. Precision Agricuture, v.1, n.1, p.39-52, Apr. 1999.

RAIJ, B. van; CANTARELlA, H.; QUAGGIO, J.A.; FURLANI, A.M.C. (Ed.) Recomendações de adubação e calagem para o Estado de São Paulo. 2.ed. Campinas: IAC/Fundação IAC, 1996. 285p. (IAC. Boletim Técnico, 100).

ISAAKS, E.H.; SRIVASTAVA, R.M. An introduction to applied geostatistics. New York: Oxford University Press, 1989. 561 p.

JENSEN, T.; HALL, L. Precision farming: working toward an ideal. GPS World, v.10, n.2, p.38-42, Feb. 1999.

JOHNSON, G.A.; CARDINA, J.; MORTENSEN, D.A. Site specific weed management: Current and future directions. In: PIERCE, F.J.; SADLER E.J. (Ed.) The site specific management for agricultural systems. Madison: ASA-CSSASSSA, 1997. cap.7, p.131-147.

KHAKURAL, B.R.; JOHNSON, G.A.; ROBERT, P.C.; MULLA, D.J.; OLIVEIRA, R.; KOSKINEN, W.C. Site specific herbicide management for preserving water quality. In: PRECISION AGRICUlTURE, 4., St. Paul, 1999. Proceedings. Madison: ASA-CSSA-SSSA, 1999. p.1719-1732.

KISER, A.A.; WILLIAMS, B Battling the silent invasion. GPS World, v.11, n.1, p.26-32, Jan. 2000.

KOO, Y.M.; SUMMER, H.R. Total flow control for a direct injection sprayer. Applied Engineering in Agriculture, v.14, n.4, p.363-367, Jul. 1998.

KÖPPEN, W.P. Climatologia, con un studio de los climas de la tierra. Mexico: Fondo de Cultura Econômica, 1948. 478p. 
KRAVCHENKO, A.A.N.; BULLOCK, D.G. Comparison of interpolation Methods for mapping soil P and K contents. Precision Agriculture, v.1, n.1, p.267-509, Apr. 1999.

KROPFF, M.J.; LAAR, H.H.V. Modeling crop-weed interactions. Wallingford: CAB International, 1993. 275p.

LAMB, D.W.; WEEDON, M. Evaluating the accuracy of mapping weeds in fallow fields using airborne digital imaging: Panicum effusum in oilseed rape stubble. Weed Research, v.38, n.6, p.443-451, Dec. 1998.

LANGE, A. F. On datums and geoids. GIS World, v.9, n.10, p.62, Oct. 1996.

LASS, L.W.; CALLIHAN, R.H. GPS and GIS for weed surveys and management. Weed Technology, v.7, n.1, p.249-254, Jan.Mar. 1993.

LIBARDI, P.L.; MANFRON, P.A.; MORAES, S.O.; TUON, R.L. Variabilidade da umidade gravimétrica de um solo hidromórfico. Revista Brasileira da Ciência do Solo, v.20, p.1-12, jan./fev. 1996.

LINDQUIST, J.L.; DIELEMAN, J.A.; MORTENSEN, D.A.; JOHNSON, G.A.; WYSE-PESTER, D.Y. Economic importance of managing spatially heterogeneous weed populations. Weed Technology, v.12, n.1, p.7-13, Jan./Mar. 1998.

LORENZI, H. Manual de identificação e controle das plantas daninhas. 4.ed. Nova Odessa: Plantarum, 1994. 300p.

McBRATNEY, A.B.; PRINGLE, M.J. Spatial variability in soil - implications for precision agriculture. In: PRECISION AGRICULTURE, Warwick, 1997. Proceedings. Oxford: SCI, 1997. v.1. p.3-31.

MIDTECH Mid-Tech TASC 6600. URL: www.mid-tech.com/prod04.html. (15 Oct 2001).

MOHAMED, S.B.;EVANS, E.J., SHIEL, R.S. Mapping tecniques and intensity of soil sampling for precision agriculture. ln: PRECISION AGRICULTURE, 3., Bloomington, 1996. Proceedings. Madison: ASA-CSSA-SSSA, 1996. p.217-226.

MOREIRA, M.A. Fundamentos do sensoriamento remoto. São José dos Campos: INPE, 2001. 250p.

MORGAN, M.; ESS, D. The precision farming: giide for agriculturists. Moline: Deere \& Company, 1997. 117p. 
MORTIMER, A.M. The biology of weeds. In: HANCE, R,J,; HOLLY, K (Ed.) Weed control handbook: principles. London: Blackwell Scientific, 1990. cap.1, p.1-42.

NORDMEYER, H.; DUNKER, M. Variable weed densities and soil properties in a weed mapping concept for patchy weed control. In: PRECISION AGRICULTURE, 4., St. Paul, 1999. Proceedings. Madison: ASA-CSSA-SSSA, 1999. p.453-462.

NORDMEYER, H.; HÄUSLER, A. Spatial distribution of weeds - Geostatistical analysis. In: WORKSHOP ON COMPUTER MODELING IN WEED SCIENCE, Copenhagen, 1996. Proceedings. Copenhagen: Danish Informatics Network in the Agricultural Sciences, 1997. p.44-46.

NORDMEYER, H.; HÄUSLER, A.; NIEMANN, P. Patchy weed control as an approach in precision farming. In: PRECISION AGRICULTURE, Warwick, 1997. Proceedings. Oxford: SCI, 1997. v.1. p.307-314.

NORDMEYER, H.; HÄUSLER, A.; NIEMANN, P. Weed mapping as a tool for patchy weed control. In: INTERNATIONAL WEED CONTROL CONGRESS, 2., Copenhagen, 1996. Proceedings. p.119-123.

NUSPL, S. J.; RUDOLPH, W. W.; GUTHLAND, R. Use of injection for Site-specific Chemical Application. 1n: PRECISION AGRICULTURE, 3., Bloomington, 1996. Proceedings. Madison: ASA-CSSA-SSSA, 1996. p.739-744.

PAICE, M.E.R.; MILLER, P.C.H.; DAY, W. Control requirements for spatially selective herbicide sprayers. Computers and Electronics in Agriculture, v.14, n.2, p.163-177, Feb. 1996.

PAICE, M.E.R.; MILLER, P.C.; LANE, A.G. The response characteristics of a patch spraying system based on injection metering. Aspects of Applied Biology, n.48, p.41-48, 1997.

PAZ-GONZÁLEZ, A.; VIEIRA, S.R.; CASTRO, M.T.T. The effect of cultivation on the spatial variability of selected properties of an umbric horizon. Geoderma, v.97, n.3/4, p.273-292, Sep. 2000.

PÉREZ, AJ.; LÓPEZ, F; BENLLOCH, J.V.; CHRISTENSEN, S. Color and shape analysis techniques for weed detection in cereal fields. Computers and Electronics in Agriculture, v.25, n.3, p.197-212, Feb. 2000. 
POCKNEE, S.; BOYDELL, B.C.; GREEN, H.M.; WATERS, D.J.; KVIEN, C.K. Directed soil sampling. In: PRECISION AGRICULTURE, 3., Bloomington, 1996. Proceedings. Madison: ASA-CSSA-SSSA, 1996. p.159-168.

QIU, W.; WATKINS, G.A.; SOBOLIK, C.J.; SHEARER, S.A. A feasibility study of a direct injection for variable rate herbicide application. Transactions of the ASAE, v.41, n.2, p.291-299, Mar./Apr. 1998.

REW, L.J.; CUSSANS, G.W.; MUGGLESTONE, M.A.; MILlER, P.C.H. A technique for mapping the spatial distribution of Elymus repens, with estimates of the potential reduction in herbicide usage from patch spraying. Weed Research, v.36, n.4, p.283-292, Aug. 1996.

RIZZARDI, M. A.; PIRES, J. L. Resposta de cultivares de milho à distribuição de plantas na linha, com e sem controle de plantas daninhas. Ciência Rural, v.26, n.1, p. 13-17, jan./abr. 1996.

ROCKWELL, A.D.; AYERS, P.D. Variable rate sprayer development and evaluation. Applied Engineering in Agriculture, v.10, n.3, p.327-333, May. 1994.

RODRIGUES, B.N.; ALMEIDA, F.S. Guia de herbicidas. 4.ed. Londrina: Os autores, 1998. 647p.

SADJADI, F. Applications of image understanding technology in Precision Agriculture: Weed classification, and crop row guidance. ln: PRECISION AGRICULTURE, 3., Bloomington, 1996. Proceedings. Madison: ASA-CSSASSSA, 1996. p.779-785.

SÁNCHEZ, P.A. Suelos del trópicos. San José: Instituto Interamericano de Cooperacion para la Agricultura, 1981. 660p.

SCARR, M.R.; TAYLOR, C.C.; DRYDEN, I.L. Automatic recognition of weeds and crops. In: PRECISION AGRICULTURE, Warwick, 1997. Proceedings. Oxford: SCI, 1997. v.2. p.439-446.

STAFFORD, J. V. Essential technology for Precision Agriculture. In: PRECISION AGRICULTURE, 3., Bloomington, 1996. Proceedings. Madison: ASA-CSSASSSA, 1996. p.595-603.

STAFFORD, J.V.; BENLLOCH, J.V. Machine-assisted detection of weeds and weed patches. In: PRECISION AGRICULTURE, Warwick, 1997. Proceedings. Oxford: SCI, 1997. v.2. p.511-518. 
STAFFORD, J.V.; LEBARS, J.M.; AMBLER, B. A hand held data logger with integral GPS for producing weed maps by field walking. Computers and Electronics in Agriculture, v.14, n.2, p.235-247, Feb. 1996.

STAFFORD, J.V.; MILLER, P.C.H. Spatially variable treatment of weed patches. In: PRECISION AGRICULTURE, 3., Bloomington, 1996. Proceedings. Madison: ASA-CSSA-SSSA, 1996. p.465-474.

SUDDUTH, K.A; BORGELT, S.C.; HOU, J.X. Performance of a chemical injection sprayer system. Applied Engineering in Agriculture, v.11, n.3, p.343-348, May 1995.

THORNTON, P.K.; FAWCETT, R.H.; DENT, J.B.; PERKINS, T.J. Spatial weed distribution and economic threshold for weed control. Crop Protection, v.9, n.5, p.337-342, Oct. 1990.

TISDALE, S.L.; NELSON, W.L.; BEATON, J.D.; HAVIN, J.L. Soil fertility and fertilizers. 5.ed. New York: MacMillan, 1993. 615p.

VIEIRA, S.R. Geoestatística aplicada a agricultura de precisão. In: BORÉM, A.; GIÚDICE, M.P. del.; QUEIROZ, D.M. de; MANTOVANI, E.C.; FERREIRA, L.R.; VALLE, F.X.R. do; GOMIDE, R.L. (Ed.). Agricultura de precisão. Viçosa: UFV, 2000. cap.5, p.93-108.

VIEIRA, S.R. Uso da geoestatística em estudos de variabilidade espacial. In: CURSO DE ATUALIZAÇÃO EM CONSERVAÇÃO DO SOLO, $1995 . \quad$ Apostila. Campinas: IAC, 1995. $61 \mathrm{p}$.

VRINDTS, E.; BAERDEMAEKER, J. Optical discrimination of crop, weed and soil for on-line weed detection. In: PRECISION AGRICULTURE, Warwick, 1997. Proceedings. Oxford: SCI, 1997. v.2. p.537-544.

WALTER, A.M.; HEISEL, T.; CHISTENSEN. S. Shortcuts in weed mapping. In: PRECISION AGRICULTURE, Warwick, 1997. Proceedings. Oxford: SCI, 1997. v.2. p.777-784.

WARRICK, A.W.; MEYERS, D.E.; NIELSEN, D.R. Geostatistical methods applied to soil science. In: Klute, A. (Ed.). Methods of soil analysis. Madison: American Society Agronomy and Soil Science Society, 1986. cap.1, p.53-82. 
WHITE, J.G.; ZASOSKI, R.J. Mapping soil micronutrients. Field Crop Research, v.60, n.1, p.11-26, Jan. 1999.

WILLIAMS, M.M.; GERHARDS, R.; REICHART, S.; MORTENSEN, D.A.A; MARTIN, A.A.R. Weed seedling population responses to a method of site-specific weed management. In: PRECISION AGRICULTURE, 4., St. Paul, 1999. Proceedings. Madison: ASA-CSSA-SSSA, 1999. p.123-252.

YANG, C.; ANDERSON, G.L.; KING, J.H.; CHANDLER, E.K. Comparison of uniform and variable rate fertilization strategies using grid soil sampling, variable rate technology and yield monitoring. In: PRECISION AGRICULTURE, 4., St. Paul, 1999. Proceedings. Madison: ASA-CSSA-SSSA, 1999. p.675-685.

YANG, C.C.; PRASHER, S.O.; LANDRY, J.A. Development of weed maps in corn fields for precision farming. St. Joseph: ASAE, 1999. 16p. (ASAE Paper, 3044)

ZANIN, G.; BERTI, A.; RIELLO, L. Incorporation of weed spatial variability into the weed control decision-making process. Weed Research, v.38, n.2, p.107-118, Apr. 1998.

ZWIGGELAAR, R A review of spectral properties of plants and their potential use for crop/weed discrimination in row crops. Crop Protection, v.17, n.3, p.189-206, May 1998. 